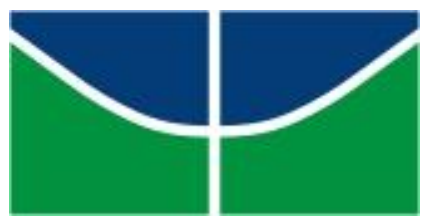

Universidade de Brasília

Faculdade de Educação- PPGE

ALCIONE MARQUES FERNANDES

LOUCEIRAS DE ARRAIAS: DO OLHAR ETNOMATEMÁTICO À ECOLOGIA DE SABERES NA UNIVERSIDADE FEDERAL DO TOCANTINS

Tese de Doutorado apresentado ao Programa de PósGraduação em Educação da FE/Universidade de Brasília - UnB, na área de concentração Educação e linha de pesquisa 6. Educação Ambiental e Educação do Campo (EAEC) como requisito parcial para obtenção do título de Doutora em Educação.

Orientadora: Prof ${ }^{a}$. Dra . Leila Chalub Martins

BRASÍLIA -DF

FEVEREIRO 2016 


\title{
LOUCEIRAS DE ARRAIAS: DO OLHAR ETNOMATEMÁTICO À ECOLOGIA DE SABERES NA UNIVERSIDADE FEDERAL DO TOCANTINS
}

Tese apresentada ao Programa de Pós-Graduação em Educação da Faculdade de Educação da Universidade de Brasília, na área de concentração em Educação Ambiental e Educação do Campo (EAEC) como requisito parcial para obtenção do título de Doutora em Educação.

Brasília, 23 de fevereiro de 2016.

\section{Banca Examinadora:}

\author{
$\operatorname{Prof}^{\mathrm{a}}$ Dr $^{\mathrm{a}}$ Leila Chalub Martins \\ Universidade de Brasília \\ (Orientadora)
}
Prof. Dr. Alan Kardec Martins Barbiero
Universidade Federal do Tocantins
(Membro)
Prof. Dr. José Ricardo e Sousa Mafra
Universidade Federal do Oeste do Pará
(Membro)
Prof. Dr. Elimar Pinheiro do Nascimento
Universidade de Brasília
(Membro)
Prof. Dr ${ }^{\mathrm{a}}$. Vera Margarida Lessa Catalão
Universidade de Brasília
(Membro)


Dedico este trabalho a Dona Pretinha e a Dona Andrelina pela expressão silenciosa de seus saberes tradicionais desvendado na arte de suas louças. 


\section{AGRADECIMENTOS}

Agradeço aos meus pais: Gabriel (in memorian) e Demézia que me doaram a vida e ensinaramme os marcos essenciais do caminho: o amor, o respeito, a tolerância, a gratidão e a dignidade. Agradeço aos caminhos que percorri em minha formação acadêmica e profissional, tortuosa e íngreme, composta por inúmeros desafios que em vários momentos me levaram a pensar em desistir de meus sonhos.

Agradeço aos meus professores que ao longo de minha formação me instigaram a pensar, quantificar, rememorar, indagar, questionar, qualificar, enfim buscar o conhecimento.

Agradeço a oportunidade que tive em ingressar como professora da Universidade Federal do Tocantins no momento em que ela se constituía institucionalmente, dessa forma pude vivenciar suas escolhas e seus caminhos, suas discussões e seus avanços. E agradeço em especial ao momento ímpar que presenciei nesta instituição: a realização do Seminário Internacional Distintos Olhares em 2009 com a presença do pensador contemporâneo Edgar Morin, naquela ocasião o meu pensamento passou por uma grande reforma conduzindo a busca pelo diálogo entre distintos saberes em objetivo central de minhas indagações.

Agradeço a minha orientadora e amiga Leila por acompanhar-me nesta trajetória, tornando possível a atualização de todos os diálogos.

Agradeço a minha família, meu esposo: Edmur e minhas filhas: Letícia e Tainã que durante estes quatro anos compartilharam minhas angústias e ajudaram-me a vencer o desânimo nas horas mais difíceis, iluminando sempre a minha caminhada. Agradeço ao carinho e dedicação de minha mãe, mesmo distante fisicamente se presente em todos os momentos.

Além disso, agradeço a colaboração especial de meu esposo Edmur e de minha filha Letícia no acompanhamento em minhas pesquisas de campo. E agradeço a Letícia e ao seu namorado Renan pelo registro fotográfico de vários momentos da minha pesquisa.

Agradeço aos meus amigos e amigas, pelo compartilhamento de ideias e de sonhos e também pelo simples fato de estarmos juntos na mesma correnteza, mesmo que fisicamente distantes: Adriana, Dinorá, Cláudia, Anelice, Deire, Rosana, Maria Paula e tantos outros que nem tenho como citar.

Enfim, agradeço pelo carinho com que fui acolhida pelas louceiras: Dona Pretinha de Dona Andrelina ao abrirem as portas de suas casas e me deixarem questionar sobre seus sab fazeres.

Obrigada! 
Não era usando como instrumentos nenhum de meus atributos que eu estava atingindo o misterioso fogo manso daquilo que é um plasma foi exatamente tirando de mim todos os atributos, e indo apenas com minhas entranhas vivas (Clarice Lispector, 1977). 


\section{RESUMO}

Esta pesquisa foi desenvolvida com as duas únicas louceiras do município de Arraias, estado de Tocantins, representantes de um conhecimento tradicional com características singulares desde o processo de construção geométrica das botijas, potes e gamelas até a ornamentação simétrica com argila colorida, envolvendo diferentes saberes em sua sistematização e execução, transmitido oralmente ao longo de gerações e agora ameaçado de extinção. A investigação foi baseada no registro etnográfico tendo como fundamento a Etnomatemática na perspectiva de Ubiratan D'Ambrósio e de Teresa Vergani, apontando para a inserção destes saberes no âmbito da Universidade Federal do Tocantins como prática da Ecologia de Saberes. Este estudo etnomatemático embasou a definição da matemática da sensibilidade como a convergência entre o pensamento matemático formal do pesquisador e a arte (e/ou técnica) desenvolvida por diferentes grupos ou sujeitos cognitivos nos seus fazeres e saberes tradicionais. Para a introdução destes saberes na universidade propõe-se incluir as louceiras de Arraias como extensionistas colaboradoras em projetos de extensão e no desenvolvimento de uma disciplina no curso de Licenciatura em Matemática do campus de Arraias, considerando que as raízes desta universidade foram estabelecidas na reforma de pensamento proposta por Edgar Morin, como apontam dois momentos ímpares por ela protagonizados: a avaliação das dimensões da sustentabilidade, interdisciplinaridade e inserção social realizada pelo Observatório Internacional da Reforma Universitária no período de 2008 a 2009 e o Seminário Internacional Distintos Olhares realizado em junho de 2009, sendo que a inserção da matemática da sensibilidade das louceiras de Arraias no ambiente acadêmico institui o resgate das propostas delineadas nestes dois eventos que refletem a busca pela religação dos saberes empreendida por esta universidade.

Palavras-Chave: Etnomatemática. Ecologia de Saberes. Matemática da Sensibilidade. Universidade Federal do Tocantins. Louceiras de Arraias. 


\begin{abstract}
This research was developed with the only two craftswomen from clay the municipality of Arraias, Tocantins state, representatives of traditional knowledge with unique characteristics from the geometric construction process of the bottles, jars and bowls to symmetrical ornamentation with colored clay, involving different areas of knowledge in systematization and execution, transmitted orally over generations and now threatened with extinction. The research was based on ethnographic record and is based upon the Ethnomathematics the perspective of Ubiratan D'Ambrosio and Teresa Vergani, pointing to the inclusion of this knowledge within the Federal University of Tocantins and practice of Knowledge Ecology. This ethnomathematical study based the sensitivity mathematical definition as the convergence between formal mathematical thinking of the researcher and the art (and / or technical) developed by different groups or cognitive subject in their doings and traditional knowledge. For the introduction of this knowledge in the university proposes to include louceiras Arraias as extension cooperating in extension projects and the development of a discipline in the Bachelor's Degree in Arraias campus Mathematics, considering that the roots of this university were established in the reform thinking proposed by Edgar Morin, as shown two odd moments for her perpetrated: assessing the dimensions of sustainability, interdisciplinarity and social integration conducted by the International Centre for University Reform from 2008 to 2009 and the International Seminar Distinguished looks held in June 2009 , and the mathematics of insertion of the sensitivity of Arraias of craftswomen from clay in academia establishing the redemption of the proposals outlined in these two events that reflect the search for reconnection of knowledge undertaken by this university.
\end{abstract}

KEYWORDS : Ethnomathematics. Ecology of Knowledge Traditional knowledge. Sensitivity of Mathematics. Federal University of Tocantins. Craftswomen from clay for Arraias. 


\section{ÍNDICE DE FIGURAS}

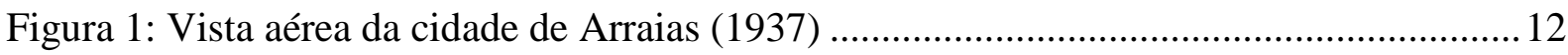

Figura 2: Mural histórico na Praça Matriz de Arraias ........................................................... 18

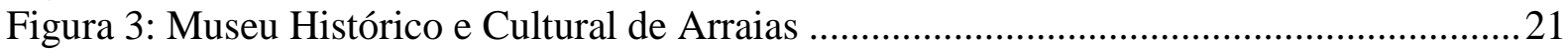

Figura 4: Localização do município de Arraias no Estado de Tocantins .................................27

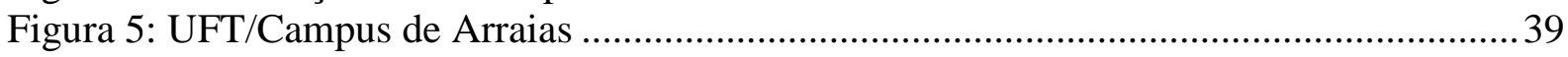

Figura 6: Mapa do Tocantins/Localização dos campi da UFT nas regiões do Estado ............. 43

Figura 7: Abertura oficial do Seminário Internacional Distintos Olhares na UFT/ Palmas,

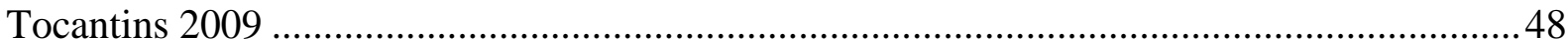

Figura 8 Outorga de título Doutor Honoris Causa ao pensador Edgar Morin e à quebradeira de

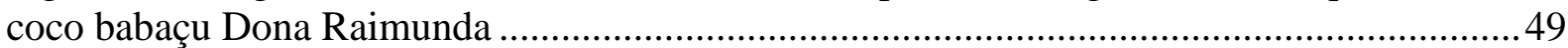

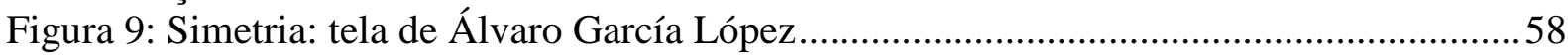

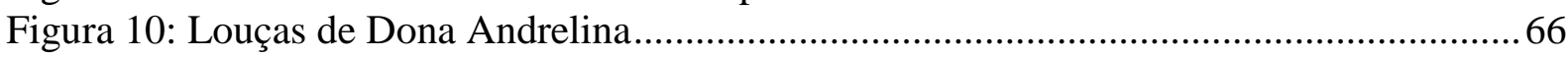

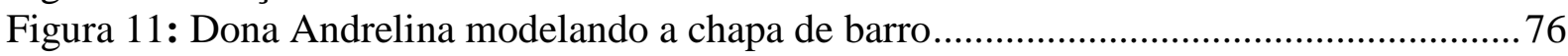

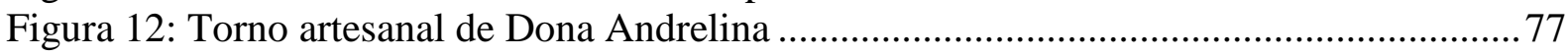

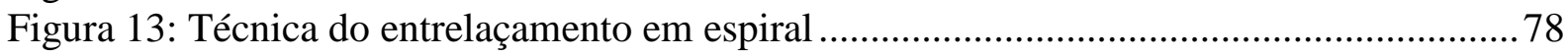

Figura 14: Processo de secagem das louças ao sol ............................................................... 79

Figura 15: Pintura das louças com argila colorida por Dona Pretinha, utilizando o pincel de

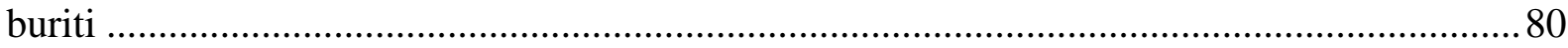

Figura 16: Louças de Dona Andrelina pintadas aguardando o processo de queima ................ 80

Figura 17: Forno para queima de louças fabricado por Dona Pretinha .................................... 83

Figura 18: Prateleira de madeira com as louças de Dona Pretinha na TO 050 ....................... 84

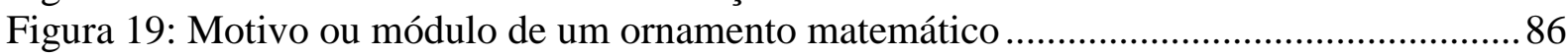

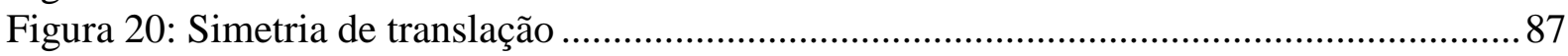

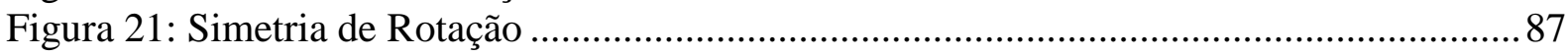

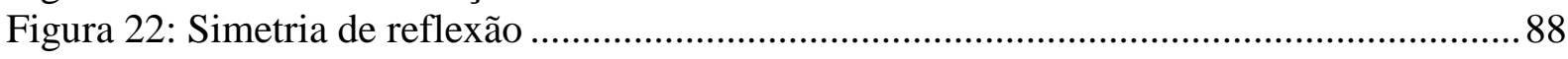

Figura 23: Louça de Dona Andrelina com tema se repetindo entre duas linhas paralelas (faixa

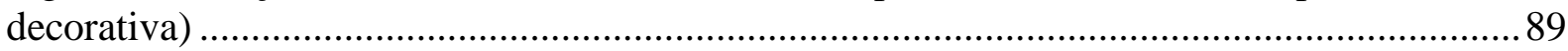

Figura 24: Botija de Dona Andrelina com ornamento de faixa decorativa ............................. 90

Figura 25: Botija no formato de abóbora com ornamento do tipo mosaico .............................90

Figura 26: Botija com ornamento do tipo roseta .................................................................. 91

Figura 27: Produção de potes e botijas de Dona Andrelina em setembro de 2014 ..................99

Figura 28: Produção de louças para os festejos de setembro de 2015 .................................. 131

Figura 29: Técnica de entrelaçamento em espiral na confecção das louças........................... 131

Figura 30: Dona Andrelina modelando uma botija .......................................................... 132

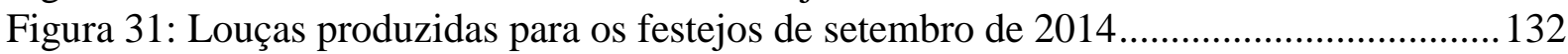

Figura 32: Dona Pretinha usando o processo de enformar o pote ....................................... 133

Figura 33: Pintura com argila colorida utilizando os dedos ............................................... 133

Figura 34: Residência de Dona Pretinha: Sítio Novo (zona rural de Arraias/TO) ................. 134

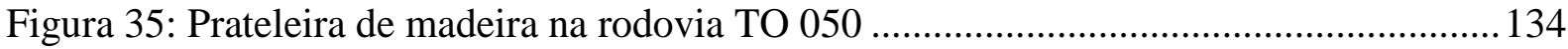




\section{ÍNDICE DE SIGLAS}

CDS - Centro de Desenvolvimento Sustentável

CEPPIR - Comissão especial de política de promoção de igualdade racial

CESPE - Centro de seleção e promoção de eventos da UnB

CLAEH - Centro latino-americano de Economia Humana

CONSEPE - Conselho de Ensino, pesquisa e extensão

CONSUNI - Conselho Universitário

CSA - Comissão Setorial de Avaliação

DF - Distrito Federal

EHESS - École de Hautes Etudes em Sciences Sociales

EJA - Educação de jovens e adultos

FCT - Fundação cultural do Tocantins

FUNAI - Fundação Nacional do índio

IBGE - Instituto Brasileiro de Geografia e Estatística

IIRPC - Instituto Internacional de pesquisa sobre política civilizacional

IPHAN - Instituto do Patrimônio Histórico e Artístico Nacional

INSS - Instituto nacional da seguridade social

NEAI - Núcleo de assuntos e estudos indígenas

NEDETUR - Núcleo de estudos para o desenvolvimento do turismo sustentável do sudeste tocantinense

NUTA - Núcleo Tocantinense de Arqueologia da Fundação Universidade do Tocantins

ORUS - Observatório Internacional da reforma universitária

PCECA - Projeto de Consolidação e expansão do campus de Arraias

PIMI - Programa de monitoria indígena

PNAES - Programa Nacional de assistência estudantil

PPC - Projeto Pedagógico de curso

PROEST - Pró- Reitoria de assuntos estudantis

TO - Tocantins

UAB - Universidade aberta do Brasil

UFPB - Universidade Federal da Paraíba

UFT - Universidade Federal do Tocantins

UnB - Universidade de Brasília

UNITINS - Fundação Universidade do Tocantins 
SUMÁRIO

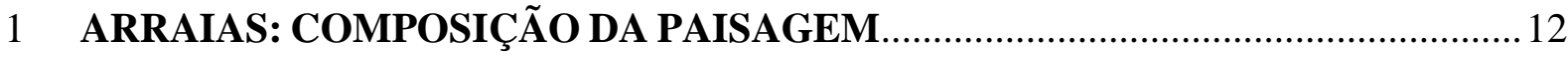

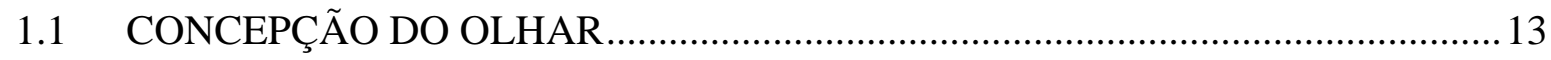

1.2 ARRAIAS: OS RETALHOS DA HISTÓRIA …................................................ 15

1.3 TRADIÇÃO E MODERNIZAÇÃO: A DICOTOMIA DO PRESENTE ................. 18

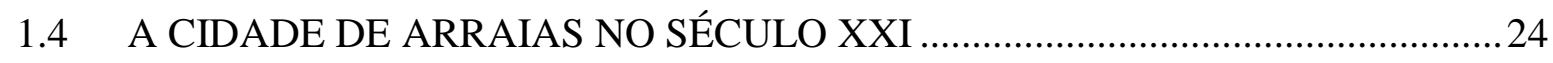

1.5 LAGOA DA PEDRA E KALUNGA MIMOSO: AS COMUNIDADES RURAIS

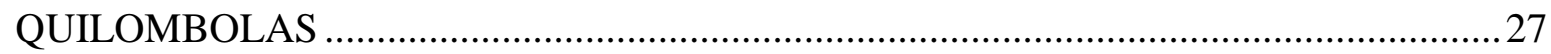

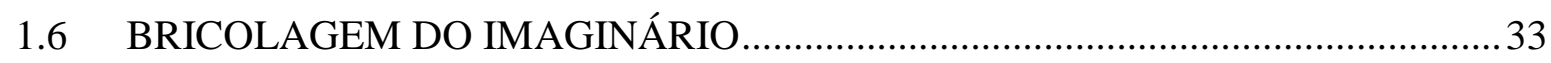

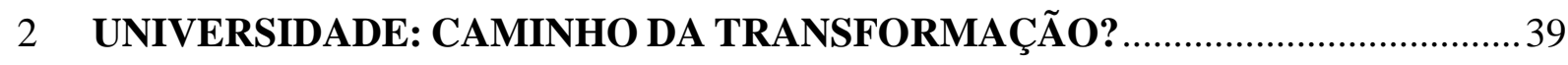

2.1 A REFORMA PARADIGMÁTICA DA UNIVERSIDADE .................................40

2.2 A UNIVERSIDADE FEDERAL DO TOCANTINS E A PROPOSTA DE REFORMA DO PENSAMENTO

2.3 AS DIMENSÕES DA UNIVERSIDADE FEDERAL DO TOCANTINS EM ANÁLISE

2.4 SEMINÁRIO INTERNACIONAL: ENCONTRO DOS DISTINTOS OLHARES.. 47

2.5 A INSERÇÃO SOCIAL NO COTIDIANO DA UFT .............................................50

2.6 CAMPUS DE ARRAIAS: O OLHAR EM PERSPECTIVA ...................................53

3 AS LENTES TEÓRICAS DE MEU OLHAR: ECOLOGIA DE SABERES E

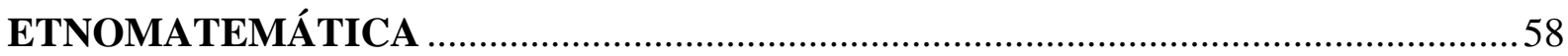

3.1 O OLHAR RECOBERTO (OU DESCOBERTO) PELAS LENTES TEÓRICAS ... 59

3.2 ECOLOGIA DE SABERES: INSTITUCIONALIZAÇÃO DOS SABERES

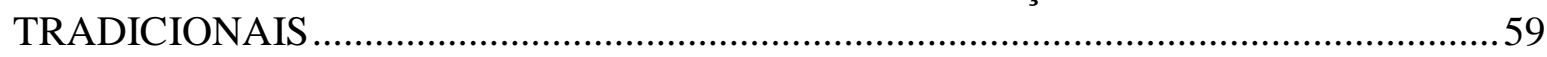

3.3 ETNOMATEMÁTICA: A GRAMÁTICA DAS FORMAS DE VIDA....................61

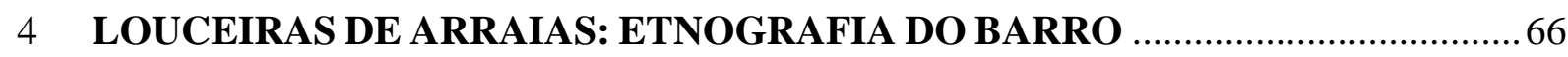

4.1 OLHAR ETNOGRÁFICO: A BUSCA PELO SIGNIFICADO...............................67

4.2 AS LOUCEIRAS DE ARRAIAS: HISTÓRIAS DE VIDA ENTRELAÇADAS AO BARRO . .68

4.3 ARTESANATO: LINGUAGEM DE FORMAS DE ESPAÇO ANCORADA NOS

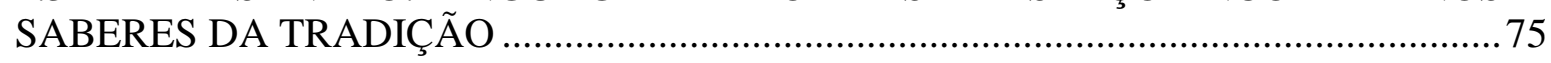

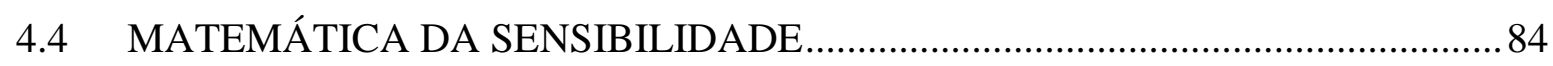

4.5 MITOLOGIA DAS MULHERES DO BARRO .................................................. 91

4.6 ECOLOGIA DE SABERES: O DIÁLOGO ENTRE A FORMA E O OLHAR .......93

5 CONSTRUINDO PONTES ENTRE A MATEMÁTICA SENSÍVEL DO BARRO E

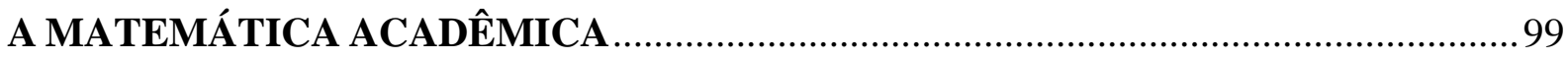

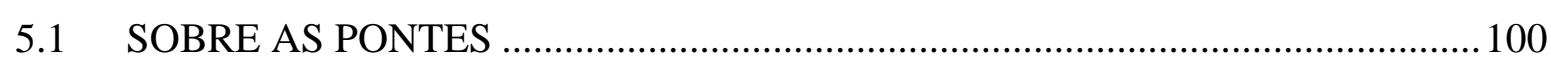

5.2 BASES PARA A CONSTRUÇÃO DA PROPOSTA DE DISCIPLINA................. 101

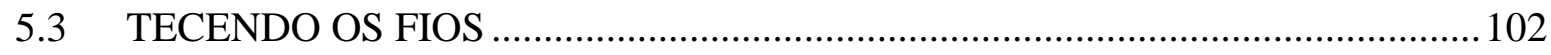




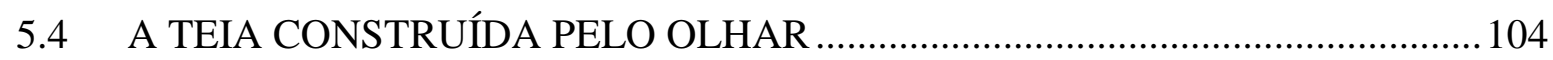

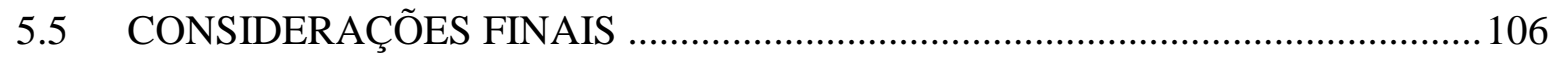

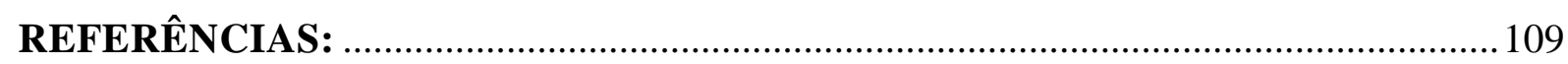

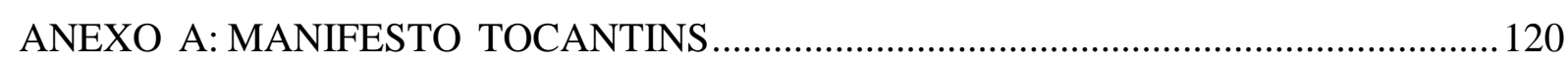

ANEXO B: REGISTRO DE IMPRESSÕES SOBRE O SEMINÁRIO INTERNACIONAL

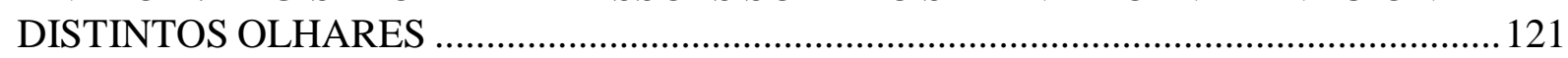

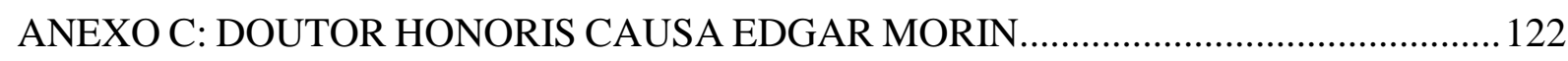

ANEXO D: DOUTOR HONORIS CAUSA DONA RAIMUNDA ......................................... 123

ANEXO E: RESOLUÇÃO CONSUNI SISTEMA DE COTAS PARA QUILOMBOLAS .. 124

ANEXO F: RESOLUÇÃO CONSEPE SISTEMA DE COTAS INDÍGENAS ......................126

ANEXO G: REGULAMENTAÇÃO DAS ATIVIDADES DO EXTENSIONISTA

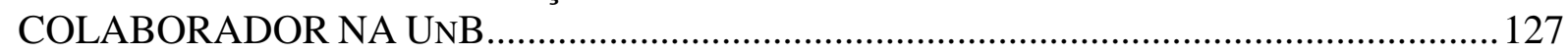

APÊNDICE I: AS INSTÂNCIAS DO OLHAR ............................................................130

APÊNDICE II: EMENTA DE PROPOSTA DE DISCIPLINA …………………………….....135 


\section{ARRAIAS: COMPOSIÇÃO DA PAISAGEM}

Figura 1: Vista aérea da cidade de Arraias (1937)

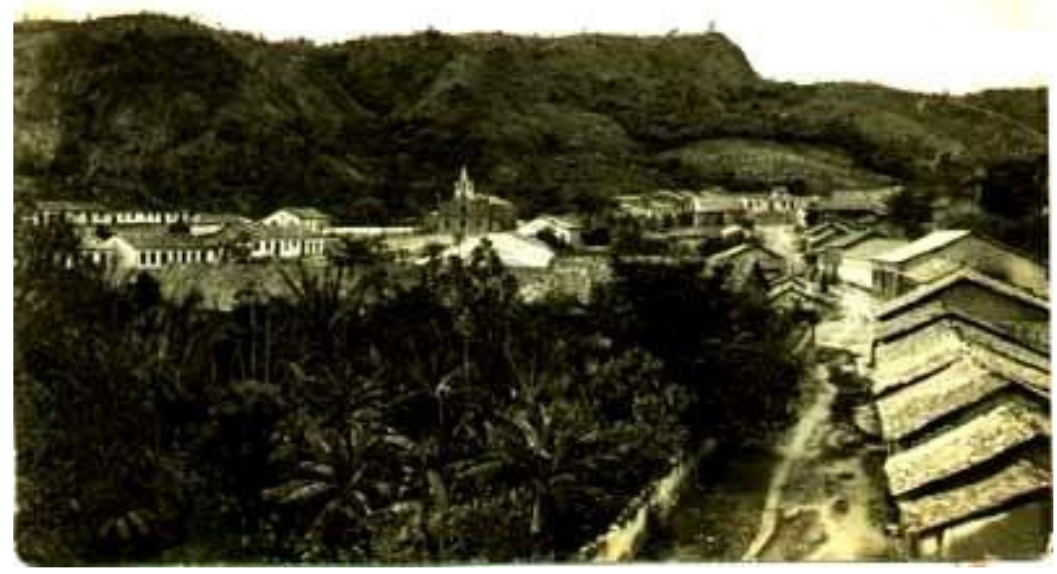

Fonte: Site da ONG Vivaarraias ${ }^{1}$

"Há uma história cosmológica, no interior da qual há uma história da matéria, no interior da qual há uma história de vida, na qual há finalmente nossa própria história" (Ilya Prigogine, 2002)

${ }^{1}$ Disponível em http://www.vivaarraias.org.br. Acesso em 25 set. 2010. 


\subsection{CONCEPÇÃO DO OLHAR}

No pensamento complexo existe um princípio basilar na constituição da investigação científica, a recuperação da importância do sujeito cognoscente no processo de conhecimento, ou seja, o sujeito e o objeto vivem uma relação de reciprocidade na dimensão do conhecimento segundo Morin (1999, p. 30) “[...] encarar o problema complexo em que o sujeito cognoscente, permanecendo sujeito, torna-se objeto do seu conhecimento". Dessa forma pode-se definir um processo harmônico entre o desvelamento do campo de pesquisa e a capacidade do pesquisador em se colocar como sujeito, observador participante, vivendo um processo relacional intenso com a produção de saberes que se estabelece. Esta reciprocidade torna o pesquisador implicado com sua pesquisa de forma a ser considerado membro, como sugerido por Roberto Macedo:

O membro, aquele que domina a linguagem natural, conforme define a etnometodologia é o ator/autor que (co)define sua pergunta de pesquisa em função de sua inserção social, dos seus pertencimentos, dos seus desafios históricos, define também sua meta a partir dessa perspectiva (MACEDO, 2012, p.45).

Meu campo de pesquisa foi nascendo num processo lento, quase como um parto não programado, apenas intuído a partir de experiências que foram construídas ao longo de minha trajetória acadêmica, e também pelas experiências vividas por outras percepções, como o olhar (FERNANDES; CHALUB MARTINS, 2014, p. 483).

O olhar aqui toma proporções de convergência entre as distintas percepções, como dito por Novaes (1988, p. 13): “Criamos dicotomias permanentes: a consciência e a coisa, o sujeito e o objeto - divisões brutais que determinam com rigor as esferas do sensível e do pensado, do que vê e do que é visto", este olhar é da sensibilidade e do pensamento, sendo capaz de proporcionar a inserção do sujeito cognoscente em seu objeto de conhecimento, contrariando o que a ciência em séculos de existência afirma a respeito da ilusão do mundo sensorial.

Ao chegar a Arraias (Tocantins) trilhando a TO 050 sentido Brasília (DF) /Tocantins deparei-me com o artesanato de barro branco às margens da rodovia, numa prateleira de madeira em frente à casa de Dona Pretinha. Muitas e muitas vezes fiz este percurso, olhei aquele artesanato de beleza ímpar e apenas o apreciei como paisagem.

Karina Dias (2010) aborda em seu livro o interior do olhar como uma paisagem labiríntica alternando-se entre o visto e o não visto, afirmando que: "A experiência da paisagem no cotidiano se forja, então, na junção entre uma maneira de olhar e os espaços percorridos" (Dias, 2010, p. 113). O que é visto torna-se algo quase invisível, como se o ato de olhar 
continuamente não permitisse enxergar a realidade. A autora questiona: "Como então interromper, mesmo que momentaneamente, nossa percepção visual rotineira para que se instale uma percepção inusitada?" (2010, p.113).

Experimentar a paisagem cotidiana pode ser encontrar novos pontos de vista como elos que se aproximariam e se distanciariam. A possibilidade que se apresenta é a noção do $i n v u^{2}, o$ n[ã]o-visto: “[...]é se dar conta de que vemos e, de que, acima de tudo, não vemos; de que, na rotina, experimentamos frequentemente um estado de cegueira" (DIAS, 2010, p.115).

O movimento do olhar pode ser compreendido por meio de três instâncias: ver, olhar e ter visto. O primeiro movimento é representado por um sobrevoo, como se neste momento quiséssemos captar tudo o que nossa vista alcança, são os olhos faróis de Platão. O olhar é intencional, ele se atém ao que lhe clama conhecimento, toda sua intencionalidade está ligada à focalização. Por fim, o terceiro movimento: ter visto é uma pausa, quando se analisa o que foi visto, armazena-se o instantâneo e liga-se diretamente à memória. Estas três instâncias do movimento do olhar não são hierarquizadas, não possuem tempo determinado para acontecerem, são instâncias flexíveis e dão sentido ao que se apresenta a nós (DIAS, 2010).

O movimento do olhar acontece a todo instante e segundo Karina Dias são: “Instâncias móveis, flexíveis e inesperadas, enraizadas no corpo e no espaço, na carne do mundo, como pensa Merleau-Ponty, esse lugar onde se entrelaçam o corpo vidente e o corpo visível" (DIAS, 2010, p.206).

Meu contato com a produção artesanal de cerâmica de barro branco às margens da TO 050 no município de Arraias, Tocantins, foi construído como olhar-em-paisagem. Inicialmente apenas vi, sobrevoei a paisagem rústica e tranquila daquela propriedade rural estabelecida numa rodovia de pouco tráfego, na prateleira de madeira em frente à cerca vários potes e botijas sendo oferecidos aos viajantes que por ali trafegam (FERNANDES; CHALUB-MARTINS, 2014, p. 484).

Lentamente, ao conhecer a história de vida daquela mulher artesã, comecei a olhar a cerâmica de modo completamente novo, despertou-me interesse pela forma como são produzidas as peças e de como esta técnica tão rudimentar conservou-se ao longo de anos. Este despertar aconteceu em parte por causa de meu contato com a Etnomatemática, que torna possível a ponte entre a Matemática e a Antropologia (D’Ambrosio, 2009). Como também em virtude de questões de vida que foram se tornando questões de pesquisa: Qual é o conhecimento dessa mulher artesã que é da ordem da etnomatemática? Como esse conhecimento opera? Como

\footnotetext{
${ }^{2} \mathrm{O}$ termo francês invu ainda não consta nos dicionários, mas seu uso aproxima-se do significado de não-visto, como negação, remetendo ao que ainda não foi visto anteriormente (DIAS, 2010).
} 
é transmitido e atualizado? Existe alguma evidência de diálogo desse conhecimento etnomatemático e o conhecimento escolarizado? Este foi o movimento de olhar intencional clamando pelo conhecimento.

Na concepção desse olhar existe latente uma aproximação com a intuição, no sentido destacado por Lebrun (1988, p. 21): “[...] é a palavra intuição a que melhor exprime a osmose entre visão e conhecimento", sendo a responsável por abarcar a multiplicidade das formas, das cores, das espécies com um só olhar e estabelecer suas conexões, tomando como base o significado do termo dialética em Platão. Por meio dessa intuição que através do olhar busca o conhecimento, iniciei a construção do olhar-em-paisagem, buscando o invu que poderia aqui ser comparado a luz que clareia o que ainda não foi visto, o oculto e nesse caminho percorro: “[...] zonas sombreadas da visão, o informe, a escuridão da noite e a nebulosidade da bruma" (DIAS, 2010, p.116).

$\mathrm{Na}$ construção deste olhar-em-paisagem, com raízes fincadas na intuição como imbricamento entre visão e conhecimento, faz-se necessário conhecer o contex to onde a história de Dona Pretinha e de Dona Andrelina, também artesã do barro, estão inseridas: a cidade de Arraias.

\subsection{ARRAIAS: OS RETALHOS DA HISTÓRIA}

Arraias é uma das cidades mais antigas do estado de Tocantins, criado a partir do desmembramento do norte de Goiás, filho mais novo da federação brasileira, que nasceu com a Constituição de 1988 e instalou-se efetivamente em 1989 (SILVA, N., 2008). O estado de Tocantins localiza-se na região Norte e faz divisa com os estados de Maranhã, Pará, Bahia, Piauí, Mato Grosso e Goiás.

A cidade de Arraias localiza-se na região sudeste do estado, distante $420 \mathrm{~km}$ da capital do estado: Palmas, limita-se ao norte com os municípios de Conceição do Tocantins, Taipas e Taguatinga; ao sul faz divisa com Campos Belos, no estado de Goiás; a oeste com o município de Paranã e a leste com as cidades de Novo Alegre, Combinado e Aurora do Tocantins. Seu clima tropical úmido possui as estações de seca e de chuva divididas ao longo do ano, seu relevo acidentado rendeu-lhe o codinome de "Cidade das Colinas", por estar situada em meio a muitos morros, também é praticamente cercada pelas ruínas dos muros de pedras construídos pelos escravos. 
Esta região, antigo norte de Goiás e atual estado do Tocantins, em seu processo de povoamento, entre os séculos XVII e XVIII, foi devassada por sertanistas, missionários e criadores de gado, vindos do Pernambuco, Bahia e Piauí. Segundo a historiadora Apolinário (2007) a influência da sociedade escravista instituída em Arraias teve um papel relevante na constituição social dessa região.

\begin{abstract}
Na formação da paisagem social da região norte da capitania de Goiás, destacaram-se diversas situações matizadas por padrões de comportamento fincados no escravismo. Sua sociedade vivia no rastro dos índios, na tentativa constante de subjugá-los em aldeamentos, e da exploração do "suor" dos negros, na busca do precioso metal. Na composição dessa paisagem social, estava a sociedade escravista de um dos principais núcleos de povoamento dessa região: o arraial de Arraias (APOLINÁRIO, 2007, p.135)
\end{abstract}

A cidade de Arraias estende suas raízes históricas no passado da escravidão marcado pela descoberta do ouro em seus limites, sua história antiga, com mais de 270 anos é marcada pela luta e pela resistência do povo africano escravizado que representa um dos troncos de onde se originou a sua população. A cidade contornada em vários trechos por antigos muros de pedras nasceu na Chapada dos Negros como garimpo de ouro, vestígios desse arraial aurífero ainda são encontrados nas trilhas da chapada: a casa do quinto, a ponte, a igrejinha, todas construções feitas de pedra, hoje em ruínas, são testemunhas silenciosas de um passado de riquezas, mas principalmente de tristeza e de dor. "O arraial de Arraias teve o ouro como móvel, e sua primitiva povoação formou-se nas adjacências de um rico filão de ouro, que ficava situado no alto da Chapada dos Negros" (APOLINÁRIO, 2007, p. 76).

A população do antigo arraial deslocou-se da Chapada e fixou-se num sítio acidentado próximo ao local das minas de ouro, em 1740. “[...] D. Luís de Mascarenhas chega a Arraias e ordena a transferência da população que vivia na Chapada dos Negros para uma outra área um pouco mais distante das minas" (APOLINÁRIO, 2007, p. 77).

Neste local a cidade de Arraias fincou suas raízes, construiu suas casas, modelou suas ruas tortuosas acompanhando as condições topográficas, instalou suas igrejas, ergueu casarões, enfim escreveu ao longo do tempo sua história e a sua cultura foi nutrida sob a influência do branco, do negro e do índio.

Antes de ser ocupado por aventureiros ávidos de lucros, o território setentrional goiano era habitado pelos povos indígenas na sua maioria pertencentes ao tronco linguístico Macro-Jê entre os quais destacam-se os Akroá, Xakriabá, Xavante, Xerente, Krahô, Apinayé, Javaé, Xambioá e Karajá (APOLINÁRIO, 2007, p. 68) 
O período de prosperidade das minas de ouro de Arraias não foi muito longo, ao final da segunda metade do século XVIII, as minas aluviais esgotaram-se e iniciou-se o período de desenvolvimento da pecuária e da agricultura. Arraias conseguiu estabelecer-se mudando sua atividade econômica: “com a queda da mineração, os proprietários de minas, visando à própria sobrevivência, passaram à criação de gado bovino, descendo das serranias para as quebradas de boa vegetação, onde fixaram suas fazendas" (Cordeiro, 1989, p. 22), porém tais mudanças causaram transtornos e desgastes em sua população, inclusive pela perda progressiva de influência política.

O povoado de Arraias inicialmente foi elevado a julgado, pelo ato governamental de 16 de agosto de 1807, em 3 de fevereiro de 1834 passou a categoria de Vila, por alguns anos a Vila de Arraias perdeu sua sede municipal que foi transferida para o arraial de Santo Antônio do Morro do Chapéu (atual município de Monte Alegre de Goiás) sendo que em 1861 restaurouse a sua sede e finalmente em $1^{\circ}$ de agosto de 1914 galgou a condição de município (CORDEIRO, 1989).

A importância histórico-social desse antigo arraial com o passar dos anos e das décadas foi diminuindo como os limites do município. Arraias em sua posição de destaque regional estendia-se até o arraial de Santo Antônio do Morro do Chapéu, atual município de Monte Alegre de Goiás, sendo que Campos Belos, no estado de Goiás, Novo Alegre e Combinado, ambos em Tocantins compunham seu território constituídos como seus distritos. "Em 1911, o município de Arraias possuía apenas o distrito sede. O de Campos Belos foi incorporado ao município de Chapéu” (Cordeiro, 1989, p. 23). E os distritos de Combinado e de Novo Alegre foram emancipados em 1989 e 1993, respectivamente. Os limites do município foi estabelecendo as atuais delimitações e a pequena cidade, herdeira da miscigenação de raças, palco de uma sociedade fragilmente mineradora (Apolinário, 2007) constituiu-se da forma como está na atualidade: sede municipal, povoado de Mimoso e distrito de Canabrava (COSTA, 2008, p.134).

No centro de Arraias, na Praça Coronel Joaquim Lucena em frente à Igreja de Nossa Senhora dos Remédios, existe um grande painel histórico, todo pintado em azulejo criado pela artista plástica Maria Guilhermina Gonçalves Fernandes ${ }^{3}$ em 1969, contando o ciclo evolutivo histórico da cidade. Este ciclo evolutivo é descrito em quatro momentos: 1735: a descoberta e a corrida do ouro, 1800: criação de gado curraleiro e de gado zebu, o terceiro ciclo inicia-se com a chegada das irmãs dominicanas para conduzirem o Instituto Nossa Senhora de Lourdes

\footnotetext{
${ }^{3}$ Escultora renomada, doutora em Escultura pela Universidade de Paris e professora titular da Federal de Goiás (COSTA, 2008).
} 
em 1901 e por fim o último e quarto ciclo inicia-se com a implantação da energia elétrica em 1940 e o desenvolvimento da pecuária (ALMANAQUE..., 2001, p. 13).

Figura 2: Mural histórico na Praça Matriz de Arraias

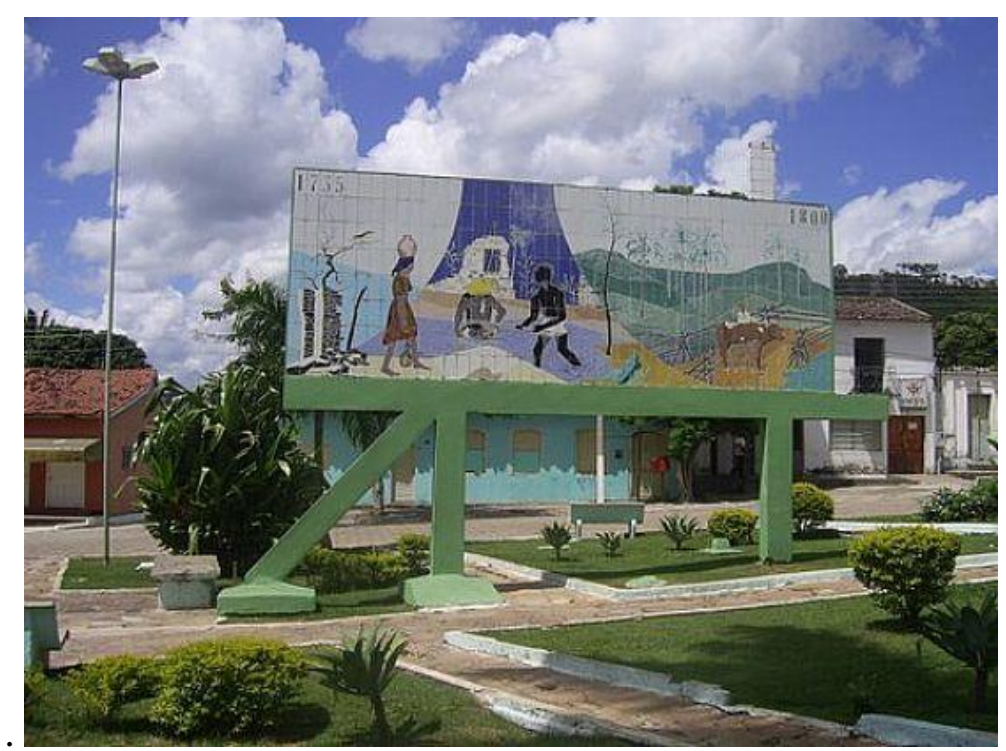

Fonte: Site de busca na internet ${ }^{4}$

\subsection{TRADIÇÃO E MODERNIZAÇÃO: A DICOTOMIA DO PRESENTE}

Atualmente, Arraias é uma cidade de interior, tranquila, pacata, conservando vestígios de seu passado secular, com os antigos casarões do centro da cidade, em sua maioria descaracterizados, o que certamente impede qualquer tipo de tombamento histórico. As ruas do centro calçadas por blocos de cimento, no formato de paralelepípedos, denominados de "bloquetes", fazem uma imitação do antigo calçamento de pedra presente até a alguns anos atrás: "Naquele tempo 1966 (grifo nosso), Arraias era bem organizada, arborizada e razoavelmente limpa, as ruas eram calçadas em pedra, havia muitas casas antigas e, claro, uma imponente igreja [...]" (SANTOS, R., 2002, p.30).

Arraias perdeu muito do seu patrimônio, praticamente quase $100 \%$. Eu ainda me lembro dessas ruas todas calçadas em pedra e aí foram tirando, foram tirando [...]Depois derrubaram as casas históricas que tinha, conservando-se uma ou outra, perdeu-se todo um patrimônio. Foram construindo casas mais modernas e perdeu-se todo um patrimônio arquitetônico, toda uma história [...] (trecho da entrevista do Padre Joaquim Misael da Silva) (PEDREIRA et al, 2012, p.100).

\footnotetext{
${ }^{4}$ Disponível em: http://www.ferias.tur.br/fotogr/88134/muralnapraca-fotoscaravonati/arraias/. Acesso em 16 nov. 2015.
} 
Este processo de deterioração do patrimônio histórico é marcado pelas transformações socioeconômicas características do mundo contemporâneo, conforme Pedreira et al. (2012, p.98) salienta:

\begin{abstract}
Apesar da importância da memória e dos lugares de memória na estruturação das identidades socioculturais locais, é consenso entre os estudiosos dessa temática que ao longo dos anos, a estruturação do capitalismo trouxe suas influências sobre essas dinâmicas culturais, provocando ressignificações nas organizações sociais e culturais das mais variadas populações.
\end{abstract}

Os lugares de memória são locais materiais, simbólicos e funcionais, dotados da capacidade de cristalizar as lembranças de um grupo que pode ser familiar, social, étnico proporcionando seu reconhecimento, seu encontro (Horta, 2015). O simbolismo presente nos lugares de memória remete à relação estabelecida por Castoriadis (1982, p. 154) entre o simbólico e o imaginário: "mas também, inversamente, o simbolismo pressupõe a capacidade imaginária. Pois pressupõe a capacidade de ver em uma coisa o que ela não é, de vê-la diferente do que é”. Os casarões antigos com as iniciais dos patriarcas das famílias e o ano de construção estampado em suas soleiras é um símbolo carregado de significação, assim como a organização espacial da igreja matriz em que os bancos possuem uma placa com a inscrição dos sobrenomes das famílias que os doaram.

As antigas edificações de Arraias, que em seu conjunto poderiam se constituir em lugares de memória, ao longo dos anos e décadas foram perdendo suas estruturas materiais, sua funcionalidade e, portanto, deixando de existir simbolicamente na imaginação de seus habitantes. Muitas vezes as edificações antigas são demolidas para cederem lugar a construções mais modernas ou então simplesmente relegadas ao esquecimento acabam se transformando em ruínas, como é o caso das construções de pedras da Chapada dos Negros. Em Arraias os antigos casarões possuem três destinos possíveis: são modificados perdendo suas características originais, demolidos ou simplesmente deixados ao sabor do tempo, acabando em ruínas, apenas alguns deles são recuperados, como o casarão que sedia o Museu Histórico e Cultural de Arraias.

O Museu tem história recente, fruto dos contrastes dessa cidade singular, onde a tradição muitas vezes não preserva a história, mas congela valores simbólicos, como o sobrenome das famílias nos bancos da igreja matriz, expresso na relação entre a instituição e o imaginário: "Não podemos fixar nem o grau geral de simbolização, variável segundo as culturas, nem os fatores que fazem com que a simbolização se exerça com intensidade particular sobre tal aspecto da vida da sociedade considerada" (CASTORIADIS, 1982, p. 150). 
O casarão onde o Museu instalou-se foi adquirido pela Fundação Cultural do Tocantins (FCT) e passou em 2009 pelo processo de restauração e adequação por meio de recursos da $14^{\circ}$ Superintendência Regional do IPHAN - Instituto do Patrimônio Histórico e Artístico Nacional. Oficialmente inaugurado em agosto de 2013, seu acervo permanente conta a história da fundação da cidade e da constituição dos quilombos, além de guardar documentos e fotos da passagem da Coluna Prestes pelo município, ainda oferece exposições temporárias de temas relevantes como o carnaval com o entrudo, a capoeira, entre outros.

O entrudo ${ }^{5}$ é uma tradição carnavalesca oriunda de Portugal que se desenvolveu nas ilhas de Cabo Verde e da Madeira, segundo Costa (2008, p. 202) e surgiu na cidade de Arraias provavelmente por herança portuguesa criando raízes e permanecendo ao longo dos anos. Com o intuito de preservar a cultura do carnaval de rua foi criada a Associação Amigos do Entrudo em maio de 2006, responsável pelo planejamento do itinerário nas ruas tortuosas da cidade, durante os 4 dias de festa. A saída dos foliões acontece normalmente a partir das 8 horas da manhã e o grupo percorre as ruas da cidade com parada para o almoço em uma residência previamente combinada. Os foliões seguem pelas ruas acompanhados da banda de músicos tocando antigas marchinhas de carnaval e com os baldes cheios de água vão molhando as pessoas pelo caminho e as convidando para a folia. Ao final da tarde todos se aglomeram na praça da matriz para dançar e brincar ao som de um trio elétrico.

\footnotetext{
${ }^{5}$ Festa popular que acontecia nesses dias, em que os brincantes trocavam pelas ruas arremessos de baldes de água, limões de cheiro, ovos, tangerinas, pastelões, luvas cheias de areia, esbordoavam-se com vassouras e colheres de pau, sujavam-se com farinha, gesso, tinta etc. [O folguedo vigorou até 1817 em Portugal e entrou em declínio no Brasil em 1854, por repressão policial, dando lugar ao moderno carnaval] . Disponível em http://houaiss.uol.com.br/busca?palavra=entrudo. Acesso em 20 nov. 2015.
} 
Figura 3: Museu Histórico e Cultural de Arraias

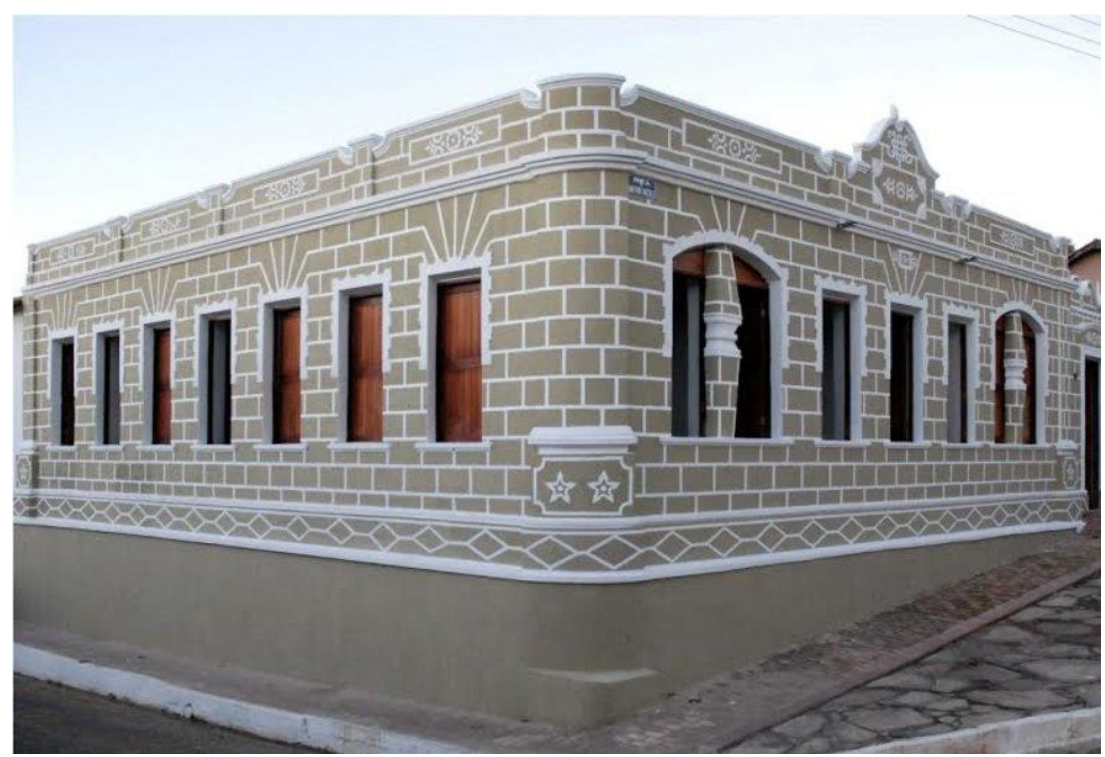

Fonte: Site de busca na internet ${ }^{6}$

Em quase trezentos anos de história a pequena cidade de pouco mais de 10.000 habitantes (Instituto Brasileiro de Geografia e Estatística, 2015) vive a contradição entre a preservação e a destruição de seu passado, muitas construções seculares encontram-se em péssimas condições de conservação ou já foram destruídas, como a antiga igrejinha do Rosário que existe apenas na memória dos antigos moradores:

Ficávamos ali naquela sombra mais um pouquinho olhando a Igreja Nossa Senhora do Rosário, já em ruínas se desfazendo ao passar do tempo, e o nosso coração ficava partido por observar aquele templo sagrado, tão bonito e majestoso, sendo destruído e ruído pelos anos, servindo como morada de morcegos e uma insana senhora, a Tiadorinha (RAMALHO, 2012, p.59).

Segundo Costa (2008, p. 144) as primeiras igrejas construídas no município foram as de São Benedito e de Nossa Senhora do Rosário: "Dizem que escravos recém-chegados construíram as igrejas de São Benedito e de Nossa Senhora do Rosário, buscando nelas a mediação divina para aplacar seu cotidiano de penúrias e servidão". Da igreja de São Benedito quase nada se sabe, não existe nenhum registro e nem mesmo as ruínas sobreviveram, da igreja de Nossa Senhora do Rosário, demolida para cumprir as exigências de uma médica, moradora local, restou apenas uma tela pintada pela escritora Rosolinda Batista de Abreu Cordeiro (COSTA, 2008, p. 145).

\footnotetext{
${ }^{6}$ Disponível em:

<https://www.google.com.br/search?q=museu+hist\%C3\%B3rico+e+cultural+de+arraias+to\&source=lnms\&tbm =isch\&sa=X\&ved=0ahUKEwjCtLbd1M_KAhUKHpAKHfknDBoQ_AUICSgD\&biw=1366\&bih=667\#imgrc=U CWJ19sdU5dQeM\%3A>. Acesso em 15 out. 2015.
} 
A Igreja de Nossa Senhora dos Remédios, ocupando posição de destaque na praça principal também foi destruída e reconstruída: "Das quatro igrejas que existiram em Arraias, resta apenas uma, a MATRIZ, reconstruída com o aproveitamento dos velhos paredões da primeira” (CORDEIRO, 1989, p. 36).

Aos poucos a cidade vai se vestindo de novidades, preenchendo seus espaços com novas casas em arquitetura moderna, as antigas residências com as janelas voltadas para a rua vão sendo substituídas por novas construções, os muros de pedras vão sendo destruídos pelo tempo e pelas intempéries e a Chapada dos Negros, testemunha silenciosa do nascimento de Arraias vai sendo vagarosamente tomada pelo cerrado, corroída pelo abandono.

Galeffi (2010) salienta que formações urbanas, como Arraias, surgidas a partir do trabalho da mineração organizam-se espontaneamente às margens de rios ou então ao redor de outros acidentes naturais, no caso dessa cidade sua formação acompanhou as sinuosidades do relevo e o remanso das águas dos pequenos rios. E a autora frisa que a praça da igreja ou do mercado se tornam o coração da cidade, lembrando as cidades renascentistas:

[...] da mesma forma que acontecia nas cidades medievais renascentistas: a praça da igreja como local destinado às procissões; a praça da feira para a recepção dos vendedores e dos tropeiros, agentes fundamentais no fornecimento dos mais variados suprimentos, necessários à sobrevivência dos garimpeiros (GALEFFI, 2010)

A praça da matriz em Arraias continua agregando a comunidade em torno de seu centro, todas as festas, comemorações, desfiles cívicos, teatro de rua, carnaval, procissões, missas campais acontecem em seus limites. Nesta praça está concentrada grande parte dos antigos casarões em estilo colonial que resistiram à destruição e em virtude de as festas católicas estabelecerem um ritmo no calendário da cidade, a igreja, coração da praça, possui um relevante papel simbólico dentro deste universo. A praça, a igreja e seu entorno são, portanto, lugares de memória.

Hissa (2008 apud Pidner, 2010, p. 58) afirma: “o espaço não é neutro: isso significa que o espaço é feito de heranças, de escolhas, de testamentos, de valores, de éticas prenhes de cultura". No espaço onde a cidade de Arraias organizou-se, sua cultura desenvolveu-se mesclada pelos sentimentos de manutenção da tradição e de sua destruição, o reflexo dessa dualidade pode ser observado nos aspectos materiais de seu patrimônio arquitetônico que foi perdendo suas características originais, e na herança de antigas tradições preservadas em festas religiosas e/ou populares, como o caso do carnaval com entrudo. Na verdade, as tradições culturais se mantêm graças a diversos fatores, sendo que a possibilidade de diálogo e 
transformação perpassa esta realidade, mas o patrimônio material constituído tanto nas construções como em outras peças antigas como quadros, fotografias, objetos de decoração, utensílios domésticos é um aspecto relevante, pois o simples contato com um destes elementos pode desencadear uma lembrança velada, como observado por Ecléa Bosi (1994, p. 75):

Ao lado da história escrita, das datas, da descrição de períodos, há correntes do passado que só desapareceram na aparência. E que podem reviver numa rua, numa sala, em certas pessoas, como ilhas efêmeras de um estilo, de uma maneira de pensar, sentir, falar, que são resquícios de outras épocas.

Ao mesmo tempo em que Arraias à primeira vista parece ter "parado no tempo", segundo os dizeres de seus moradores, conservando antigas tradições de sua herança cultural, seu centro histórico demonstra o contrário, “[...] o espaço [...] influencia a decisão dos atores sociais e, muitas vezes, condiciona, com precisão, os caminhos a serem percorridos pelas sociedades, pelos grupos, pelas comunidades, pelos sujeitos da vida" (Hissa, 2008 apud Pidner, 2010, p. 58). Portanto, os caminhos percorridos pelos sujeitos da vida da comunidade arraiana ao longo de seus mais de 270 anos de história determinaram suas escolhas, motivando a dicotomia atual: tradição ou modernização?

Nessa simbiose das relações entre o espaço e os sujeitos da vida, ou seja, "os lugares são feitos de homens e de cotidianos sociais, e os homens são feitos de lugares" (Pidner, 2010, p.59), é possível observar que o processo de contradição entre a preservação e a nãopreservação está inerente à própria comunidade. As edificações são como livros contando histórias por meio de suas formas geométricas, suas cores, seus materiais e à medida que elas são destruídas a história de seu povo também se perde.

\footnotetext{
Mas as edificações não são apenas locais de abrigo, tão importantes para o surgimento e desenvolvimento das civilizações. Poderíamos dizer que as edificações são como livros que contam histórias, porém, enquanto nos livros são as palavras que nos trazem significados, nos edifícios são as formas, os materiais, os contextos espaciais, que podem nos dizer muitas coisas acerca de um determinado povo e de um determinado lugar (GALEFFI, 2010).
}

A história contada pelas edificações de Arraias nos remete aos tempos antigos com resquícios da arquitetura colonial, com as paredes erguidas em tijolos de adobe, telhados de barro roliços, janelas de madeira abrindo-se para as ruas: "Os madeiramentos e os telhados ainda são os originais, roliços ou talhados a golpes de ferramentas cortantes, como o machado, e nas paredes também se destacam as numerosas janelas emolduradas ou não e as altas portas em madeira maciça"(Pedreira et al., 2012, p. 102). Neste cenário onde o tempo muitas vezes 
parece ter se esquecido de seguir seu curso natural, a vida da comunidade mistura suas tradições preservadas sob a forma de festejos, culinária, artesanato, mitos e danças com a destruição de seu patrimônio edificado apagando os livros que contam as histórias de seu povo.

\subsection{A CIDADE DE ARRAIAS NO SÉCULO XXI}

A sede municipal de Arraias abriga atualmente aproximadamente 55\% da população estimada em 10.805 habitantes segundo o censo 2014 (Instituto Brasileiro de Geografia e Estatística, 2015). Seu centro composto pela praça matriz onde se localiza a Igreja de Nossa Senhora dos Remédios, padroeira da cidade, é cercada pelos antigos casarões, alguns preservados ou restaurados e muitos completamente destruídos. "Algumas dessas casas ainda conservam algumas fachadas de como foram projetadas. Na arquitetura desses velhos casarões predomina o estilo colonial português e encontram-se ainda as iniciais e o ano que os patriarcas dessas famílias as construíram” (COSTA, 2008, p. 192).

As ruas que compõem o centro da cidade são íngremes, tortuosas, inexistindo qualquer traçado linear, segundo Cordeiro (1989) são características presentes desde as origens da cidade:

\footnotetext{
Quando de sua passagem por Arraias (1739-1740), D. Luiz de Mascarenhas providenciou locais apropriados aos prédios públicos e aconselhou o alinhamento das ruas. Conselho este que não foi atendido, pois elas são hoje, na maioria desalinhadas, compondo-se com a paisagem local e oferecendo ao artista belíssima visão para trabalhos a óleo ou aquarelas (CORDEIRO, 1989, p.33).
}

A cidade, nos últimos anos, cresceu nos setores mais distantes do centro histórico e nestas ruas o traçado mais linear e simétrico acompanha a arquitetura de algumas casas mais modernas, com janelas e portas de vidro blindex expressando o desejo do novo, a ânsia da modernidade. Porém, mesmo nestes setores existe uma mesclagem arquitetônica: casas modernas e bem construídas, limitando-se com pequenos barracos de alvenaria com estrutura deficiente, muitas não possuem muros e as cercas são feitas de arame ou simplesmente inexistem.

Apesar da perda de território sofrida pela cidade nas últimas décadas com a emancipação de Combinado e de Novo Alegre, Arraias ocupa a 24a posição entre os municípios mais populosos do estado, num universo de 139 municípios (Instituto..., 2015). Apesar dessa posição privilegiada a cidade continua vivendo um cotidiano de dificuldades e restrições impostas por 
sua economia frágil, baseada na pecuária extensiva e na agricultura familiar ainda refletindo as mazelas de seu passado onde a renda conservou-se nas mãos das antigas famílias: "com o tempo, estas famílias formaram longas linhagens que perpetuaram os costumes e o poder dos patriarcas, aos quais continuam vinculadas até pelo sobrenome, pelas terras herdadas e pela tradição política ou religiosa" (Costa, 2008, p. 30). Na verdade, as perspectivas econômicas da cidade pouco se alteraram ao longo dos anos, tanto que a maioria de sua população economicamente ativa trabalha no serviço público: municipal, estadual ou federal. O comércio de bens e serviços é restrito e a população depende em vários aspectos da cidade de Campos Belos, no estado de Goiás, incluindo itens essenciais como vestuário, móveis, eletrodomésticos, entre outros.

Segundo a Proposta de Consolidação e Expansão da Universidade Federal do Tocantins do campus de Arraias ( (Fundação..., 2013,p. 8) a região sudeste do Tocantins onde está localizada a cidade de Arraias possui características econômicas semelhantes às outras cidades da região, onde: “[...]a economia é impulsionada pela pecuária (bovinos, suínos, aves, equinos, ovinos e caprinos), agricultura (arroz, feijão, milho, mandioca e soja), coleta de frutos do cerrado, especialmente para produção de sucos, sorvetes e geleias”. As cidades do sudeste tocantinense possuem historicamente baixo desenvolvimento econômico e são caracterizadas por processos de desigualdades sociais, apesar da riqueza cultural e ambiental dessa região

Arraias é entrecortada por pequenos rios, volumosos durante o período das chuvas e em alguns casos quase sem água durante a seca. Os rios Rico e Maravilha juntam-se para formar o Manoel Luís e depois encontram-se com o Cigano formando uma cachoeira que em tempos passados foi balneário da cidade, local onde os moradores banhavam e se refrescavam durante os dias quentes: "e logo abaixo se encontram com o Cigano, após três belas cascatas, que formam a Cachoeira, piscina natural, antes muito frequentada, hoje, meio poluída pelo avanço do progresso" (Cordeiro, 1988, p.15). Na verdade, estes pequenos riachos são compostos por dois rios que em seu percurso pelos diferentes trechos da cidade vão recebendo novos nomes: Dois Irmãos, Rico, Maravilha, Cigano e por fim desaguando no Rio Arraias. Esta estreita relação com as águas surgiu ainda no início do povoado, nas palavras de Rosolinda Cordeiro: "era Arraias que vinha nascendo no aconchego de verde serrania, banhada pelas águas da Biquinha, da qual dizem: quem dela bebe em Arraias fica, por ser leve e boa como é" (Cordeiro, 1989, p. 15).

Atualmente, a cachoeira, chamada por Cordeiro (1989) de piscina natural não pode ser utilizada como balneário da população, devido a ocupação desordenada de suas margens, tornando-se o receptáculo de esgotos e de lixo das casas que a circundam. Apesar de sua 
situação de vulnerabilidade ambiental, ainda recebe algumas mulheres com suas trouxas que vão até o rio para lavagem de suas roupas em períodos de cheia, quando a sujeira e o esgoto descem a correnteza em direção ao Rio Arraias, dando a falsa impressão de que as águas estão limpas novamente.

Como pontuado por Certeau (1994, p. 200): “As histórias sem palavras do andar, do vestir-se, de morar ou do cozinhar trabalham os bairros com ausências; traçam aí memórias que não tem mais lugar - infâncias, tradições genealógicas, eventos sem data", estes pequenos fragmentos instalados no delineamento estético das casas, na fala das pessoas, na forma como contam as suas histórias de vida, constituem o tecido imaginário da cidade e pode ser caracterizado como a mítica do lugar. Em Arraias o tecido que a constitui está entrelaçado nas histórias de seu passado onde o balneário urbano com suas cascatas ainda povoa a imaginação de seu povo.

O lugar antropológico definido por Augé (1994, p. 76): “[...] é o lugar inscrito e simbolizado [...] incluímos na noção de lugar antropológico a possibilidade de percursos que nele se efetuam, dos discursos que nele se pronunciam e da linguagem que o caracteriza". Neste sentido o lugar antropológico constituído nesse espaço está carregado de inúmeras significações, desde o muro de pedras, construção de escravos anônimos, envolvendo a cidade, passando pelas relações pessoais caracterizadas pelo domínio secular das famílias tradicionais, chegando aos movimentos da dança de súcia $^{7}$ em frente à igreja matriz na comemoração da festa da santa padroeira da cidade. Gestos, palavras, símbolos, ritos e mitos fazem de Arraias esta teia de sentidos e significados evocando o que Zaoual (2003, p. 28) chama de sítios simbólicos: “[...] o sítio simbólico de pertencimento é um marcador imaginário de espaço vivido. Em outros termos, trata-se de uma entidade imaterial (ou intangível) que impregna o conjunto do universo local dos atores".

Além da sede municipal, Arraias possui duas comunidades quilombolas: Lagoa da Pedra e Kalunga Mimoso compondo este sítio simbólico de pertencimento como lugares antropológicos.

\footnotetext{
${ }^{7}$ Súcia: dança de origem africana trazida pelos antigos escravos da Coroa portuguesa, em que os instrumentos utilizados são tambores e cuícas e onde os homens e mulheres bailam em movimentos circulares com vários ritmos, compõe a herança cultural da comunidade, inclusive tomando parte da tradição religiosa dos festejos da padroeira na igreja matriz da cidade de Arraias (Costa, 2008).
} 
Figura 4: Localização do município de Arraias no Estado de Tocantins

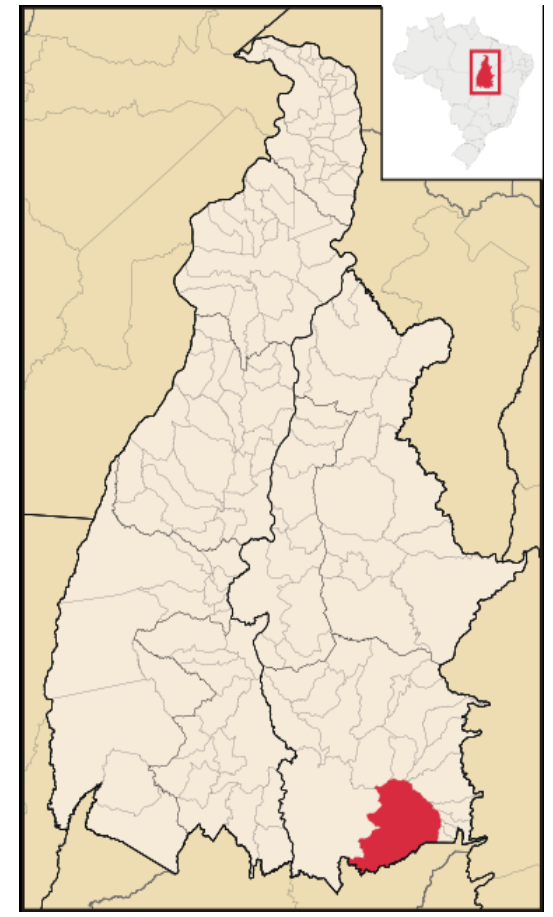

Fonte: site do Wikipédia ${ }^{8}$

\subsection{LAGOA DA PEDRA E KALUNGA MIMOSO: AS COMUNIDADES RURAIS QUILOMBOLAS}

Os quilombos, enquanto territórios culturais, oferecem a possibilidade de diferentes leituras - afetivas, políticas, geográficas e outras (Raquel de Oliveira, 2003).

Segundo Chalub Martins (Centro..., 2013, p. 23) ${ }^{9}$ uma comunidade rural se baseia nas seguintes características: as famílias são organizadas em torno da terra de uso comum, a agricultura é baseada na mão-de-obra familiar e a vivência é solidária. A terra utilizada de forma sustentável reproduz tecnologias de baixo impacto ambiental e os ciclos naturais são preservados, dessa maneira é possível garantir o sustento das famílias, pois a produção nas comunidades rurais não está voltada essencialmente para o comércio. A produção agrícola destina-se ao consumo da comunidade, bem como às práticas sociais de seu cotidiano.

\footnotetext{
${ }^{8}$ Disponível em <http://pt.wikipedia.org/wiki/Ficheiro:Tocantins_Municip_Arraias.svg>. Acesso em 02 out. 2015.

${ }^{9}$ Prof ${ }^{\text {a }}$ Leila Chalub Martins introduziu o conceito de comunidade rural numa apresentação sobre o Projeto "Mulheres das Águas e o desenvolvimento sustentável" realizado na zona rural do município de São João da Aliança (GO) em 2010, numa parceria da Faculdade de Educação e o Centro de Desenvolvimento Sustentável da UnB.
} 
Chalub Martins (Centro..., 2013, p. 28) ${ }^{10}$ afirma que a comunidade rural possui a noção de pertencimento ao território, preservando a memória coletiva do grupo social por meio das tradições, dos mitos e das festas religiosas ou profanas. O núcleo familiar possui importância fundamental dentro deste contexto e suas relações são estendidas envolvendo toda a comunidade nos processos produtivos, onde as regras de uso dos recursos naturais são estabelecidas conjuntamente. No município de Arraias existem algumas comunidades rurais dotadas das características elencadas pela autora, as principais comunidades são as quilombolas. Uma comunidade é considerada remanescente de quilombos por seus moradores possuírem identidade étnico-cultural, com ascendência negra, geralmente localizadas em área rural de difícil acesso (OLIVEIRA, Rosy, 2003, p. 249)

A formação dos quilombos no antigo arraial de Arraias teve início ainda na época áurea do florescimento das minas de ouro, em que a fuga dos escravos insatisfeitos com as condições que lhe eram impostas representava a única forma de resistência e em muitos casos de sobrevivência diante de todas as adversidades daquela época: "na busca de outra alternativa de vida longe do cativeiro, lá iam os escravos negros de Arraias embrenhando-se nas matas tentando ultrapassar as barreiras que os separavam da liberdade" (APOLINÁRIO, 2007, p.131).

Os registros do primeiro quilombo no arraial estão relacionados ao que a historiadora Apolinário (2007) chama de banditismo, onde o processo de aumento populacional estava relacionado ao sequestro, como forma de recrutamento. Nesse ambiente de hostilidade a sociedade escravista vivia em permanente estado de alerta, instituindo medidas repressoras como a criação de tropas especializadas em resgatar os "negros fujões", comandados pela figura do capitão do mato, as tropas eram financiadas pelos próprios moradores do arraial de Arraias e com o incentivo da Coroa Portuguesa.

Apolinário (2007) afirma não existir documentos sobre o destino desses antigos quilombos localizados bem próximos ao arraial, não podendo precisar se foram destruídos e os negros resgatados, ou se conseguiram resistir ao longo dos séculos. A despeito disso, as evidências demonstram que a busca pela liberdade foi mantida e na atualidade o município possui duas comunidades remanescentes de quilombos: Lagoa da Pedra e Kalunga Mimoso do Tocantins ambas reconhecidas institucionalmente pela Fundação Cultural Palmares a primeira em 2004 e a segunda em 2005 (TESKE, 2010; ROCHA-COELHO,2009).

\footnotetext{
${ }^{10}$ Prof $^{\mathrm{a}}$ Leila Chalub Martins introduziu o conceito de comunidade rural numa apresentação sobre o Projeto "Mulheres das Águas e o desenvolvimento sustentável” realizado na zona rural do município de São João da Aliança (GO), em 2010, numa parceria da Faculdade de Educação e o Centro de Desenvolvimento Sustentável da UnB.
} 
A Comunidade Quilombola da Lagoa da Pedra ocupa uma área de 80 alqueires localizada no distrito de Canabrava, situada a $34 \mathrm{~km}$ da sede municipal, com uma população de 157 moradores, formada por 34 famílias (Teske, 2010). A Lagoa da Pedra não possui registros escritos sobre sua origem e sobre a história de seu povo, mas conserva-se a tradição oral, num processo em que os pais contam as antigas histórias para seus filhos e a tradição se mantém. Segundo Teske (2008) existem duas versões para o surgimento da Lagoa da Pedra: (Farias, R., apud Teske, 2008) afirma que a comunidade surgiu no século XIX antecedendo a abolição da escravatura, quando Joaquim Machado, que segundo a pesquisadora Maria Otília da Costa Telles (1977, apud Teske, 2008) seria descendente de escravos, chegou na região e ocupou estas terras devolutas, localizadas numa região de difícil acesso. Teve dois filhos: Paulino Evangelista Machado e Vitorino Francisco Machado e após sua morte a terra foi dividida entre os dois irmãos. Cabendo a Vitorino a parte da terra que corresponde à Lagoa da Pedra. Em outra versão o início da comunidade se deu com a chegada de Paulino Evangelista Machado juntamente com sua esposa no ano de 1854 na região e após constatar a fertilidade do solo convidou seu irmão Vitorino para ocupar a região e doou-lhe as terras que hoje correspondem à Lagoa da Pedra (TESKE, 2008).

Ainda segundo Teske (2010, p 110): “é bem possível, que, devido ao grau de perseguição e isolamento que lhes foi imposto, que os antepassados tivessem silenciado sobre esta parte da história", por isso a origem dos primeiros moradores da Comunidade está envolta numa atmosfera de incertezas marcada pela oralidade dos moradores mais antigos e por alguns registros esparsos em documentos históricos.

A comunidade constituiu-se conservando suas tradições culinárias, musicais, artísticas e somente no século XXI pode ter a posse da terra, outorgada pela Fundação Palmares, reconhecendo-a como remanescente de quilombo. Os pesquisadores do Núcleo Tocantinense de Arqueologia da Fundação Universidade do Tocantins (Unitins/Nuta) apresentam a versão contada pelo Senhor Neres Francisco Machado (descendente dos fundadores da comunidade) sobre o processo de formação da Comunidade Lagoa da Pedra:

Essas terras aqui foram arranjadas quando Arraias ainda era um arraial [...] Lá tinha a exploração de ouro com os escravos. Aí eles fugiam do Senhor e parou aqui um senhor Viturino Machado, daí foi gerando seu benefício. Não sei bem se ele era escravo, mas sei que essa descendência veio de lá, de Arraias, da Chapada dos Negros, da escravatura de Arraias e parou por aqui. E aqui ele foi acertando, foi criando a família Machado e dando início às residências [...] Com o tempo a população foi crescendo e, com isso, foi tendo direito de posse, devido o tempo de moradia no local, até chegarmos a esse ponto aqui. Devido à nossa descendência de escravos, houve o reconhecimento pelo Governo Federal (PEDREIRA et al., 2012, p.86). 
O nome da comunidade é originado de uma lagoa existente em suas terras, de águas sujas e paradas, imprópria para o consumo. Em suas águas não existem peixes servindo apenas como esconderijo de cobras, suas águas desaparecem na época da estiagem e em sua margem existe uma pedra de aproximadamente 20 metros de comprimento por 3 metros de largura, sendo que apesar de seu pequeno porte, a lagoa tornou-se um marco na comunidade, identificando a região dos remanescentes quilombolas (TESKE, 2008).

A comunidade Lagoa da Pedra, sendo uma comunidade rural mantém as características descritas por Chalub Martins ${ }^{11}$ (Centro..., 2013), mantendo sua economia baseada na agricultura de subsistência cultivando arroz, milho, feijão, mandioca, cana de açúcar, hortaliças e árvores frutíferas, seus moradores utilizam o sistema de trabalho de mutirão, em que uma família ajuda a outra nos momentos em que se faz necessário, por exemplo, na época do plantio, da limpeza e da colheita (TESKE, 2008, 2010).

As tradições culturais são mantidas na comunidade, por meio de suas festas religiosas, suas danças, sua culinária típica e de acordo com os próprios moradores, elas são preservadas por causa da religiosidade sempre presente no dia-a-dia de seus habitantes (Farias, R., apud Teske, 2008). Segundo Eliade (1992, p. 64): "participar religiosamente de uma festa implica a saída da duração temporal 'ordinária' e a reintegração no Tempo mítico reatualizado pela própria festa", por isso em uma comunidade rural o calendário religioso possui um significado tanto mítico como cultural, reatualizando suas tradições. Entre as festas religiosas celebradas na comunidade as principais são a Folia de Reis, Roda de São Gonçalo, Rezas da Ladainha, festas juninas e a caretagem ${ }^{12}$ no sábado de aleluia. A Roda de São Gonçalo pesquisada e relatada pelo Prof. Wolgang Teske é uma dança em devoção a São Gonçalo, que remonta o período colonial preservando uma tradição nascida em Portugal, e sempre acontece como pagamento de uma promessa a São Gonçalo envolvendo toda a comunidade (TESKE, 2008).

[...] descobri uma cultura onde o imaginário, a religiosidade, o sincretismo, a mitologia e o folclore formam um conjunto e demonstram a identidade da Comunidade Quilombola Lagoa da Pedra. Mesmo despossuídos de um histórico escrito e impresso, utilizam-se da tradição oral, que mostra toda a sua força, ao passarem de uma geração a outra os valores, histórias e sua cultura e, através desse mecanismo, conseguem se manter unidos nos seus propósitos (TESKE, 2010, p. 261262).

\footnotetext{
${ }^{11}$ Prof $^{a}$ Leila Chalub Martins introduziu o conceito de comunidade rural numa apresentação sobre o Projeto "Mulheres das Águas e o desenvolvimento sustentável" realizado na zona rural do município de São João da Aliança (GO), em 2010, numa parceria da Faculdade de Educação e o Centro de Desenvolvimento Sustentável da UnB.

${ }^{12}$ Caretagem é uma brincadeira que acontece na noite de sexta-feira santa ou na manhã de sábado de aleluia em que cavaleiros mascarados cavalgam pelas ruas buscando prendas para serem confiscadas e colocadas na praça para serem repartidas entre eles (Costa, 2008).
} 
Além da Comunidade Quilombola Lagoa da Pedra o município abriga em sua extensão outra comunidade originada dos antigos quilombos que são os Kalunga Mimoso do Tocantins. O povoado de Mimoso está localizado a $120 \mathrm{~km}$ da sede municipal, na divisa do estado de Tocantins com o estado de Goiás, situado a margem da foz do Rio Bezerra e do Rio Paranã, estendendo um pouco de seu território no município do Paranã (ROCHA-COELHO, 2009).

É composta, por aproximadamente, 250 famílias distribuídas em pequenos núcleos residenciais, localizados às margens do Rio Bezerra e do Rio Paranã na divisa dos estados de Goiás e Tocantins. Seus núcleos residenciais estão dispostos em pequenas localidades (Curral Velho, Esperança, Deus Ajuda, Cana Brava, Mimoso, Forte, Aparecida, Matas, Ponta da Ilha, Belém e Albino) que, em seu conjunto, formam o que se denomina "comunidade Kalunga do Mimoso de Tocantins" (PIRES; OLIVEIRA, ROSY, apud ROCHA-COELHO, 2009, p. 1).

Os Kalunga são um povo quilombola que habita o norte de Goiás e a região sudeste do Tocantins divididos politicamente por meio da criação do Estado do Tocantins aprovado na Constituição Federal de 1988. “A partir deste período, os Kalunga sofreram uma subdivisão em dois grupos. Neste caso, a criação do estado modificou as fronteiras políticas do território e consequentemente a identidade dos indivíduos os quais se dividem" (OLIVEIRA, ROSY, 2007, p. 11).

A história dos Kalunga do Mimoso é marcada por um processo de busca de identidade deflagrado no reconhecimento de remanescentes quilombolas de seus parentes consanguíneos dos Kalunga de Goiás durante a aprovação da Constituição Federal de 1988. Momento em que esta comunidade não se reconhecia como descendente dos antigos escravos da região, adiando esta discussão por quinze anos. Somente em 2005 os Kalunga do Tocantins reviram sua posição e admitiram a descendência quilombola, em parte como reconhecimento dos efeitos positivos dessa posição ocupada pelos Kalunga de Goiás como também pelo recurso de impedir o processo de grilagem de suas terras, cobiçadas por fazendeiros (OLIVEIRA, ROSY, 2007).

A comunidade baseia sua economia na criação de gado de forma extensiva, sem formação de pastos, o rebanho é criado solto no cerrado e no cultivo de pequenas roças para subsistência onde o excedente é trocado entre as famílias ou então levado para a comercialização na cidade.

As famílias desses agrupamentos rurais se sustentam com as lavouras de mandioca, arroz, milho, abóbora e fumo. Este último é produzido por um número menor de famílias situadas às margens dos rios Cana Brava, Bezerra e Paranã, as quais 
costumam também cultivar pequenas roças de andú, um tipo de feijão verde, amendoim e bananas (OLIVEIRA, ROSY 2007, p. 12).

Segundo Rocha-Coelho (2009) os principais artigos comercializados na cidade são o fumo de rolo, o artesanato típico produzido pelos kalungueiros: cachimbo de argila, peneiras e broacas $^{13}$, a farinha, o gado e derivados.

Suas casas são feitas com tijolo de adobe ou então num tipo de armação com barro socado com taboca e cipó. Existe também um espaço próprio para as festas religiosas da comunidade: "neste local está situada a 'feira', construção feita de alvenaria utilizada nos momentos de festas, reuniões e escola para adultos (EJA) durante os sábados" (ROCHACOELHO, 2009, p. 25).

Os Kalunga Mimoso utilizam-se de vários conhecimentos tradicionais em seu cotidiano, desde a cura das doenças por meio de rezas e do uso de plantas medicinais, como também em sua relação com a natureza: "Exemplo disso é o modo como veem o Cerrado como fonte alimentícia, seja plantando ou usufruindo dos frutos nativos, e como fonte terapêutica" (ROCHA-COELHO, 2009, p. 30).

A palavra calunga possui vários significados: "No Candomblé, "morada dos mortos"; na cosmologia do discurso banto, "fundo do mar", "água grande" ou "grande água"; no Nordeste, "a boneca que é mito de origem dos cortejos dos reis negros dos maracatus" (Oliveira, Rosy, 2007, p.127). Kalunga escrito com K foi uma espécie de homenagem da antropóloga Mari Baiocchi aos quilombolas dessa região que compreende as comunidades do norte de Goiás e sudeste do Tocantins "[...] p papel da pesquisadora se mescla com a própria identidade criada por ela, tornando-a parte do processo de reconhecimento dos Kalunga, em uma espécie de mistura de gêneros" (Oliveira, Rosy, 2007, p.126), considerando todos os significados desta palavra unidos na nova grafia.

Nesse universo onde se misturam diferentes elementos: sertanejos, quilombolas, famílias tradicionais, dançadores de súcia, festas religiosas, a paisagem de Arraias descortinase mostrando suas características, suas cores. Segundo Karina Dias (2010) a paisagem é mais do que um conjunto de objetos reais e concretos distribuídos ao longo do território, a paisagem é a memória viva de um passado morto, como descrito por (SANTOS, M., apud DIAS, 2010, p.125):

\footnotetext{
${ }^{13}$ Bolsa de couro para condução de cereais e outros objetos sobre cavalgaduras. Disponível em $<$ http://dic.busca.uol.com.br/result.html?q=broaca\&group=0\&t=10>. Acesso em 30 nov. 2015.
} 
O que temos diante de nós não são apenas fragmentos materiais de um passado - de sucessivos passados- cuja simples recolagem não nos ajuda muito. De fato, a paisagem permite apenas supor um passado. Se queremos interpretar cada etapa da evolução social, cumpre-nos retomar a história que esses fragmentos de diferentes idades representam juntamente com a história tal como a sociedade a escreveu de momento em momento. Assim reconstituímos a história pretérita da paisagem, mas a função da paisagem atual nos será dada por sua confrontação com a sociedade atual.

Na composição dessa paisagem social, histórica, natural o imaginário se estabelece como “[...] pistas para as potencialidades espirituais da vida humana" (CAMPBELL, 1990, p. 6).

\subsection{BRICOLAGEM DO IMAGINÁRIO}

O processo de bricolagem, do francês bricolage significa, para Lévi-Strauss (1976) a ciência primeira, ou seja, o modo de operação da reflexão mitopoética em que inexistem planos concebidos, operando-se com fragmentos: “[...]o pensamento mítico, este bricoleur, elabora estruturas ordenando os acontecimentos, ou antes, os resíduos de acontecimentos [...]" (LéviStrauss, 1976, p. 43). As características do pensamento mítico, não estão inseridas nos acontecimentos e em sua ordenação, mas nos fragmentos desses acontecimentos, como" [...] testemunhas fósseis da história de um indivíduo ou de uma sociedade" (Lévi-Strauss, 1976, p. $43)$.

Para Campbell (1990) os mitos contam histórias da busca da verdade e da significação da vida humana, e para o autor, os mitos possuem basicamente quatro funções: mística, cosmológica, sociológica e pedagógica. A primeira função diz respeito ao espanto diante do mistério num processo de abertura consciente ao sagrado, a segunda função está relacionada à principal ocupação da ciência, por tratar-se da busca de respostas. A função sociológica do mito valida a ordem social, por isso existe a variação de um mesmo mito em diferentes contextos e por fim a função pedagógica que seria: “[...] como viver uma vida humana sob qualquer circunstância. Os mitos podem ensinar-lhe isso" (CAMPBELL, 1990, p. 32).

Eliade (1991) considera que os mitos descrevem situações dramáticas em que o sagrado aparece no mundo e essa aparição o fundamenta. Além disso, "o mito é uma realidade cultural extremamente complexa, que pode ser abordada e interpretada através de perspectivas múltiplas e complementares" (ELIADE, 1991, p. 11).

Para Maria da Conceição de Almeida (2012) estamos num momento da história do conhecimento em que a ciência e o mito começam a comungar uma relação respeitosa onde o mito deve ser considerado como representação significativa, ou seja: 
Essas duas formas de representação do mundo são dotadas de singularidades próprias, cabendo ao mito e às mitologias o papel de repor o estoque estético e poético da compreensão do mundo. Como a arte e a música, o mito pode ser descrito como uma reserva poético-estética da condição humana (ALMEIDA, 2012, p. 142).

O mito em suas diferentes formas e nuances ajuda a contar a história de uma comunidade de maneira poética dando ênfase ao imaginário que permeia sua realidade. No caso de uma cidade antiga, palco de tantas lutas e labutas, onde seu povo viveu experiências históricas de importância regional e nacional, existe guardado um tesouro de valor idêntico aos seus registros históricos: suas lendas, seus mitos, as estórias que o seu povo conta.

Ao adentrar este universo mítico algumas considerações a respeito dos seus moradores dão início à composição dessa trajetória no território dos sonhos, "o conhecimento nasce de nossa amorosa comunhão com o mundo. O real é uma ficção: não se encontra feito (prêt-aporter), nem em nível cognitivo nem em nível social” (VERGANI, 2009, p. 180).

Suárez (1998) afirma que o processo produtivo de Arraias se ajusta às condições ambientais e mudou muito pouco nos últimos cem anos, relacionando-se diretamente com uma historiografia de transcendência mítica, fazendo "[...] do imobilismo e da rusticidade sertanejos um imperativo de sentido ou significado" (Suárez, 1998, p. 35). Esta mítica presente na narrativa de seus moradores descreve as categorias dos habitantes de suas distintas regiões: sertões, caatinga e cidade.

O cerrado em suas características regionais, muitas vezes, é interrompido por porções de floresta subtropical, estas porções de floresta são chamadas pelos habitantes, de caatinga e o cerrado denominado de sertões. As terras dos sertões são porosas e ácidas, representando $70 \%$ do território municipal e permitem o cultivo de pequenas lavouras ao longo dos rios e como são ricas em pastagens naturais sua ocupação é voltada principalmente para a pecuária extensiva. A caatinga representa uma faixa de terra úmida a noroeste do município e teve sua ocupação desencadeada apenas no início do século XX, ao contrário dos sertões onde a ocupação da terra aconteceu desde a época da mineração do ouro, no século XVIII. A "rua" na linguagem popular é o lugar onde encontra-se a sede municipal, com seu pequeno comércio, agências bancárias, agência dos correios, agência do Instituto Nacional da Seguridade Social (INSS), o campus da Universidade Federal do Tocantins (UFT), os setores residenciais, as igrejas, enfim: a cidade e situa-se na região dos sertões (SUÁREZ, 1998).

Myréa Suárez identifica a historiografia mítica dos moradores de Arraias identificando suas características principais, ou seja, "neste discurso, os moradores do sertão não são todos 
sertanejos" (Suárez, 1998, p. 37). Eles são classificados como: catingueiros, sertanejos e arraianos: os primeiros são imigrantes recentes, moram próximos uns dos outros, são esclarecidos, modernos, porém considerados fracos ao contrário dos sertanejos que são comumente chamados de fortes. Os sertanejos e os arraianos são nativos, ambos conservadores, uns moradores dos sertões e os outros, os arraianos, moradores da região central da cidade, donos dos antigos casarões históricos.

Enquanto a categoria arraiana refere-se a um grupo social, definido em termos de poder e posição no processo produtivo, as de "catingueiro" e sertanejo apontam para maneira de falar, agir, compartilhar, comer, beber, legislar, etc., que distinguem povos civilizados e atrasados. Trata-se de uma versão popular do discurso erudito sobre o eterno e imutável sertão (SUÁREZ, 1998, p. 38).

A historiografia mítica dos moradores de Arraias identificada por Suárez (1998) conecta-se a outros mitos estabelecidos neste sítio simbólico de pertencimento remontando ao início deste povoado.

A origem do nome da cidade de Arraias está envolta no processo de estória contada e recontada por seus antigos moradores que beira a constituição de mito, como Vergani (2009, p. 99) indica: “ As construções utópicas do imaginário penetram todo o tecido da vida cultural. Poder-se-á falar de uma genética do homo signifer: o progresso da sua consciência será o progresso da sua prenhez simbólica”. Na época da fundação do arraial de Palma, atualmente município de Paranã, o Ouvidor Teotônio Segurado enviou ao seu adversário político o Capitão Felipe Antônio Cardoso um dos fundadores do arraial de Arraias (naquela época ainda sem denominação) algumas arraias pescadas no Rio Paranã sugerindo com isso o nome do arraial que estava se formando. Imagina-se que este ato foi apenas uma brincadeira entre antigos políticos do Brasil Imperial, mas não se sabe ao certo se foi o motivo da escolha do nome: Arraias (Cordeiro, 1989, p. 13). O certo é que o nome do arraial que muito mais tarde veio a se constituir em cidade, carrega uma lembrança de disputa política e ofensa velada, remetendo ao que Costa (2008) destaca em sua tese: quais os motivos de se nomear um povoado de Arraias? Pela cor parda de seus habitantes? Pelo caráter arredio de seu povo? São indagações que se perderam no tempo e constituíram o imaginário dessa sociedade, remetendo ao pensamento de Castoriadis:

Antes de tudo, é certamente um nome. Mas esse nome, convencional e arbitrário, será assim tão convencional e arbitrário? Esse significante remete a dois significados, que reúne indissoluvelmente. Ele designa a coletividade em questão, mas não a designa 
como simples extensão, ele a designa ao mesmo tempo como compreensão, como alguma coisa, qualidade ou propriedade (CASTORIADIS, 1982, p. 178).

Para os antigos moradores da cidade de Arraias o motivo das dificuldades enfrentadas pelo município para se desenvolver economicamente relaciona-se diretamente ao processo de construção dos muros de pedras circundando a cidade em vários trechos e que foram construídos pelos escravos, a mando de seus senhores, provavelmente como forma de delimitação entre as antigas propriedades rurais. Costa (2008, p. 130) destaca que os mais idosos descrevem a presença dos muros como sinal de infortúnio da seguinte maneira: "O sofrimento dos escravos nas minas e na construção dos muros de pedras que delimitavam as terras dos senhores é que impede que a cidade tenha um maior desenvolvimento na atualidade".

Esta lenda presente na memória dos mais antigos da cidade, permeia o imaginário local justificando o tempo atual marcado por dificuldades e atraso econômico vivido pela cidade, retomando Castoriadis, apud Losada (2006, p. 34): "Há sempre um passado, que é recriado a partir do presente. A relação com esse passado faz parte da instituição da sociedade: os conteúdos dessa tradição são recriados (reinterpretados?) segundo as significações imaginárias do presente".

[...] é o choro, o soluço dos pretos a subirem as serras, com as pedras na cabeça para construírem os muros, que ainda hoje cercam toda a cidade e fluem tão negativamente sobre ela. Por isso não irão muito adiante, afinal ninguém pode ser feliz em cima da desgraça e dor de uma raça negra, que deu seu sangue para os que hoje vivem nela (entrevistado 05/2005, COSTA, 2008, p. 130).

Neste universo a história de Elesbão: o guardião da Chapada dos Negros se insere com o simbolismo do último escravo, testemunha ocular do fim da riqueza proporcionada pela garimpagem do ouro neste lugar. A vida desse ex-escravo foi pontuada de interrogações e incertezas, Costa (2004) afirma que Elesbão veio morar em Arraias ainda pequeno na companhia de sua mãe e durante bastante tempo ajudou o padre em suas atividades religiosas. De origem humilde andando sempre maltrapilho e na companhia de cães passou a acreditar que tinha poderes de se transformar em lobisomem, na Chapada dos Negros repetia o ritual de transformação em noites de lua cheia. Viveu num casebre à beira de um córrego na entrada da Chapada e veio a falecer no município de Campos Belos ainda na década de 1970 sendo enterrado em Arraias. Durante sua vida sobreviveu às custas da extração de ouro na Chapada em pequenas quantidades, o que lhe permitia trocar o ouro por mercadoria em suas visitas à cidade. Em torno de sua figura criou-se a lenda de que sendo a sentinela da Chapada dos Negros 
conhecia a localização de seus últimos filões de ouro, mesmo após a sua morte o negro Elesbão ainda é relembrado como o guardião do ouro da Chapada.

\begin{abstract}
A história é impossível e inconcebível fora da imaginação produtiva ou criadora, do que nós chamamos o imaginário radical tal como se manifesta ao mesmo tempo e indissoluvelmente no fazer histórico, e na constituição, antes de qualquer racionalidade explícita, de um universo de significações (CASTORIADIS, 1982, p. 176).
\end{abstract}

A cidade de Arraias cercada por morros, possui em seus arredores um monte com simbolismo peculiar: é o Morro da Cruz. "[..] Cada sociedade, define e elabora uma imagem do mundo natural, do universo onde vive, tentando cada vez fazer um conjunto significante, no qual certamente devem encontrar lugar os objetos e seres naturais [...]" (Castoriadis, 1982, p. 179). Este morro agrega um sentido especial no feriado da sexta-feira santa, em que a subida de suas encostas íngremes representa o sacrifício e a penitência dos cristãos na preparação para o domingo de Páscoa (Costa, 2004). Para Campbell (1990, p. 97) “ A sacralização da paisagem local é uma função fundamental da mitologia [...] A paisagem, o lugar de morada, se torna um ícone, uma figura sagrada", desse modo este morro agrega em sua paisagem a primeira função mitológica descrita pelo autor, a dimensão mística.

Outro local que goza dessa função de sacralização natural é a caverna da Gruta da Lapa localizada a $16 \mathrm{~km}$ da comunidade Lagoa da Pedra e a $32 \mathrm{~km}$ da cidade de Arraias, "um complexo de quatro grandes salões, medindo aproximadamente 40 metros de comprimento por 20 metros de altura. As formações de estalactites e estalagmites lembram figuras humanas e animais" (Costa, 2004, p. 144), suas características geológicas são destacadas como: “a caverna é bem ornamentada, possuindo grandes espeleotemas como cortinas, grandes colunas, estalactites e estalagmites [...]" (Rocha; Carloto, 2011) e tem sido usada há bastante tempo como local sagrado de peregrinações, onde os eventos principais são a comemoração de São Bom Jesus da Lapa e de Nossa Senhora D’Abadia, nos dias 6 de agosto e 15 de agosto respectivamente. As romarias até a caverna da Gruta da Lapa nestas datas são compostas pelos quilombolas da Lagoa da Pedra, como também por moradores da cidade de Arraias e de outras cidades do Tocantins, de Goiás e de Brasília que muitas vezes voltam a sua comunidade de origem pelo sentimento de identidade com o local (ROCHA; CARLOTO, 2011).

A gruta da Lapa emerge neste universo mítico carregada de representações sagradas, o pagamento das promessas feitas ao Bom Jesus da Lapa pelos quilombolas é feito sob a forma de bonecos de cera de abelha: "as pessoas fazem algum pedido para alcançar alguma graça, e 
quando a alcança, elas fazem os bonecos ou modelo de alguma parte do corpo e trazem para a caverna como forma de agradecimento" (Rocha; Carloto, 2011, p. 272). Existe também o mito de que há um "quarto" na caverna onde todas as lanternas e velas se apagam ao se adentrar o salão, permanecendo apenas a escuridão completa, este local seria a morada de São Bom Jesus, "passamos pelos pátios cheios de luzes, figuras de deuses, mas quando chegamos ao santuário atingimos o coração, o centro do nosso próprio ser, e encontramos Deus na escuridão" (WEBER, 1986, p. 218).

"Não existe um verdadeiro término na análise mítica, nenhuma unidade secreta que se possa atingir no final do trabalho de decomposição. Os temas se desdobram ao infinito' (LéviStrauss, 2004, p.24), dessa forma o que pode se perceber ao adentrar o universo mítico da cidade de Arraias é a certeza de não se encontrar seus limites, em sua ancestralidade as estórias de seu povo recontam o passado numa ótica diferenciada assemelhando-se ao que Lévi-Strauss (2004) denomina de "anaclástica" ou o "estudo dos raios refletidos e refratados". Nesse processo de reflexão e de refração de raios as antigas lendas vão se misturando ao cotidiano das pessoas que em pleno século XXI se surpreendem com suas estórias:

O mundo moderno apresenta-se, superficialmente, como aquele que impeliu, que tende a impelir a racionalização ao seu extremo e que, por isso, permite-se desprezarou olhar com uma curiosidade respeitosa - os estranhos costumes, invenções e representações imaginárias das sociedades precedentes (CASTORIADIS, 1982, p.187)

Diante dos mitos e lendas que povoam o imaginário da cidade de Arraias formando um tapete de sentidos e de interpretações, conjugado com sua história ímpar onde o tempo foi marcado por transformações e desafios, a instalação do campus da universidade federal representa um novo recomeço expresso na definição: "a universidade deve ser um ponto privilegiado de encontro entre saberes" (Santos, B., 1999, p. 198), este encontro de saberes constitui-se como referência da origem da Universidade Federal do Tocantins. 


\title{
2 UNIVERSIDADE: CAMINHO DA TRANSFORMAÇÃO?
}

\author{
Figura 5: UFT/Campus de Arraias
}

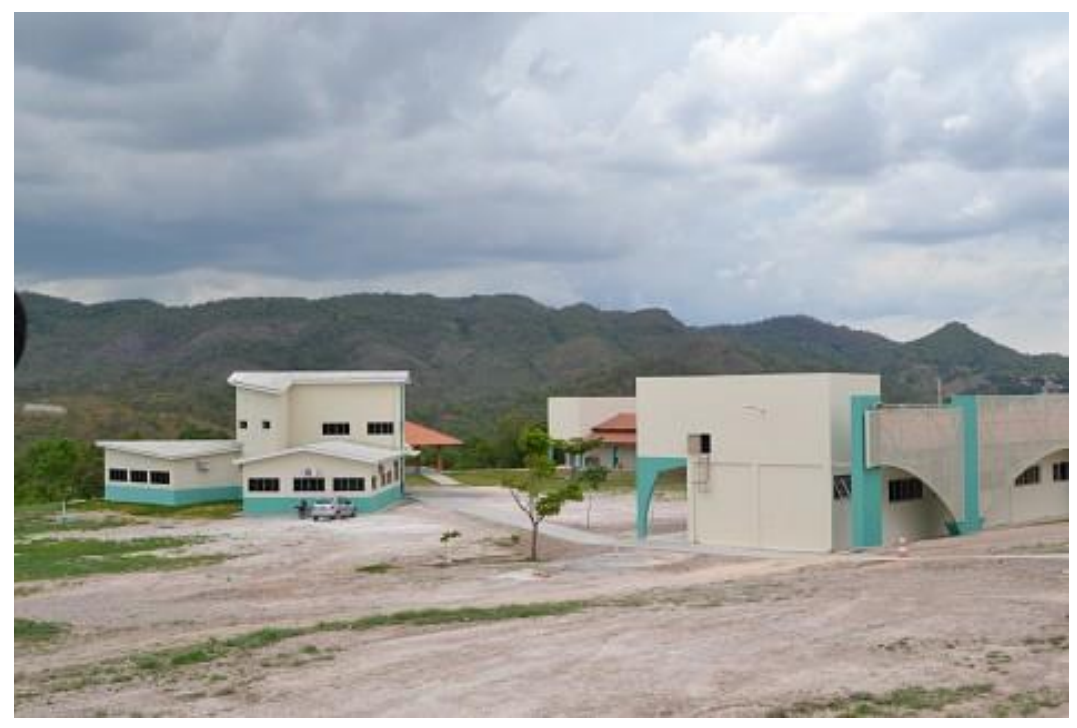

Fonte: Site de busca na internet ${ }^{14}$

\footnotetext{
${ }^{14}$ Disponível em

<https:/www.google.com.br/search?q=uft+campus+de+arraias\&espv=2\&biw=1366\&bih=667\&source=lnms\&t bm=isch\&sa=X\&ved=0ahUKEwjKpYn40s_KAhVFgpAKHTcaCqQQ_AUIBygC\#imgrc=axzne7fr8tvIVM\%3A >. Acesso em 10 dez. 2015.
} 


\subsection{A REFORMA PARADIGMÁTICA DA UNIVERSIDADE}

A Universidade em sua origem representa a possibilidade de transformação de uma sociedade aliando seu caráter inovador próprio da descoberta e da invenção ao acúmulo de conhecimento que a instituição simboliza. Para Morin (2009a) isso decorre da dupla função da universidade: “[...] adaptar-se à modernidade e integrá-la, responder às necessidades fundamentais da formação, proporcionar ensino para nossas profissões técnicas e outras, oferecer um ensino meta profissional e meta técnico (MORIN, 2009a, p.16).

A presença da universidade na cidade de Arraias simboliza o caminho da transformação, desde a sua instalação em 1989, como campus da Universidade do Tocantins (Unitins), instituição estadual, tornando-se campus da Universidade Federal do Tocantins em 2003, sua inserção proporciona a possibilidade de renovação, por meio da busca: ”[...] porque a verdade só é acessível a quem procura sistematicamente, a investigação é o principal objetivo da universidade; porque o âmbito da verdade é muito maior do que o da ciência [...]" (Jaspers, 1965, apud Santos, B., 1999, p.164). Considerando a realidade social e econômica dessa cidade do sudeste tocantinense em que as desigualdades sociais não sofreram grandes modificações ao longo dos anos, a universidade, em sua função e missão permite a busca da transformação, aproximando-se do ideal da universidade utópica proposta por Darcy Ribeiro:

\footnotetext{
Ao contrário, as universidades que se anteciparem, na medida do possível, às transformações sociais poderão converter-se em instrumentos de superação do atraso nacional, em certas circunstâncias, contribuindo decisivamente para a transformação radical de suas sociedades (RIBEIRO, 1978, p. 174).
}

A universidade possui uma dupla missão apontada por Morin (2000): a adaptação da sociedade à Universidade e a adaptação da Universidade à sociedade. Para o pensamento complexo não existe como definir simplesmente uma escolha entre estes dois caminhos, porque a Universidade em sua função transecular, permite a passagem do passado ao futuro, usando como trajetória o presente, ou seja: “ A universidade é conservadora, regeneradora, geradora. Conserva, memoriza, integra, ritualiza um patrimônio cognitivo; regenera-o pelo reexame, atualizando-o, transmitindo-o; gera saber e cultura que entram nessa herança" (Morin, 2000, p. 22). Além disso, a Universidade possui a função transnacional que lhe dá autonomia para realizar sua missão, ultrapassando as barreiras nacionalistas. A conservação do patrimônio cognitivo é fundamental para a sobrevivência da Universidade, mas não pode, de maneira nenhuma representar a formalização de dogmas, impedindo que este mesmo patrimônio passe por processo de regeneração e gere novo conhecimento, novas possibilidades, novos desafios. 
A Universidade, segundo Morin (2000; 2009), vive na atualidade um momento de reforma paradigmática, "trata-se de uma reforma não programática, mas paradigmática, que diz respeito a nossa atitude em relação à organização do conhecimento" (Morin, 2000, p. 26).

Neste sentido, uma reforma paradigmática representa uma mudança de rumo no caminho que a universidade enquanto instituição "conservadora, regeneradora e geradora" do patrimônio cognitivo tem trilhado, pois para Morin (2010, p. 32): “[...] o nível paradigmático é o núcleo forte que comanda todos os pensamentos, todas as ideias, todos os conhecimentos que se produzem sob seu império". O paradigma dominante orienta o pensamento para a disjunção e a redução, onde o conhecimento nasce a partir da separação entre as partes, "queremos conhecer separando, ou desunindo, a ciência, a filosofia, a cultura literária, a cultura científica, as disciplinas, a vida, a matéria, o homem, etc" (2010, p. 33). A reforma do pensamento defendida por Morin $(2000,2009,2010)$ alia as diferentes partes, contextualizando, religando, realinhando ou seja: "a missão primordial do ensino supõe muito mais aprender a religar do que aprender a separar, o que, aliás, vem sendo feito até o presente” (MORIN, 2009, p. 68).

A reforma da Universidade estabelece como fundamento a adoção de práticas transdisciplinares na perspectiva de quebrar as amarras das especializações e permitir o diálogo entre a cultura científica e a cultura das humanidades. "A fim de instaurar e ramificar um modo de pensar que permita a reforma, seria o caso de se instituir, em todas as Universidades e Faculdades, um dízimo epistemológico ou transdisciplinar, que retiraria $10 \%$ da duração dos cursos para um ensino comum [...]” (MORIN, 2003, p. 84).

A transdisciplinaridade é apenas um dos aspectos apontados por Morin (2003) como basilares para promover a reforma da Universidade existindo outros pontos importantes a serem considerados, como a complexidade. A complexidade é o cerne de um desafio posto ao desenvolvimento da ciência “[...] o problema da complexidade não é o da completude, mas o da incompletude do conhecimento" (Morin, 2001, p.176), sendo o conhecimento incompleto temos que aprender a articular suas diferentes identidades para não cairmos nas armadilhas da simplificação e redução aos quais o paradigma da ciência objetiva tem caminhado há tempos.

O pensamento complexo parte da compreensão de que: "[...] o conhecimento das partes depende do conhecimento do todo e que o conhecimento do todo depende do conhecimento das partes” (Morin, 2003, p. 88), assim é possível tecer os conhecimentos distintos numa mesma teia, ao que o próprio termo complexus remete: tecido junto.

A complexidade pode produzir a reforma do pensamento por meio de princípios que Morin (2003; 2009) considera fundamentais como o enfrentamento da incerteza como condição inerente do conhecimento, “a aquisição da incerteza é uma das maiores conquistas da 
consciência, porque a aventura humana, desde seu começo, sempre foi desconhecida" (Morin, 2009, p.99). Igualmente fundamental é a certeza de que o universo não pode ser isolado em partes elementares para ser compreendido pois tudo está interligado, interconectado ou seja: “o conhecimento de toda organização física exige o conhecimento de suas interações com seu ambiente" (Morin, 2001, p.339). Nessa teia do pensamento complexo não existe como separar sujeito e objeto da forma como o paradigma científico atual considera como regra, "a pesquisa é ao mesmo tempo objeto e sujeito, e não se pode evitar o caráter intersubjetivo de todo relacionamento do homem com o homem” (MORIN, apud BIANCHI, 2010, p. 121).

As raízes dessa reforma paradigmática da Universidade permeiam o nascimento da Universidade Federal do Tocantins (UFT) e em certa medida orientam seus passos ao longo do caminho nesses 13 anos de existência.

\subsection{A UNIVERSIDADE FEDERAL DO TOCANTINS E A PROPOSTA DE REFORMA DO PENSAMENTO}

A Universidade Federal do Tocantins (UFT) originou-se da federalização de parte da Universidade do Tocantins (Unitins) com a transferência de cursos de graduação e de pósgraduação, de alunos e de estrutura física para a recém-criada UFT:

[..] a Universidade Federal do Tocantins foi instituída pela Lei 10.032, de 23 de outubro de 2000 e iniciou suas atividades a partir de maio de 2003, com a posse dos primeiros professores efetivos e a transferência dos cursos de graduação regulares da Universidade do Tocantins, mantida pelo governo estadual (FARIAS, M., 2011, p.2).

A UFT herdou da Unitins sua composição multicampi, composta por sete unidades localizadas nos municípios de: Arraias, Araguaína, Gurupi, Miracema, Palmas, Porto Nacional e Tocantinópolis, distando entre 60 a $600 \mathrm{~km}$ de Palmas, capital do estado, onde localiza-se a reitoria. A universidade contava com 29 cursos de graduação e quatro programas de mestrado strictu sensu e na posse dos primeiros professores efetivos em 15 de maio de 2003, realizou-se a primeira assembleia onde foi definida uma comissão de professores para eleger o reitor e vicereitor sendo que em julho de 2004 foi nomeado o Prof. Dr. Alan Barbiero como o primeiro reitor da instituição (UNIVERSIDADE ..., 2007). 
Figura 6: Mapa do Tocantins/Localização dos campi da UFT nas regiões do Estado

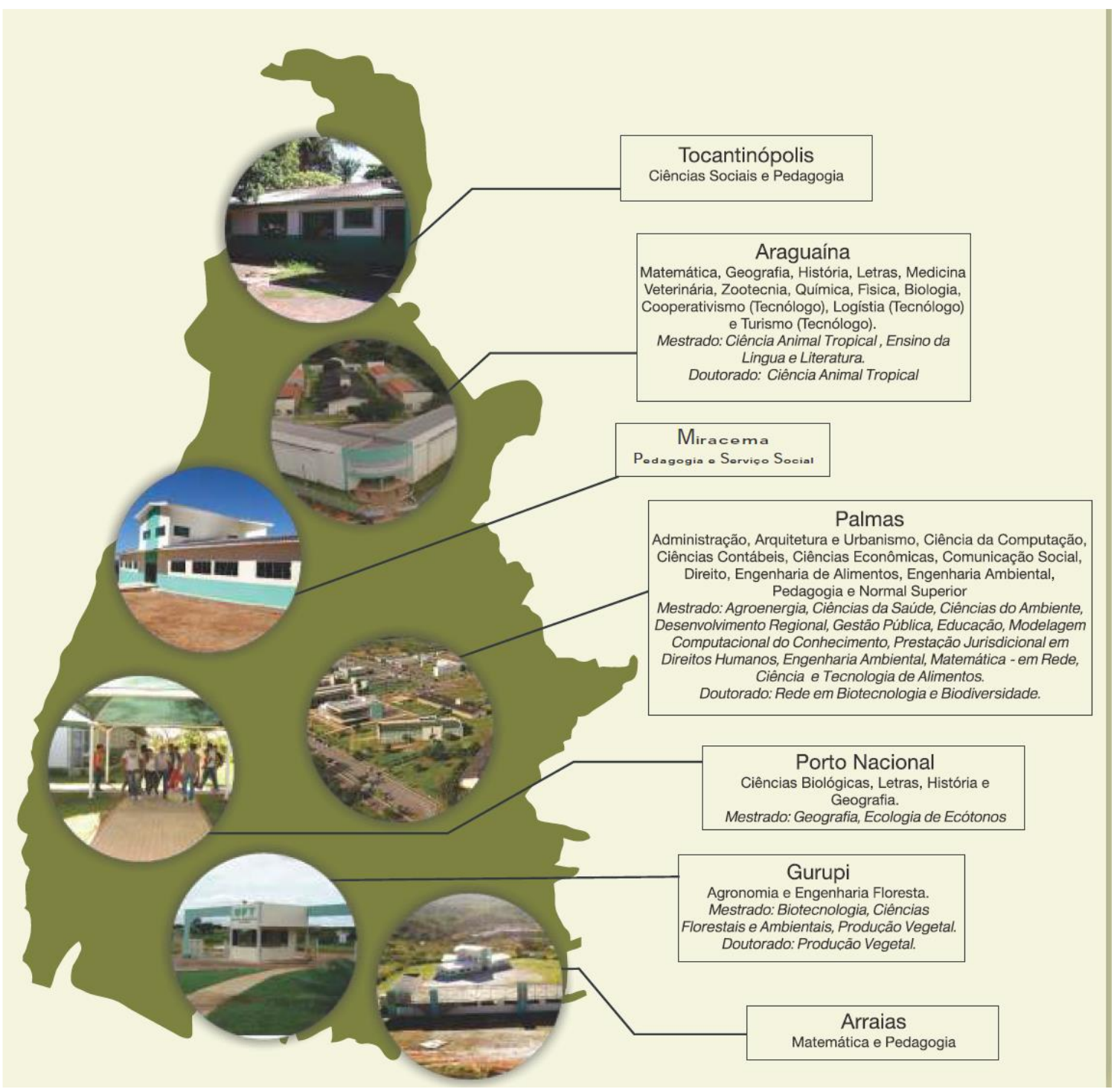

Fonte: UFT em Números 2012

A parceria entre a UFT e o Centro de Desenvolvimento Sustentável (CDS) da Universidade de Brasília (UnB) iniciou-se logo nos primeiros passos da universidade recémcriada: no momento de elaboração do seu planejamento estratégico, desencadeada por meio do estreito laço de amizade entre o então reitor da UFT: Prof. Dr. Alan Barbiero e o então diretor do CDS: Prof. Dr. Elimar Nascimento: “ele me convidou e então com a equipe que me indicou nós organizamos o planejamento estratégico"(informação verbal) ${ }^{15}$. O planejamento estratégico aconteceu como uma elaboração conjunta, onde a reitoria, os coordenadores dos campi e dos cursos, representantes das categorias de técnicos administrativos, docentes e discentes

\footnotetext{
${ }^{15}$ Conhecimento adquirido por meio de entrevista concedida por Elimar Nascimento, professor do Centro de Desenvolvimento Sustentável da UnB em 26 nov. 2013.
} 
participaram de oficinas para discussão e elaboração dos parâmetros norteadores dessa nova universidade (Governo Federal, 2006). A UFT foi despontando neste cenário de efervescência e "fez a opção de ser propositiva, buscar a compreensão e se colocar como participante ativa de um mundo que passa por transformações cada vez mais velozes” (BARBIERO, 2012, p. 7).

"Então foi um período interessante, houve muita discussão em relação a missão da universidade principalmente por causa da questão da Amazônia, muitos campi, principalmente os cursos de ciências agrárias não se sentem inseridos na Amazônia [...]"(informação verbal) ${ }^{16}$ e após todas as discussões o planejamento estratégico da UFT foi aprovado e constituído para o período de 2006 a $2010^{17}$. Para o Prof. Elimar Nascimento a UFT venceu as metas propostas no planejamento antes do tempo ser concluído, por causa do empenho de sua equipe, havia segundo ele um envolvimento de todos neste processo de construção da nova universidade:

\footnotetext{
A equipe muito dedicada, não só o reitor como todo o pessoal. Uma coisa que sempre me chamou a atenção era um pouco a forma como as pessoas, os professores se envolviam, buscavam edital, concorriam edital, ganhavam verba para a pesquisa, para viagem a congresso, havia assim um élan, uma juventude muito salutar, digamos assim, dentro da universidade (INFORMAÇÃO VERBAL) ${ }^{18}$.
}

Foi neste cenário que se originou dois grandes projetos protagonizados pela UFT reafirmando o seu compromisso com a reforma do pensamento: o processo de avaliação internacional organizada pelo Observatório Internacional da Reforma Universitária (ORUS) em parceria com o Centro de Desenvolvimento Sustentável (CDS) da Universidade de Brasília (UnB) sobre três eixos: sustentabilidade, interdisciplinaridade e inserção social e a realização do "Seminário Internacional Crise Civilizacional: Distintos Olhares- Transição de paradigma de desenvolvimento dos países do Sul". Um encontro de dimensão global, o primeiro de tamanho porte realizado em um país latino americano que teve como objetivo discutir e contribuir para a compreensão e enfrentamento da crise global, promovendo o diálogo e a troca de conhecimentos entre diferentes esferas sociais e intelectuais, para ser traçado um novo modelo de civilização baseado na sustentabilidade.

Segundo o Prof. Elimar Nascimento a proposta da UFT protagonizar, como primeira universidade brasileira, a avaliação internacional promovida pela ORUS surgiu numa reunião

\footnotetext{
${ }^{16}$ Conhecimento adquirido por meio de entrevista concedida por Alan Barbiero, primeiro reitor da Universidade Federal do Tocantins, na Secretaria de Meio Ambiente do Tocantins em 29 nov. 2013.

${ }^{17}$ Missão da UFT: é produzir e difundir conhecimentos para formar cidadãos e profissionais qualificados, comprometidos com o desenvolvimento sustentável da Amazônia (Planejamento Estratégico UFT 2006- 2010).

${ }^{18}$ Conhecimento adquirido por meio de entrevista concedida por Elimar Nascimento, professor do Centro de Desenvolvimento Sustentável da UnB em 26 nov. 2013.
} 
do comitê científico da instituição em Paris, e foi sua a indicação da Universidade Federal do Tocantins como pioneira desse processo o que acabou conduzindo à proposta do seminário:

\begin{abstract}
Então a gente fez este trabalho e durante o trabalho surgiu a ideia do seminário internacional, que o Alan achou uma ideia muito boa, no caso a ideia foi do Alfredo Pena-Vega, não foi minha, foi do Alfredo. Imediatamente o Alan casou com a ideia e para nossa surpresa, o Morin, Edgar Morin, (grifo do autor) não só aceitou como veio (INFORMAÇÃO VERBAL) ${ }^{19}$.
\end{abstract}

Estes dois acontecimentos: a avaliação internacional e a realização do seminário internacional marcaram a constituição da UFT como universidade comprometida com "[...] uma revisão paradigmática dos pressupostos epistemológicos clássicos, superando a lacuna entre cultura científica e cultura popular [...]" (Carrizo et al., 2012, 170). Estes dois momentos integram a construção de uma utopia dentro do espaço simbólico da universidade revelando o que Boaventura Sousa Santos observa como preponderante na universidade pós-moderna: "Numa sociedade desencantada, o re-encantamento da universidade pode ser uma das vias para simbolizar o futuro" (SANTOS, B.,1999, p. 200).

\title{
2.3 AS DIMENSÕES DA UNIVERSIDADE FEDERAL DO TOCANTINS EM ANÁLISE
}

A oficina de avaliação internacional organizada pelo Observatório Internacional de Reforma Universitária (ORUS), organização não governamental criada por Edgar Morin e dirigida por Alfredo Pena-Vega em parceria com o Centro de Desenvolvimento Sustentável (CDS) da Universidade de Brasília (UnB) sob a direção do Prof. Elimar Nascimento aconteceu em novembro de 2009 no campus da UFT de Palmas com a apresentação dos resultados da pesquisa que foi realizada na UFT no período de 2008 a 2009 tendo como objetivo avaliar as dimensões da sustentabilidade, interdisciplinaridade e inserção social na prática cotidiana de alguns cursos da instituição.

A pesquisa de avaliação internacional contou com a participação de pesquisadores, mestrandos e doutorandos do CDS e durante a realização da oficina para discussão dos resultados, foram convidados: Alfredo Pena-Vega, sociólogo e pesquisador do Centro Edgar

\footnotetext{
${ }^{19}$ Conhecimento adquirido por meio de entrevista concedida por Elimar Nascimento, professor do Centro de Desenvolvimento Sustentável da UnB em 26 nov. 2013.
} 
Morin da École des Hautes Études em Sciences Sociales (EHESS-CNRS, França), Luis Carrizo, psicólogo e vice-diretor do Centro Latino-americano de Economia Humana (CLAEH, Uruguai) e Luis Flores, filósofo e professor da Universidade Católica do Chile. Na oficina professores, estudantes e gestores da UFT estiveram presentes fazendo uma reflexão sobre os caminhos que a universidade tinha trilhado até aquele momento e quais eram as perspectivas para o futuro.

\footnotetext{
Uma atividade dessa natureza é pouco frequente, especialmente na América Latina, onde as instituições de nível superior resistem em refletir sobre suas próprias práticas, pensar-se a si mesmas, rever suas estruturas e papel social para mudar, se transformar e melhor responder às demandas da sociedade contemporânea (CARRIZO et al., 2012, p. 169)
}

Na dimensão da sustentabilidade foi utilizada a metodologia da pegada ecológica que “ [...] revela a pressão que as atividades humanas exercem sobre o meio ambiente por meio da identificação da demanda da população por recursos naturais e da capacidade que o ecossistema natural tem de supri-la" (Ramos; Cabral, 2012, p. 21). A pesquisa teve como objetivo determinar a pegada ecológica anual no campus da UFT/Palmas no período de agosto de 2008 a agosto de 2009, demonstrando um caráter de pioneirismo pois naquele momento apenas algumas universidades em todo o mundo utilizavam a discussão da sustentabilidade como enfrentamento da crise ambiental (NASCIMENTO; PENA-VEGA, 2012).

A pesquisa sobre a interdisciplinaridade empregou a metodologia do benchmarking que objetivava "identificar as boas práticas interdisciplinares em universidades internacionais, analisar fatores comuns e possibilidades de caminhos a partir delas" (Costa; Nascimento, 2012, p. 39). A partir dessa pesquisa foram escolhidos alguns cursos da UFT, campus de Palmas, para ser feita uma análise baseada em alguns critérios da interdisciplinaridade, considerando-a como “o principal caminho de construção do conhecimento e de fortalecimento da missão social da Universidade perante a sociedade" (LUDEWIGS; AZEVEDO, 2012, p.101).

A inserção social também elaborou suas análises a partir da metodologia do benchmarking identificando em diferentes instituições de ensino no Brasil práticas que caracterizassem experiências exitosas de inserção social universitárias. A inserção social destacada neste trabalho associa-se à ideia de inclusão, pontuando o desenvolvimento de atividades de extensão e ações afirmativas desenvolvidas na Academia (Frate; Vicentim; Chalub Martins, 2012, p.113). No espaço da UFT foi desenvolvida uma análise de três programas de extensão voltados à inserção social usando-se a metodologia de diálogos abertos por meio dos grupos focais e entrevistas semiestruturadas com atores dos programas. 
Ao final a oficina da apresentação e discussão dos resultados da avaliação internacional realizada na UFT nas dimensões da sustentabilidade, interdisciplinaridade e inserção social numa parceria entre a ORUS e o CDS sugeriram caminhos possíveis para que a Universidade recém-criada pudesse alcançar o nível de excelência nestes aspectos decorrente de sua situação geográfica privilegiada, onde convergem distintos ecossistemas e diferentes culturas: "É um ecótono, um encontro, uma conversa de biomas diferentes, de cultura diferente, quer dizer tem uma presença indígena ainda muito forte, presença também de quilombola, então é uma diversidade cultural muito interessante"(INFORMAÇÃO VERBAL) ${ }^{20}$.

\subsection{SEMINÁRIO INTERNACIONAL: ENCONTRO DOS DISTINTOS OLHARES}

O "Seminário Internacional Crise Civilizacional: Distintos Olhares- Transição de paradigma nos países do Sul” aconteceu entre os dias 22 à 24 de junho de 2009 no auditório Cuica do campus da UFT em Palmas, numa parceria entre o Instituto Internacional de Pesquisa sobre Política Civilizacional (IIRPC), Centro de Desenvolvimento Sustentável (CDS), Universidade de Brasília (UnB), Fundação Universidade do Tocantins (Unitins) e Universidade Federal do Tocantins (UFT), reunindo pesquisadores de várias áreas e de diversos países como também lideranças políticas para debaterem a crise do modelo de civilização e a transição de paradigma. Os temas debatidos versaram sobre aquecimento global, crise energética, conservação ambiental, equidade e governança mundial. A presença do pensador contemporâneo Edgar Morin, considerado um dos maiores intelectuais da atualidade, inclusive como um dos idealizadores do evento, tornou o encontro relevante tanto do ponto de vista científico, como também na dimensão da cultura humana.

O objetivo principal desta experiência foi o de contribuir para a compreensão e enfrentamento da complexidade das causas da crise global que vivemos, utilizando a transversalidade entre distintos saberes e olhares, de forma a permitir que surja uma rede entre os países para viabilizar o diálogo, assim como ações conjuntas em prol de um novo mundo (PENA-VEGA, 2015, p. 16)

O seminário foi um marco tanto para a região Norte onde se localiza o estado de Tocantins: “o mais novo estado da Federação Brasileira recebeu em 2009 um dos mais

\footnotetext{
${ }^{20}$ Conhecimento adquirido por meio de entrevista concedida por Elimar Nascimento, professor do Centro de Desenvolvimento Sustentável da UnB em 26 nov. 2013.
} 
importantes eventos científicos internacionais" (Souza, 2015, p.25), como para a UFT que sediou o evento e teve a oportunidade de participar das discussões acerca da crise civilizacional e dos caminhos que conduzem à mudança de paradigma. Além de que a realização do seminário promoveu inúmeras relações interpessoais que se estabeleceram num clima de cordialidade incomum em eventos dessa natureza.

Figura 7: Abertura oficial do Seminário Internacional Distintos Olhares na UFT/ Palmas, Tocantins 2009

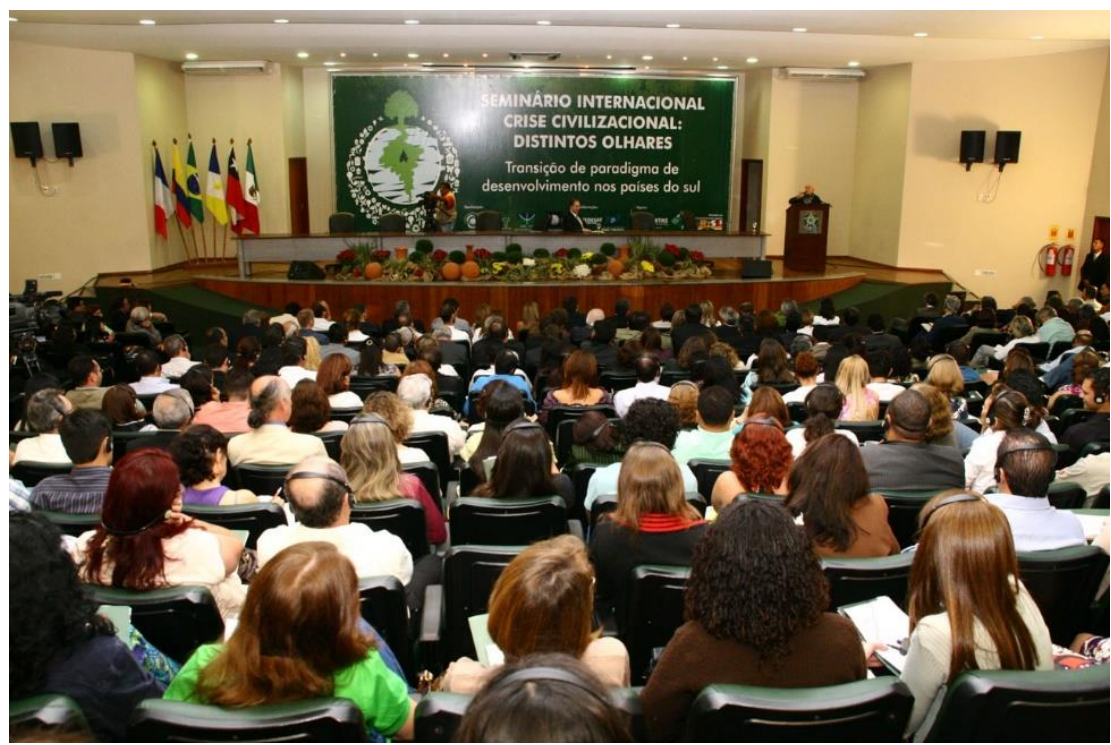

Fonte: Página da Universidade Federal do Tocantins ${ }^{21}$

O momento mais significativo e simbólico do seminário foi a outorga do título Doutor Honoris Causa a dois expoentes de distintos saberes: Edgar Morin, sociólogo e pensador francês, internacionalmente conhecido como representante do saber científico e Dona Raimunda, representante do saber popular, quebradeira de coco babaçu, liderança de movimento comunitário: “[...] são ícones que comprovam a vocação agregadora da UFT, que reconhece a necessidade de diálogo entre o conhecimento popular e o conhecimento científico no processo da construção de saberes [...]" (Silveira, 2015, p.19), concretizando a quebra do paradigma tradicional por meio de uma ação impregnada de simbolismo:

O símbolo faz vibrar simultaneamente todas as nossas capacidades, é um apelo que dinamiza o ser total do homem e provoca uma resposta globalizante. Envolve pensamento e sentimento, intuição e significação -funções que se atualizam sem se inter-excluir (VERGANI, 2009, p.104).

\footnotetext{
${ }^{21}$ Disponível em <http://www.uft.edu.br>. Acesso em 30 set. 2009.
} 
Figura 8 Outorga de título Doutor Honoris Causa ao pensador Edgar Morin e à quebradeira de coco babaçu Dona Raimunda

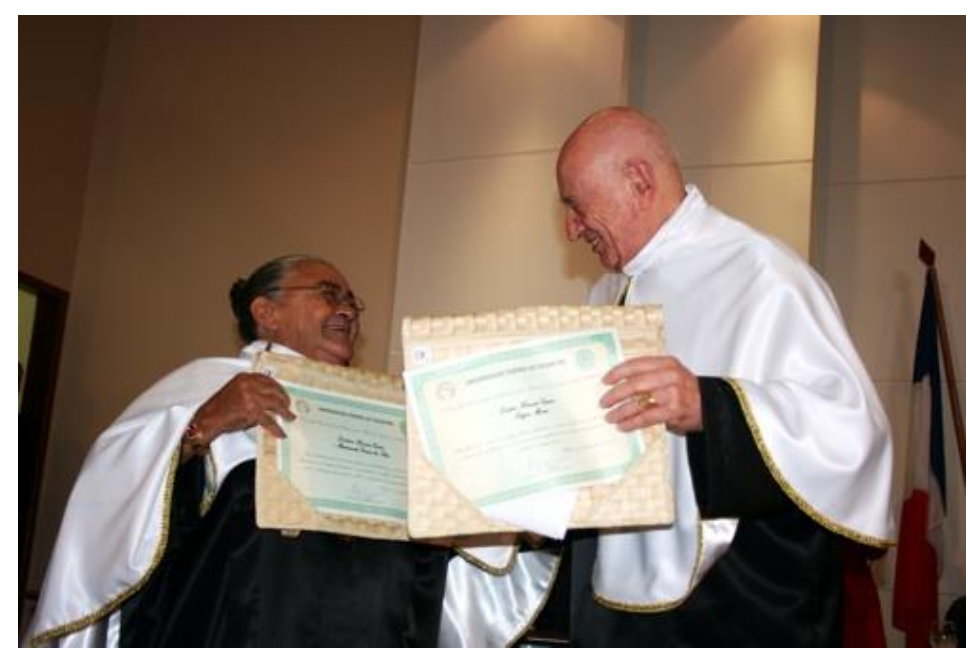

Fonte: Página da Universidade Federal do Tocantins ${ }^{22}$

No último dia do seminário foi elaborado um documento intitulado "Manifesto Tocantins" (Ward, 2015, p. 140 -141), assinado conjuntamente por todos os participantes onde se delineou a busca a qual todos empreenderam durante os três dias do encontro. Segundo as palavras do manifesto várias questões foram propostas, mas a principal delas era se é possível construir outro mundo partindo de todas as potencialidades do mundo atual, utilizando a metáfora da borboleta citada por Edgar Morin em sua palestra de abertura: "Como o verme que se transforma em borboleta. Ele se encasula e se desintegra então para mudar seus processos tanto em forma quanto internos, como o da digestão. Ele se autodestrói e se recria" (Morin, 2009b). Para o pensador contemporâneo o conhecimento científico não pode perder o contato com o conhecimento tradicional das culturas populares: "Não se pode esquecer as culturas regionais. A singularidade de uma cultura faz parte da unidade humana" (2009b). Neste processo de metamorfose o manifesto aponta a necessidade de diálogo criativo entre diferentes esferas do saber para promover a ressignificação do mundo.

O seminário internacional foi um momento ímpar para a Universidade Federal do Tocantins (UFT) e para os seus participantes, durante aqueles 3 dias no mês de junho de 2009, abriu-se a perspectiva de enxergarmos a crise civilizacional com um novo olhar, partindo da visão complexa proposta por Morin (2015, p. 86):

${ }^{22}$ Disponível em <http://www.uft.edu.br>. Acesso em 30 set. 2009. 
[...] porque a característica de uma crise, com enorme perigo de regressão e destruição, também tem chance de imaginação criativa, de diagnóstico relevante, de concepção de uma saída. Por que existiria um despertar criativo? Porque em todas as sociedades, como em todos os seres humanos, existem habilidades criativas adormecidas.

Naquele momento, como professora da UFT enxerguei possibilidades de desenvolver pesquisas que pudessem fortalecer o elo entre o saber tradicional e o saber científico, quebrando paradigmas, como o que foi quebrado naquele gesto concreto durante o seminário, considerando ainda que a UFT por várias razões estava se colocando como solo fértil para que habilidades criativas fossem despertadas, mas eram apenas vislumbres.

A UFT cometeu apenas o erro da ausência de registro escrito na realização do Seminário Internacional Distintos Olhares, em 2009. Um seminário relevante tanto no contexto regional, como a nível nacional, com palestrantes como Edgar Morin, Cristóvam Buarque, Marina Silva, Michel Brunet, Dale Jamieson entre outros pesquisadores nacionais e internacionais, não contou com nenhuma publicação oficial registrando as contribuições deste acontecimento de suma importância para a discussão da mudança de paradigma, tendo em vista, inclusive, que ao final do evento, todos os participantes puderam registrar seu depoimento sobre o evento em folha distribuída pela comissão organizadora com o propósito de posterior publicação (anexo B). Os motivos que contribuíram para esta ausência de uma publicação oficial ultrapassam os objetivos deste trabalho.

Esta lacuna foi de certa forma preenchida pelo fotolivro do jornalista Rodolfo Ward (Ward, 2015) que realizou um resgate fotográfico, com depoimentos de alguns expoentes que participaram do evento e puderam registrar suas impressões nesta publicação, porém é o único registro desta natureza.

\subsection{A INSERÇÃO SOCIAL ${ }^{23}$ NO COTIDIANO DA UFT}

Das três dimensões que foram objeto de análise da avaliação internacional na UFT escolhi a inserção social para ser discutida neste trabalho em virtude de sua aproximação com os objetivos inerentes tanto à Ecologia de Saberes, como à Etnomatemática ambos referenciais teóricos que permeiam a minha reflexão. Estes referenciais serão abordados no capítulo 3, mas em princípio saliento que existem pontos convergentes na Ecologia de Saberes e na

\footnotetext{
23 “"...] associa-se à ideia de inclusão, encaixe, algo que se implanta em outro e, historicamente, tem norteado algumas atividades-fim do ensino superior no Brasil. Tal discussão se relaciona à ideia de que a Academia não pode centrar seus esforços apenas em aperfeiçoar a ciência, mas sim em melhorar as condições de vida do país e transformar sua sociedade" (Frate; Vicentim; Chalub Martins, 2012, p.113).
} 
Etnomatemática que são da ordem da justiça cognitiva promovendo a convivência e o intercâmbio entre diferentes saberes reorientando a relação universidade-sociedade, portanto a dimensão da inserção social possui aspecto relevante nessa discussão.

A Universidade Federal do Tocantins desenvolveu em seu cotidiano alguns aspectos relevantes no sentido da inserção social como prática social, confirmando a análise feita pelos pesquisadores envolvidos com a Oficina de Avaliação Internacional da ORUS “[...] por sua situação geográfica peculiar, pode contribuir para o desenvolvimento de um espaço regional de experiência em pesquisa e inovação interdisciplinar, transformar os sistemas de ensino integrando a educação e a formação de saberes locais[...]" (Carrizo et al., 2012, p.175); uma conquista importante nesse sentido foi a implantação do Sistema de Cotas Indígenas como forma de acesso aos seus cursos de graduação.

Segundo (Silva, F., 2005 apud Carvalho, 2010) a Unitins já contava com estudantes indígenas ingressantes por meio da reserva de vagas, mas não era uma política institucional discutida de forma que garantisse a permanência do indígena na universidade. A UFT em seu primeiro ano de atividade acadêmica (2003) recebeu a demanda levantada pelos indígenas da região expressa na Carta dos Povos Indígenas (2003) com as reivindicações surgidas durante um curso de formação de professores na cidade de Tocantinópolis, onde participaram professores indígenas, lideranças, acadêmicos indígenas e não-indígenas e professores integrantes do Núcleo de Assuntos e Estudos Indígenas da UFT (NEAI). A Carta "assinada pelas etnias Karajá, Javaé, Xambioá, Apinajé, Krahô e Xerente” (Pereira, 2011, p. 61) aborda as necessidades e as expectativas dos indígenas em relação ao seu acesso e permanência na Universidade (CARVALHO, 2010).

Segundo Carvalho (2010) no momento da entrega da Carta à gestão da UFT, em fevereiro de 2004, foi instituída a Comissão Especial de Política de Promoção de Igualdade Racial (CEPPIR) com o objetivo de acompanhar as reivindicações do movimento negro e indígena e elaborar propostas que pudessem ser adotadas pela instituição, consideradas como basilares em sua política de ação afirmativa.

Como resultado dessas discussões no âmbito da Universidade, "[...] a universidade, ao aumentar sua capacidade de resposta, não pode perder sua capacidade de questionamento" (Santos, B., 1999, p. 195), em setembro de 2004 aprovou-se o sistema de cotas indígenas na UFT:

Após várias discussões entre a CEPPIR e outras instâncias da UFT, foi criado em 03 de setembro de 2004, pela Resolução n 3 A/2004, a política de cotas para estudantes indígenas, passando a ofertar, no vestibular de $2005,5 \%$ das vagas em todos os cursos 
e em todos os sete campi, a candidatos indígenas que comprovassem sua etnia por meio de declaração emitida pela FUNAI. (CARVALHO, 2010, p. 105).

A aprovação do sistema de cotas indígenas foi um momento relevante para a Universidade, porém não resultou em suficiente para garantir o ingresso do indígena na Educação Superior: “[...] o Programa Política de Cotas da UFT, quando idealizado, desconsiderou em parte a diferença cultural entre indígenas e não indígenas" (Pereira, 2011, p. 70), esta afirmação se justifica ao se observar o quantitativo de vagas ociosas constante na reserva de cotas, ou seja, grande parte das vagas reservadas aos indígenas são sequer preenchidas.

"O acesso hoje é visto como uma conquista, mas o desafio decorre das estratégias de permanência que a universidade tende a desenvolver para que o aluno indígena permaneça na instituição" (Pereira, 2011, p. 71). A etnia indígena conta com programas institucionais que objetivam garantir a sua permanência, alguns deles são: Programa de Monitoria Indígena (PIMI) e o Programa Bolsa Permanência. O PIMI tem como proposta intensificar a cooperação entre professores e estudantes indígenas nas atividades acadêmicas, onde o monitor, orientado por um professor, acompanha o estudante indígena em questões relativas à Língua Portuguesa e também a outras áreas do conhecimento e o aluno monitor recebe uma bolsa de estudos para a realização do acompanhamento. O Programa Bolsa Permanência é financiado com verba do Programa Nacional de Assistência Estudantil (PNAES) estando vinculado à Pró-Reitoria de Assuntos Estudantis (PROEST), seu objetivo é atender alunos regularmente matriculados nos cursos de graduação da universidade que estejam em situação de vulnerabilidade socioeconômica por meio de uma bolsa de estudos em que o aluno opta por atuar em projetos de extensão, pesquisa ou ensino desenvolvidos por um professor (Bolsa Permanência Acadêmica) ou então atuar em setores de atendimento na esfera institucional (Bolsa Permanência Institucional) (PEREIRA, 2011).

"Outro dado da universidade é que todos os alunos indígenas matriculados na UFT, que não têm uma outra atividade remunerada, recebem auxílio financeiro - bolsa permanência" (Pereira, 2011, p. 73), indicando a importância desse tipo de programa na garantia da permanência dos indígenas nos cursos de graduação da universidade.

O sistema de cotas quilombola foi implantando na UFT por meio da Resolução $\mathrm{n}^{\circ}$ 14/2013 do Conselho Universitário (Consuni) considerando as características do Estado de Tocantins, em que $72,25 \%$ de sua população são predominantemente pardos ou negros e que existiam naquele momento 29 comunidades quilombolas reconhecidas pela Fundação Cultural Palmares e 20 comunidades aguardando a certificação (Universidade..., 2013). Segundo a 
Resolução a partir do $2^{\circ}$ semestre de $2014,5 \%$ das vagas de todos os cursos de graduação da universidade serão destinados aos estudantes quilombolas, considerados como remanescentes: “os grupos étnico-raciais, segundo critérios de auto atribuição, com trajetória histórica própria, dotados de relações territoriais específicas, com presunção de ancestralidade negra relacionada com a resistência à opressão histórica sofrida" (UNIVERSIDADE..., 2013, p. 2).

Os sistemas de cotas indígenas e quilombolas implantados na instituição e os programas de permanência e acompanhamento institucionalizados não esgotam a discussão sobre várias questões que envolvem a democratização do acesso à Educação Superior não somente para os povos indígenas ou para as comunidade quilombolas, mas também para outros estudantes marginalizados por diversas formas: “a universidade será democrática se souber usar o seu saber hegemônico para recuperar e possibilitar o desenvolvimento autônomo de saberes nãohegemônicos, gerados nas práticas das classes sociais oprimidas e dos grupos ou estratos socialmente discriminados” (Santos, B., 1999, p. 198), neste sentido o acesso à universidade não se mostra suficiente para garantir a justiça cognitiva dos saberes desses grupos excluídos da academia por muito tempo. De que forma o conhecimento e a sabedoria destes grupos ‘socialmente discriminados' constituída ao longo de séculos poderão ser considerados no desenvolvimento científico de suas habilidades profissionais? "Como fazer interiorizar numa instituição que é, ela própria, 'uma sociedade de classes' os ideais de democracia e igualdade’? (SANTOS, B., 1999, p.184).

Ainda não existem respostas a todas estas indagações, porém Boaventura Sousa Santos (1999, 2006, 2008) aponta algumas pistas a serem seguidas e todas elas caminham na direção da abertura ao outro, ou seja, somente por meio da escuta sensível de todos os grupos a universidade poderá viver plenamente a democracia do acesso: “A 'abertura ao outro' é o sentido profundo da democratização da universidade, uma democratização que vai muito além da democratização do acesso à universidade e da permanência nesta" (SANTOS, B., 1999, p.195).

\subsection{CAMPUS DE ARRAIAS: O OLHAR EM PERSPECTIVA}

Não é casual que perspectiva abrigue dois sentidos, indicando o ver para a frente e o ver em profundidade, visão conquistada pelo artista, graças à geometria, fazendo da perspectiva ciência geométrica da visão - dióptrica - e ciência da representação dos objetos - óptica (Marilena Chauí, 1988) 
“A Unitins foi formalmente implantada em março de 1991 com os cursos de formação de professores para os campi de Tocantinópolis, Arraias e Guaraí” (Farias, M., 2013, p. 56), a chegada da universidade na cidade de Arraias representou uma conquista levando em consideração suas dimensões populacionais e econômicas que desencadearam um confronto entre o prestígio político de lideranças locais e estaduais (Costa, 2008) e mesmo diante dessa disputa, o campus foi implantado e as atividades de ensino, pesquisa e extensão tiveram início, sendo que em 1994 foi aprovada a implantação do curso de Licenciatura em Matemática e posteriormente, em 2001, o curso Normal Superior com habilitação nas séries iniciais do Ensino Fundamental.

A história da UFT encontra-se imbricada na história da Unitins, no sentido destacado pelo pensamento complexo: "é o conjunto de totalidades/partes que compõem a realidade e constitui o mundo dinâmico onde todos os objetos se interconectam mediante interações recorrentes" (Moraes, 2004, p. 63), dessa forma a Unitins derivou a UFT por meio de seu legado, composto por seus campi, seus alunos, inclusive pela luta que estes enfrentaram na defesa de uma universidade pública e gratuita de qualidade, sendo que no ano de 2003 parte desse legado foi instituído como pertencente a UFT (FARIAS, M., 2013).

O campus de Arraias após a posse dos primeiros professores efetivos da UFT (2003) iniciou a discussão sobre seus Projetos Pedagógicos de Curso (PPCs) e em 2004 reformulou os cursos Normal Superior e Pedagogia, possibilitando a migração dos alunos do curso Normal Superior para o curso de Pedagogia (Farias, M., 2013). O curso de Pedagogia com habilitação em Administração Educacional teve seu PPC reformulado em 2007, após um período de discussões envolvendo os outros cursos de Pedagogia ofertados na Instituição, campus de Tocantinópolis, Miracema e Palmas. A reformulação do PPC do curso de Licenciatura em Matemática aconteceu em 2010 e atualmente tanto o curso de Matemática, como de Pedagogia passam por processo de discussão e reformulação de seus projetos pedagógicos.

$\mathrm{O}$ primeiro curso oferecido na modalidade à distância da UFT foi o curso de Licenciatura em Biologia, aprovado no Conselho Universitário (Consuni) em outubro de 2005 sob caráter experimental, num convênio CESPE/UnB/UFT com a abertura de turmas nos campi de Arraias, Araguaína e Gurupi (FUNDAÇÃO ..., 2010). Atualmente o Campus possui um polo de Educação a Distância em parceria com a Universidade Aberta do Brasil (UAB) e todos os cursos nesta modalidade de ensino estão vinculadas à UAB, inclusive o curso de Biologia. São ofertados os seguintes cursos de graduação: Biologia, Licenciatura em Matemática e Bacharelado em Administração Pública. 
Durante um longo período (2003-2013) os únicos cursos de graduação na modalidade presencial ofertados no campus de Arraias foram Pedagogia e Matemática e o único curso de graduação à distância a Biologia. Em 2012 foi aprovado o curso de Licenciatura em Educação do Campo por meio de edital de chamada pública na modalidade de alternância: tempo universidade e tempo comunidade, com ingresso de 120 alunos por ano, nos primeiros três anos (Farias, M., 2013) sendo que a primeira turma ingressou em abril de 2014.

Como resposta as demandas surgidas na UFT em relação ao fortalecimento dos campi menores como Arraias, Miracema e Tocantinópolis onde existiam apenas dois cursos de graduação na modalidade presencial, foi elaborado um Projeto de Consolidação e Expansão do Campus de Arraias (Fundação..., 2013, p. 11) com vistas a: "ampliar e diversificar as atividades de ensino em níveis de graduação, de pós-graduação, de extensão e de educação básica com a oferta de novos cursos e diferentes modalidades de ensino, conforme áreas de atuação já definida para o Câmpus de Arraias". Por meio desse projeto foram aprovados os cursos de Tecnologia em Turismo Patrimonial e Socioambiental (ingresso da primeira turma no segundo semestre de 2015), Tecnologia em Mineração e Bacharelado em Agroecologia (ambos aguardando aprovação no Conselho de Ensino, Pesquisa e Extensão - Consepe).

O campus de Arraias da UFT, nestes 12 anos de existência, passou por diversos momentos de incerteza resultantes de vários fatores, entre eles da dificuldade em manter seu quadro permanente de docentes e técnico administrativos, tendo em vista as características da cidade e região. A cidade de Arraias praticamente não possui comércio de bens e serviços, não oferece oportunidade de trabalho para os cônjuges dos servidores da Universidade, não possui escolas particulares como alternativa para a educação dos filhos (as). Neste cenário o campus enfrentou propostas de mudança de sua estrutura de ensino para campi maiores e, portanto, com maior capacidade de atender as demandas desse público, mas com o passar dos anos esta possibilidade de escape foi abandonada e a estrutura física do campus foi totalmente remodelada, porém a rotatividade dos servidores continua. Segundo Marizeth Farias (2013, p.116):

De acordo com pesquisa realizada pela Comissão Setorial de Avaliação - CSA do campus, essa rotatividade ocorre em virtude de os docentes e técnicos-administrativos alegarem a falta de estrutura da Universidade e da cidade para atender suas famílias, como a deficiência de área de lazer, trabalho remunerado, cursos de aperfeiçoamento, dentre outros. 
Interessante observarmos que para Chauí (2001, p.35): “ora, a universidade é uma instituição social. Isso significa que ela realiza e exprime de modo determinado a sociedade de que é e faz parte", portanto a situação vivida no Campus de Arraias não está apartada de sua realidade local. Ao contrário disso, ao mesmo tempo em que a sociedade reconhece a importância de abrigar um campus de universidade federal em seu território, as ações cotidianas da comunidade ainda demonstram falta de identificação com o significado da universidade, enquanto agente social de transformação, mantendo hábitos e práticas dos tempos coloniais, muitas vezes mascarados sob diferentes roupagens.

No entanto, segundo Buarque (1994, p.57): “a atual transformação social exige novas reformas que permitam sintonizar seus objetivos, sua estrutura, currículos e compromissos com o futuro. Mais uma vez estão dentro da universidade grande parte das amarras que impedem estas mudanças", a UFT, caracterizada pelo Campus de Arraias ainda não conseguiu desamarrar os nós que a mantém atada ao antigo modelo de universidade, reprodutora de conhecimento, ainda carece do gosto pela aventura de criar o novo, inerente ao próprio conceito de universidade.

Enquanto este intercâmbio não acontece, as pessoas da cidade não se enxergam na Universidade e por sua vez, a comunidade acadêmica composta em sua maioria por docentes e técnicos administrativos oriundos de outros Estados não se sentem acolhidos, ao contrário são considerados estranhos: “embora o 'estranho' seja uma condição colonial e pós-colonial paradigmática, tem uma ressonância que pode ser ouvida distintamente - ainda que de forma errática - em ficções que negociam os poderes da diferença cultural [...]” (Bhabha, 2007, p.30). Esse estranhamento entre a Universidade e a comunidade produz uma atitude de distanciamento entre ambas estabelecendo uma fronteira imaginária que pode ser rompida por meio de um tecido junto, ou seja: “a estrutura cultural do planeta constitui-se de um 'imenso tapete de sítios' que, mesmo sendo singulares, estão imbricados uns nos outros. O que dá à humanidade um aspecto extremamente emaranhado" (Zaoual, 2003, p.104).

No sentido descrito por Zaoual (2003, p. 104) a descoberta dos sítios simbólicos: “[...] entidades imateriais, abertas e fechadas, dinâmicas e surpreendentes", no caso específico da cidade de Arraias: "[...] são como que indicadores do tempo que passa e que sobrevive. Perduram como as palavras que os expressam e ainda os expressarão" (Augé, 1994, p. 72), por isso mesmo a Universidade possui como desafio a busca pelo conhecimento-emancipação definido por Boaventura Santos (2009, p.10) como: "nesta forma de conhecimento conhecer é reconhecer é progredir no sentido de elevar o outro da condição de objecto à condição de sujeito", portanto os saberes tradicionais inerentes ao artesanato de barro branco aqui 
desvelados se inserem na categoria de sítios simbólicos com a pretensão de conhecimentoemancipação.

Retomando as reflexões desenvolvidas no Manifesto Tocantins (Ward, 2015) resultante do Seminário Internacional da Crise Civilizacional "Distintos Olhares" e as conclusões expressas pelos participantes da Oficina de Avaliação Internacional da Orus, a UFT necessita retomar sua proposta inovadora e transdisciplinar da reforma do pensamento, por meio de uma superação das distâncias entre a cultura científica e a cultura popular, como mencionado por Leonardos (2008):

$\mathrm{Na}$ estratégia de uma universidade nova, brasileira que emerge, o saber universal dialoga com os saberes enraizados na alma nativa e desaparecem as portas departamentais que aprisionam ou disciplinam a alma humana dentro das verdades impostas pela cultura colonizadora (LEONARDOS; COSTA, 2008, p. 106).

O campus de Arraias da UFT tem muito a contribuir com esta retomada da inovação transdisciplinar característica central da constituição da UFT como universidade. Diante de sua riqueza cultural nascida a partir do garimpo do ouro, da emancipação da mão de obra escrava concentrada em seus antigos quilombos, da constituição da cidade povoada de mitos e tradições, o campus de Arraias permite a aventura da universidade que nasce em simbiose com a alma nativa de seus habitantes, a pesquisa etnográfica dos saberes tradicionais dessas comunidades aponta esta perspectiva do olhar.

Mas, para que esta perspectiva de olhar diferentes saberes seja possível é necessário que se constitua as lentes teóricas apropriadas para permitir este contato, somente deste modo podese usufruir das instâncias diferenciadas desta visão. 


\section{AS LENTES TEÓRICAS DE MEU OLHAR: ECOLOGIA DE SABERES E ETNOMATEMÁTICA}

Figura 9: Simetria: tela de Álvaro García López

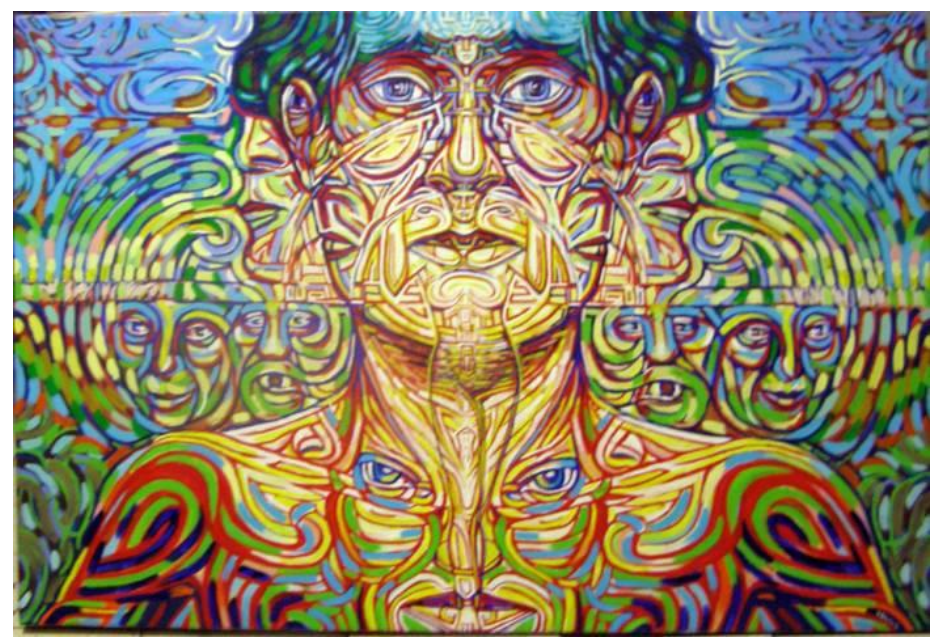

Fonte: Site de busca da internet ${ }^{24}$

\footnotetext{
${ }^{24}$ Disponível em:

https:/www.google.com.br/search?q=etnomatem\%C3\%A1 tica\&espv=2\&biw=1366\&bih=667\&source=lnms\&tb $\mathrm{m}=$ isch\&sa=X\&ved=0ahUKEwjhpqWaoaDLAhWCIZAKHQGZCRQQ_AUIBygC\&dpr=1\#tbm=isch\&q=simet ria+alvaro+garcia\&imgrc=aD0pJyfPPelaPM\%3A. Acesso em 01 mar. 2016.
} 


\subsection{O OLHAR RECOBERTO (OU DESCOBERTO) PELAS LENTES TEÓRICAS}

As lentes teóricas de meu olhar são compostas por duas percepções que se completam, dialogam entre si, criam nuances permitindo: “[...] um novo diálogo do saber integrativo, pluralista, respeitador de outras culturas[...]" (Vergani, 2009, p.263), são elas a Ecologia de Saberes e a Etnomatemática. Como observado por Dias (2010, p.204): "Se o ver é superfície, o olhar é profundidade; se o ver é uma varredura veloz do espaço, a ação do olhar é atravessamento, tem um objetivo, uma mira, é aproximação e ajustamento". À medida que os objetivos vão se clarificando, o ajustamento se faz necessário e este processo de aproximação do meu campo de pesquisa acontece como se fosse um desvendamento, "uma profunda mutação acontece quando passamos da experiência de ver - do olhar - à explicação racional dessa experiência - ao pensamento de ver -, quando passamos da percepção ao juízo" (Chauí, 1988, p.45) por isso as lentes são imprescindíveis.

Se uso lentes teóricas para registrar meu olhar é porque preciso dar sentido, estabelecer critérios, pensar: "o olhar apalpa as coisas, repousa sobre elas, viaja no meio delas, mas delas não se apropria" (Chaúí, 1988, p. 40), neste processo de mediação entre o que é visto e o que é pensado, o espírito se apropria da essência permitindo que o conhecimento se expresse.

\subsection{ECOLOGIA DE SABERES: INSTITUCIONALIZAÇÃO DOS SABERES TRADICIONAIS}

Boaventura Sousa Santos (1999, 2006, 2008) afirma que vivemos um período de transição paradigmática em que a universidade deve proporcionar o reconhecimento de outras formas de saber: " a hegemonia da universidade deixa de residir no carácter único e exclusivo do saber que produz e transmite para passar a residir no carácter único e exclusivo da configuração de saberes que proporciona" (Santos, B., 1999, p. 194), neste sentido o diálogo entre o saber científico e humanístico deve perpassar o cotidiano da universidade, tendo como objetivo um permanente confronto entre diferentes conhecimentos. Confronto não no sentido de embate, onde forças distintas tentam vencer uma batalha, mas confronto no sentido de olhar de frente, face a face, examinando diferenças e semelhanças. O diálogo somente é possível por meio do confronto.

O conhecimento universitário e científico desenvolvido e acumulado ao longo dos últimos séculos e principalmente durante o século XX baseia-se fundamentalmente na disciplinaridade: “[...] cuja autonomia impôs um processo de produção relativamente 
descontextualizado em relação às premências do quotidiano das sociedades"(Santos, B., 2008, p. 28), porém neste contexto de transição paradigmática as mudanças apontam para um processo de transformação do conhecimento universitário em conhecimento pluriversitário (SANTOS, B., 2008).

Para Boaventura Sousa Santos (2008) o conhecimento pluriversitário é contextualizado, inserido na realidade em que atua e por isso mesmo transdisciplinar: "é um conhecimento transdisciplinar que, pela sua própria contextualização, obriga a um diálogo ou confronto com outros tipos de conhecimento" (Santos, B., 2008, p. 29) características inerentes à reforma do pensamento proposta por Edgar Morin (2003, 2009), como denotado por Moraes (2008, p.20): "Mas, para tanto, necessitamos de um pensamento complexo e ecologizante, capaz de religar estes diferentes saberes, bem como as diferentes dimensões da vida".

Como proposta de rompimento com o ideal de uma epistemologia neutra, capaz de produzir no seio da universidade um processo revolucionário, a Ecologia dos Saberes segundo Santos, B. (2008, p.56) deve ser compreendida como uma forma de extensão ao contrário, “[...] de fora para dentro da universidade". A Ecologia de Saberes é um conjunto de epistemologias que permitem adotar posturas completamente distintas do saber especializado, globalizado e por isso mesmo hegemônico que continua existindo na universidade (Santos B., 2006, 2008). Sua proposta estabelece a possibilidade de diálogo entre o saber institucionalizado como científico e os saberes populares e tradicionais silenciados nas vozes anônimas que compõem o cenário fora da universidade.

Para o autor, a Ecologia de Saberes funda-se no princípio de que a injustiça social é fruto da injustiça cognitiva e a partir dessa afirmação elabora 17 teses onde desenvolve os elementos norteadores desse conjunto de epistemologias. Elas apontam para a possibilidade do reconhecimento de saberes não científicos sem descredibilizar os saberes científicos, valorizando a interdependência entre os diferentes saberes. Além disso, reconhece que todo conhecimento tem seus limites internos e externos e que o uso contra hegemônico da ciência moderna deve permitir a exploração destes limites, inclusive na compreensão de que a ciência não responde a todas as questões. A Ecologia de Saberes admite que as práticas da ciência dominante estão vinculadas ao processo de manutenção das distintas desigualdades do mundo contemporâneo e que a sua superação somente será possível por meio do reconhecimento de outros saberes, além do saber científico.

Assentada na ideia pragmática de que “[...] é preciso fazer uma reavaliação das relações concretas na sociedade e na natureza que os diferentes conhecimentos proporcionam" (Santos, 
B., 2006, p.159), a Ecologia de Saberes salienta a importância da preservação da riqueza simbólica contida em saberes ancestrais mantidos por meio da tradição oral.

Segundo Boaventura Santos (2006) a Ecologia de Saberes estabelece uma nova epistemologia polifônica e prismática:

Polifónica, porque os diferentes saberes são simultaneamente partes e totalidades e, tal como numa peça musical, têm desenvolvimentos autónomos, ainda que convergentes. Prismática, porque se cruzam nela múltiplas epistemologias cuja configuração muda consoante a "disposição" dos diferentes saberes numa dada prática de saberes (SANTOS, B.S., 2006, p.161).

Nesta sinfonia musical de saberes proposta por Boaventura Sousa Santos $(2006 ; 2008)$ existe inerente a possibilidade de reformar o pensamento e como consequência permitir à Universidade um novo caminho pois: “a ciência do século XXI deverá religar saberes dispersos, superar dicotomias entre saberes científicos e saberes da tradição e, desse modo, caminhar para algo mais transversal, polivalente, retroalimentado pela dialogia da natureza e cultura [...]" (MORIN; CARVALHO, 2010b, p. 15).

\subsection{ETNOMATEMÁTICA: A GRAMÁTICA DAS FORMAS DE VIDA}

Etnomatemática $^{25}$ é um vocábulo estranho, como diria Vergani (2007, p. 7) ao introduzir o termo em um de seus livros: “A designação de 'etnomatemática' soa estranhamente aos nossos ouvidos: este nome pode evocar um exotismo longínquo que, à primeira vista, parece alheio ao nosso cotidiano", mas esta é apenas a primeira impressão, pois o mundo do dia-a-dia está impregnado de etnomatemática.

A ciência moderna derivada do pensamento grego possui suas raízes estabelecidas no solo da matemática, ela se tornou para a civilização atual a principal ferramenta de desenvolvimento do pensamento racional sendo utilizada pelas demais ciências como a física, a química, a biologia, entre outras. Segundo D’ Ambrósio (1998, p.10):

Enquanto nenhuma religião se universalizou, nenhuma culinária nem medicina se universalizaram, a matemática se universalizou, deslocando todos os demais modos

\footnotetext{
${ }^{25}$ Utilizo a palavra Etnomatemática com a inicial maiúscula como referência as lentes teóricas de minha análise baseadas no pensamento de Ubiratan D’Ambrósio e de Teresa Vergani, em outros contextos opto pela escrita com a inicial minúscula.
} 
de quantificar, de medir, de ordenar, de inferir e servindo de base, se impondo, como modo de pensamento lógico e racional que passou a identificar a própria espécie.

Esta universalização da matemática tem sido muitas vezes questionada, considerando que o paradigma tradicional que a sustenta é essencialmente ocidental, derivado das influências greco-romanas e disseminado por meio de processos de colonização cognitiva, apontado por Santos B. (2006, p 155):

Convertida em conhecimento uno e universal, a ciência moderna ocidental ao mesmo tempo que se constituiu em vibrante e inesgotável fonte de progresso tecnológico e desenvolvimento capitalista, arrasou, marginalizou ou descredibilizou todos os conhecimentos não científicos que lhe eram alternativos, tanto no Norte quanto no Sul. Tenho designado este processo como epistemicídio.

A universalização da matemática ocidental possui raízes profundas na instauração do atual paradigma sócio-cultural, como Jullien (2009) afirma, a característica do universal impõe ruptura e absolutização, ou seja, não se admite nenhuma exceção ao pensamento universal. A noção de que o universal e o uniforme comungam de aspectos semelhantes: "pois tudo sugeriria que o uniforme serve apenas para duplicar o universal e reforçá-lo; que ele se contenta em prolongar seus efeitos e torná-los manifestos” (Jullien, 2009, p.29) indica que a matemática ocidental da forma como estabeleceu seus princípios goza do status de universal, por questões culturais e que a Etnomatemática surge com o propósito de rompimento deste modelo.

D’Ambrosio (2014) também se refere ao processo de disseminação da matemática como ciência ligado diretamente à instauração dos impérios coloniais:

\footnotetext{
Matemática como disciplina emerge do ambiente cultural da bacia do Mediterrâneo e do antigo Iraque (bacia Mesopotâmica). Fora desse ambiente, foi organizada em toda a antiguidade greco-romana e na Idade Média dando origem a uma disciplina, que ficou conhecida como Matemática. Esta foi espalhada pela Europa após o Renascimento e em todo mundo na era dos impérios coloniais europeus (D’AMBROSIO, 2014, p. 22).
}

Outros povos também desenvolveram sistemas de conhecimento diversificados usando para isto métodos de comparação, quantificação, medição e representação em alguma medida semelhantes aos métodos conhecidos como matemáticos (Gerdes, 2014). Lévi-Strauss (1976, p. 30) salienta que: 
ângulo das propriedades comuns que chegamos facilmente às formas de pensamento que nos parecem estranhas.

Ao estabelecer as bases epistemológicas da Etnomatemática centrada num enfoque abrangente da história das ciências, com abordagem na cognição e cultura, D’Ambrosio (1998, 2009, 2014) propôs um programa de pesquisa, no seguinte sentido: "As características lakatosianas deste programa de pesquisa levaram-me a chamá-lo de Programa Etnomatemática" (D’Ambrosio, 2014, p. 20). A adoção do termo programa possui um significado fundamental por estabelecer um vínculo com a pensamento de Imre Lakatos (1922-1974) sobre a pesquisa científica reconhecendo-a como uma dinâmica cultural (Rosa; Orey, 2014) onde "[...] a matemática assume cognitiva e explicitamente o seu caráter transdisciplinar no seio de uma experiência reconhecidamente antropológica" (Vergani, 2007, p. 24). O Programa Etnomatemática propõe o diálogo entre distintas concepções matemáticas, integrando cognição, história, sociologia do conhecimento e epistemologia social possibilitando uma dinâmica entre o saber e o fazer de diferentes culturas.

Para D’Ambrosio (2014) a geração do nome Etnomatemática teve como fundamento as raízes gregas das palavras: ethno significando grupo de mitos e valores culturais compatíveis entre si, techné: arte ou técnica e mathemá: explicação, compreensão, aprendizagem. Dessa forma o vocábulo Etnomatemática significa a arte ou técnica de explicar e conhecer em diferentes ambientes culturais.

A Etnomatemática é uma área de pesquisa ainda jovem, seu surgimento pode ser atribuído à realização de uma seção intitulada "Por que ensinar Matemática?" presidida por D’Ambrosio durante o $3^{\circ}$ Congresso Internacional de Educação Matemática realizado na Alemanha em 1976 (D’Ambrosio, 2014). Oficialmente o termo foi cunhado na palestra de abertura do professor Ubiratan D'Ambrosio no $5^{\circ}$ Congresso Internacional em Educação Matemática na Austrália em 1984 (MIARKA, 2011, p.26).

Segundo Gerdes (1996), neste campo de investigação existiram precursores isolados como R. Wilder que no Congresso Internacional de Matemáticos em 1950, afirmou que não era novo considerar a matemática como elemento cultural: "nas várias culturas humanas são encontrados certos elementos que designamos como matemáticos" (Wilder, 1950 apud Gerdes 1996, p. 106). Assim como o antropólogo L. White que iniciou um estudo sobre a realidade matemática fazendo a seguinte reflexão: "residem as verdades matemáticas no mundo exterior, sendo, portanto, susceptíveis de serem descobertas pelo homem, ou são fruto da invenção do próprio homem?” (White 1956, apud Gerdes, 1996, p.106). Na análise de Gerdes (1996) todos estes estudos não tiveram muito eco na época em que foram realizados, pois a noção de que a 
matemática é universal e completamente desvinculada da cultura foi prevalecente durante toda a primeira metade do século XX.

Existem muitas divergências a propósito do significado do termo e das implicações geradas a partir de tal definição. Em sua tese de doutorado Roger Miarka (2011) realizou entrevistas com cinco pesquisadores conceituados na Etnomatemática: Bill Barton, pesquisador da Nova Zelândia, Paulus Gerdes (Moçambique), Eduardo Sebastiani, Gelsa Knijnik, e Ubiratan D'Ambrosio, pesquisadores brasileiros, e sua investigação desenvolveu-se entre outros aspectos sobre as concepções destes estudiosos acerca da Etnomatemática. Este trabalho aponta convergências no pensamento dos entrevistados, bem como algumas discrepâncias, demonstrando a complexidade dessa região de inquérito.

Segundo Miarka (2011) existem concepções abrangentes para a Etnomatemática, como a proposta por D'Ambrosio (2009, 2014), mas existem as propostas restritivas:

Tal concepção abrangente é criticada por Sebastiani ao considerar que, assumindo-a, o objetivo da etnomatemática se perde, pois, renuncia a um foco específico. Seu modo de ver etnomatemática encontra-se no outro extremo. Para Sebastiani, a matemática deve ser nuclear, e etnomatemática é o estudo da matemática de grupos específicos (MIARKA, 2011, p. 392).

Paulus Gerdes: "[...] concebe a matemática de modo universalizante, mas em constante expansão. Para ele, não faz sentido falar em matemáticas no plural. Vê a etnomatemática como um modo de expandir a matemática, ao atentar-se para práticas culturais” (Miarka, 2011, p. 392). Bill Barton salienta o quanto é importante expandir nossa concepção de matemática ao nos depararmos com diferentes abordagens matemáticas. Sua busca concentra-se em ações que denomina de Sistema QRS (quantidades, relações e espaço) “[...] na tentativa de reconhecer atividades específicas à prática matemática” (2011, p. 392). Gelsa Knijnik considera que a etnomatemática é uma caixa de ferramentas: “[...] que nos possibilita estudar os discursos eurocêntricos que instituem as matemáticas acadêmica e escolar, analisando os efeitos de verdade produzidos por tais discursos e também examinar os jogos de linguagem que constituem diferentes matemáticas [...]" (Knijnik, 2008, p.3) onde é possível recolher instrumentos para criar modelos teóricos para as observações, operando com as ideias etnomatemática e dizendo o que ainda não foi dito (MIARKA, 2011).

O Programa Etnomatemática, como elaborado por Ubiratan D’Ambrosio (2009) recebeu ao longo dos anos contribuições em suas diferentes dimensões, dependendo do contexto e do pesquisador responsável, agregou aspectos distintos, porém Miarka (2011) elenca 
três aspectos invariantes na fala dos 5 pesquisadores entrevistados sobre a pesquisa etnomatemática: o respeito ao outro, a presença do diálogo e a importância do conhecimento da língua do grupo cultural estudado (MIARKA, 2011, p. 394).

A Etnomatemática deriva do pressuposto de que sociedade, cognição e cultura estão intrinsecamente ligadas, ou seja, "a matemática é uma atividade universal, é uma atividade pancultural e pan-humana. Em todas as culturas o pensamento matemático tem tido lugar, tanto duma maneira espontânea como duma maneira organizada [...]" (Gerdes, 2010, p. 159), com base na relação entre estes três eixos é que a Etnomatemática se constitui como campo de investigação e como proposta de uma educação múltipla e universalizante (Farias, C.; Mendes, 2014), correspondendo à proposição de que existe a necessidade de um conhecimento matemático local tanto quanto o conhecimento matemático global, ou seja: "[...] a Etnomatemática desenvolveu formas de conhecer e analisar as diversas epistemologias matemáticas operando nos seus contextos culturais" (MOREIRA, 2008, p.6).

Neste trabalho utilizo como referência a definição de Etnomatemática elaborada por D'Ambrosio:

Etnomatemática é a matemática praticada por grupos culturais, tais como comunidades urbanas e rurais, grupos de trabalhadores, classes profissionais, crianças de uma certa faixa etária, sociedades indígenas, e tantos outros grupos que se identificam por objetivos e tradições comuns aos grupos (D'AMBROSIO, 2009, p.45).

Como também norteio minhas análises utilizando as contribuições de Teresa Vergani (1995, 2007, 2009) à área. As lentes teóricas de meu olhar se valem da fala poeticamente encantadora dessa pesquisadora que tece uma teia entre ciência, arte e filosofia: "A etnomatemática nasceu decidida e escutar/pensar com a amplidão dos olhos e a falar/operar com a clarividência de uma nova visão" (VERGANI, 2009, p.220).

Sob estas lentes teóricas, da Etnomatemática na perspectiva D’Ambrosiana e da Ecologia de Saberes, oriento as reflexões acerca das observações realizadas durante minha pesquisa etnográfica com as louceiras de Arraias. 


\section{LOUCEIRAS DE ARRAIAS: ETNOGRAFIA DO BARRO}

Figura 10: Louças de Dona Andrelina

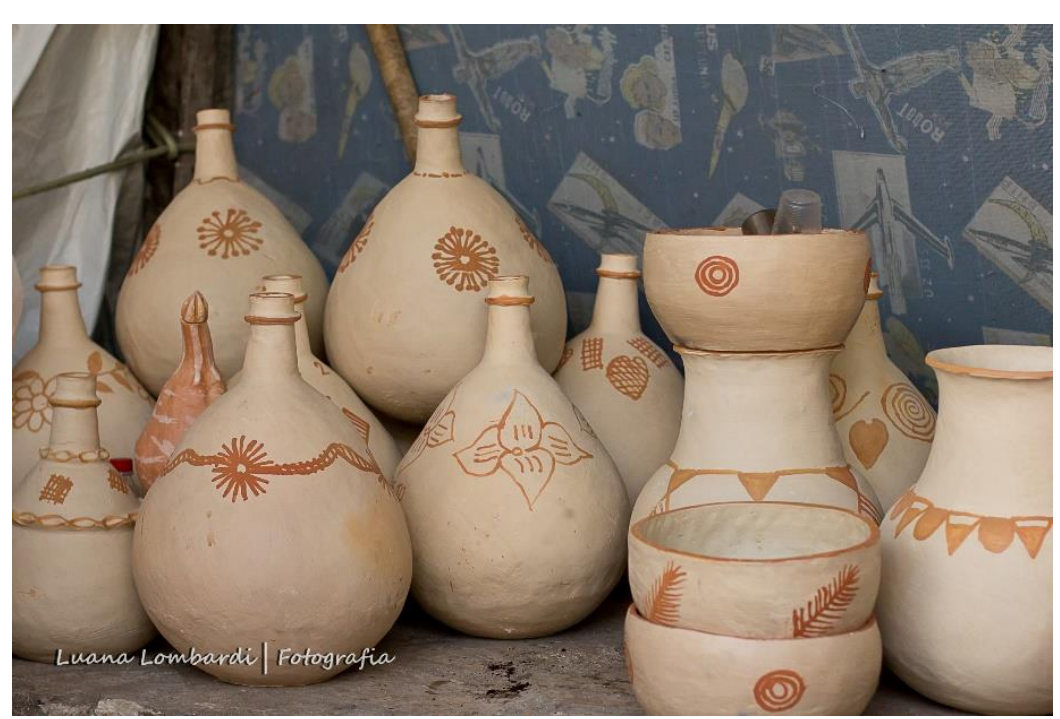

Fonte: Acervo particular Luana Lombardi 


\title{
4.1 OLHAR ETNOGRÁFICO: A BUSCA PELO SIGNIFICADO
}

\begin{abstract}
O olho, fronteira móvel e aberta entre o mundo externo e o sujeito, tanto recebe estímulos luminosos (logo, pode ver, ainda que involuntariamente) quanto se move à procura de alguma coisa, que o sujeito irá distinguir, conhecer ou reconhecer, recortar do contínuo das imagens, medir, definir, caracterizar, interpretar, em suma, pensar (Alfredo Bosi, 1988).
\end{abstract}

O artesanato de cerâmica de barro branco produzido no município de Arraias, Tocantins, é dotado de uma beleza estética e geométrica expresso na sabedoria popular como uma beleza que "salta aos olhos". O processo de fabricação é manual e a transmissão do conhecimento ocorre por meio da tradição oral, "a oralidade precede e sustenta a racionalidade. É a partir deste laço que ciência e tradição se cruzam, se re-conhecem" (Vergani, 2002 apud Almeida, 2010, p. 120) e este conhecimento encontra-se ameaçado de extinção por diversas razões.

Apenas duas mulheres continuam confeccionando as louças e mantendo esta tradição viva, são elas Dona Pretinha e Dona Dona duas senhoras com idades entre sessenta e setenta anos, cheias de sabedoria e experiência que tiveram suas vidas marcadas por sofrimentos e batalhas diárias tornando-se as últimas artesãs de uma arte que desaparece a cada dia. Seu ofício transformado em potes, botijas, fruteiras, gamelas, foi construído num processo de aprendizado baseado na observação do fazer de suas matriarcas que há muitos anos vendiam o produto de sua labuta em pequenas feiras da região, em armazéns na cidade ou no antigo aeroporto onde os aviões paravam para abastecer e continuar seu percurso.

A história do artesanato de barro branco dessas duas senhoras mistura-se a história da cidade de Arraias, onde as transformações dos últimos anos e décadas alteraram as edificações antigas, modificaram a paisagem, mesclando o novo e o antigo, numa simbiose prosaica em que a comunidade muitas vezes parece esquecer-se de suas origens escondida no tempo da mineração do ouro mantida com mão de obra escrava e em outras tantas vezes se apega às antigas tradições para enfrentar os desafios cotidianos.

A cerâmica de barro branco, totalmente artesanal, pintada com argila colorida, confeccionada com o barro subtraído às escondidas de algumas fazendas da região, vendida à beira da estrada "de rodagem", é fruto de um trabalho singular, marcado pela preservação de saberes tradicionais: “A cultura envolve não só uma concepção do mundo que se traduz em conhecimentos e configurações de acção, mas o travejamento de um pensar e de um sentir articulado num sistema dinâmico de significações simbólicas" (Vergani, 1995, p. 24), a cultura 
inerente à preservação destes saberes reconta o passado histórico dessa pequena cidade do interior do Estado do Tocantins em que a presença da universidade abriu a perspectiva do novo, apontando para um caminho de transformação cognitiva e por isso mesmo social.

A metodologia utilizada em minha pesquisa de campo foi etnográfica no sentido destacado por Lévi-Strauss (1976, p. 285): “[...] o que todo etnólogo experimenta fazer para culturas diferentes: por-se no lugar dos homens que nela vivem, compreender-lhes as intenções no seu princípio e no seu ritmo, perceber uma época ou uma cultura como um conjunto significante", dessa forma estabeleci uma relação de convívio com as duas senhoras em seu ambiente cotidiano, registrando sua labuta, seus saberes e seus fazeres. Este registro se deu por meio de gravações de nossas conversas, filmagem do processo de produção, mas principalmente através do escutar, ou seja: "que sentido poderá ter um trabalho de campo se ele não se investir - com suas capacidades cognitivas, as suas emoções, o seu corpo, a sua sensibilidade - no meio que o acolhe?" (Vergani, 1995, p. 31), este convívio estendeu-se, aproximadamente, pelo período de três anos, em que as visitas aconteceram numa regularidade variável, em algumas épocas do ano todos os meses e em outras num espaço de dois a três meses.

Mergulhar no universo das louceiras de Arraias foi enriquecedor, tanto do ponto de vista etnográfico como também etnomatemático, considerando que: “é este espelho onipresente do fenômeno humano que a etnomatemática interroga quando busca uma compreensão autêntica das alteridades com as quais pretende relacionar" (Vergani, 2009, p. 222), tomando o registro de seus fazeres e saberes como testemunhas vivas da tradição oral da cerâmica de barro branco intrincada em suas vidas, ou seja:

O olhar etnográfico é um exercício diário para o pesquisador que adota a atitude descritiva, não só em termos teórico-metodológicos, mas éticos e políticos de aprender sobre os sentidos e significados da ontologia humana e da sua dinâmica cultural (SÁ, 2012, p. 76).

\subsection{AS LOUCEIRAS DE ARRAIAS: HISTÓRIAS DE VIDA ENTRELAÇADAS AO BARRO}

Minha aproximação com as mulheres artesãs do barro se deu num processo lento e constante característico da pesquisa etnográfica, ou seja: "para a etnopesquisa, o método é o 
prolongamento das escolhas do pesquisador, ao tratar com as 'intimidades' do fenômeno pesquisado, vinculando-as às suas" (Macedo, 2012, p. 28). O método utilizado foi o convívio periódico com a realidade cotidiana dessas senhoras, na tentativa de registrar o processo de criação artesanal, mas também na busca de vivenciar os problemas básicos ligados à manutenção dessa tradição, como a venda das peças e as dificuldades em coletar a matéria prima: o barro. Em minhas visitas utilizei a gravação das conversas em algumas vezes acompanhada por filmagem do processo de criação das peças, em outros momentos não houve nenhum tipo de registro, apenas as impressões captadas foram descritas num diário de campo: “[...] o escrever passa a ser parte quase indissociável do nosso pensamento, uma vez que o ato de escrever é simultâneo ao ato de pensar" (OLIVEIRA, ROBERTO, 2000, p. 31).

Dona Dona, batizada Andrelina tem 70 anos, estatura baixa, pele negra, olhar meigo e condescendente, sua fala mansa, é sempre envolvida em sorrisos. Meu primeiro contato com ela e seu esposo foi há cerca de 5 anos, quando o Núcleo de Estudos para o desenvolvimento do Turismo Sustentável do Sudeste Tocantinense da UFT (Nedetur), do qual faço parte, tentou organizar uma associação de artesãos no município de Arraias com vistas à ocupação do espaço de comercialização de produtos construído para este fim. As reuniões com os artesãos aconteceram algumas vezes com a presença de Dona Andrelina e seu esposo Sr. Pedro, porém a associação não foi criada e o Núcleo desistiu deste projeto.

Quando a procurei convidando-a para participar de minha pesquisa mostrou-se receptiva, mesmo estando num período de trabalho intenso. Uma vez ao ano ela produz grande quantidade de louças para vender nos festejos da padroeira da cidade, sua produção fica exposta em uma barraca cedida pela prefeitura em meio ao comércio itinerante que se espalha pelas ruas íngremes do centro, por aproximadamente uma semana no início do mês de setembro.

Foi nessa época, em agosto de 2014 que a procurei na pequena propriedade localizada no Pé do Morro distante 6 quilômetros da cidade, onde vivia com seu esposo e neto e recebi sua anuência em participar da pesquisa. A pequena propriedade do Pé do Morro pertence ao poder público municipal, e no passado a casa aonde eles viviam era uma escola municipal, aos fundos da casa passa um riacho que abastece o sítio. A energia elétrica é fornecida por um gerador movido à gasolina.

Ela estava concluindo a produção que ia ser comercializada durante os festejos e sua filha Corinha a ajudava na finalização das peças, colocando pescoço em alguma botija ou então simplesmente alisando uma peça. Dona Andrelina à medida que produzia seu artesanato, 
respondia minhas perguntas e contava a sua história de vida, como pontuado por Ecléa Bosi (1994, p. 81) "Uma lembrança é diamante bruto que precisa ser lapidado pelo espírito. Sem o trabalho da reflexão e da localização, seria uma imagem fugidia. O sentimento também precisa acompanhá-la para que ela não seja uma repetição do estado antigo, mas uma reaparição".

Chalub Martins (2002) citando Bosi (1994) define que a memória não é sonho, ela é reconstruída pelo presente, marcada pelas experiências vividas e transformadas ao longo do tempo, ou seja, “[...] assim, reafirma a estreita relação entre a vida de hoje e o processo de reconstrução do passado" (Chalub Martins, 2002, p.5). Quando Dona Andrelina revive seus tempos de menina lembra de muito sofrimento: "Aí eu fiquei por aqui mesmo, minha mãe me criava, minha mãe num tinha marido. Oh vida assim sofrida! Criada na casa dos otros, era na casa, na rua, era em Campos Belos, era aqui em Arraias" (INFORMAÇÃO VERBAL) ${ }^{26}$.

Em seus relatos relembra que sua história com o barro começou há muito tempo, desde a idade de oito anos:

Idade de 8 ano, eu era menina, minha mãe fazia, eu rumava pra ela as coisa, o barro, deixava ela prontinha, aí.....ela ia pra rua vendê os pote, levava na cabeça, chegava lá na rua vendia tudo. Aqueles povo de armazém, ota hora era gente mesmo na rua, comprava pra levá pra fazenda, ota hora era pra lá mesmo, pra ir pra rua mesmo. Aí eu fazia as "zuinha", pequenininha levava, vendia tudo também. Vendia, comprava roupa, comprava calçado pra mim. Aí eu ficava doida pra fazê mais e dessa história segui a vida, né? (INFORMAÇÃO VERBAL) ${ }^{27}$.

Sua infância sofrida ao lado de sua mãe teve alguns momentos mais serenos como por exemplo quando foi morar na casa de uma senhora em Arraias, esposa de seu tio que: “[...] perdeu a cabeça e sumiu no mundo e ela ficou apaixonada por ele" (informação verbal) ${ }^{28}$. Esta senhora implorou a sua mãe para poder levá-la para sua companhia: "essa menina cê tem que me dá ela! Pra ficá mais eu, que eu tô sozinha e ela parece muito o marido meu. Aí eu falei: ai, ai, meu Deus do céu!"29. Viveu na casa dessa senhora a quem chamava de Mãe Rosa durante uns seis anos, neste período ajudava o padre da cidade nos afazeres domésticos, cuidando da limpeza de sua casa e da igreja. Voltou a morar com sua mãe para ajudá-la no trabalho, inclusive da roça e aos 16 anos casou-se com Seu Pedro, pela insistência de sua mãe, que não desejava ver suas filhas "perdidas".

\footnotetext{
${ }^{26}$ Conversa com Dona Andrelina Ferreira Flores em 26 ago. 2014 em sua residência no Pé do Morro, zona rural de Arraias

${ }^{27}$ Idem, 2014.

${ }^{28}$ Ibid., 2014.

${ }^{29}$ Ibid., 2014.
} 
Mãe de quatorze filhos, criados com o seu trabalho na cerâmica, em suas palavras: "Tudo trabalhando nesse serviço aqui, oh! Tudo vivo. Tudo sadio e tudo gordo" (informação verbal $)^{30}$. Seu esposo e o seu neto são seus auxiliares no trato do barro, Seu Pedro vai ao barreiro arrancar o barro, depois seu neto prepara a argila socando com a mão do pilão e por fim sessa (coa) na peneira deixando-o pronto para o uso.

A sua vida foi marcada pelo trabalho no barro, na roça, na criação dos seus catorze filhos, mesmo agora em idade avançada, portadora de várias doenças, fruto dos longos períodos em pé modelando as louças, não para de trabalhar: "Eu num gosto de ficar é à toa, fui criada assim, né?” (INFORMAÇÃO VERBAL) ${ }^{31}$.

Ao longo dos anos, as vendas do artesanato diminuíram e atualmente são concentradas em alguns períodos, principalmente nos festejos de Nossa Senhora dos Remédios, padroeira da cidade, no início do mês de setembro e na feira do agricultor familiar no dia $1^{\circ}$ de agosto, em comemoração ao aniversário da cidade. Em sua análise: as pessoas da cidade enjoaram do artesanato de barro branco, pois em quase todas as casas dos moradores mais antigos existe uma botija, uma gamela ou uma panela produzida por ela ou por sua concorrente, por isso a maioria dos seus clientes são moradores de outras cidades. No passado suas louças foram levadas para muitas cidades da região como Brasília, Goiânia e Palmas indo até mesmo para a Itália, motivo de seu orgulho, mas a fama não lhe trouxe nenhum benefício, nenhuma vantagem.

Dona Dona foi alfabetizada, mas afirma ter aprendido quase nada, em suas palavras: "Eu estudei um pouco, mais muito pouco. Quando eu fui já tava grandona, aí começava a estudar largava e ia trabaiá, aí fiquei nessa rotina" (informação verbal) ${ }^{32}$. Voltou a estudar há pouco tempo, matriculou-se na Educação de Jovens e Adultos (EJA) numa escola urbana, mas desistiu por causa da distância e pela falta de condução. Mudou-se para uma casa "na rua", mas diz estar muito adoentada para conseguir estudar.

Nenhum dos seus catorze filhos aprendeu o ofício completamente, alguns se disponibilizam a ajudá-la em etapas do processo, como enformar ou pintar as peças, porém segundo suas observações eles não conseguem aperfeiçoar as informações, talvez por falta de interesse, gerado inclusive pela pouca valorização comercial desse trabalho na comunidade.

Dona Lucrécia, conhecida como Pretinha é uma senhora negra, magra, desconfiada e arredia. Moradora de uma propriedade às margens da Rodovia TO 050, nas proximidades do

\footnotetext{
${ }^{30}$ Ibid., 2014.

${ }^{31}$ Conversa com Dona Andrelina Ferreira Flores em 26 ago. 2014 em sua residência no Pé do Morro, zona rural de Arraias.

${ }^{32}$ Idem, 2014
} 
Posto de Fiscalização Estadual, distante 14 km de Arraias. Seu Sítio não possui água, nem uma pequena mina nem um córrego, depende apenas dos galões buscados em outras propriedades transportados de carro que são contratados para este fim, além de contar com duas cisternas para recolher as águas das chuvas que foram instaladas por meio de um programa do governo estadual. Nos períodos de seca prolongada a prefeitura de Arraias disponibiliza caminhões-pipa para abastecer as propriedades, como a de Dona Pretinha, mas, o dia-a-dia é de muita precariedade por falta dessa fonte de vida.

Visitei sua propriedade em setembro de 2012, apresentei-me e falei rapidamente sobre minha pesquisa a respeito de sua produção artesanal. Ela me acolheu com alegria e mostroume orgulhosa as reportagens sobre seu trabalho, no Almanaque Cultural e no Jornal do Tocantins, levou-me até o forno onde queima as louças (figura 14), apresentou-me o torno manual onde modela as peças e os sabugos de milho que são utilizados para alisar as peças. Sua recepção foi calorosa neste primeiro momento.

Ao longo do período de minhas visitas para realização da pesquisa, nem sempre fui bem acolhida, seu jeito esquivo e cismado, típico do povo sertanejo, por vezes ficava a me observar, sem muito falar. Porém, o motivo central de sua desconfiança é por causa de sua cunhada também artesã: Dona Andrelina. Dona Pretinha e Seu Pedro são irmãos. Apesar dos laços sanguíneos estas famílias não se relacionam de forma alguma, ao contrário vivem uma relação recíproca de intriga e inimizade, existindo inclusive rivalidade em relação a produção de seu artesanato: uma critica as louças da outra.

Dona Pretinha tem 64 anos, também se casou muito nova aos 17 anos e separou-se pouco tempo depois pois "seu marido ficou virado na cantoria e saiu pro mundo" (informação verbal) ${ }^{33}$. Teve 19 filhos, criou 12 e atualmente tem 10, dois filhos faleceram depois de adultos. Todos os partos foram feitos por ela, sozinha, nada de hospital, nem de parteira, ela paria, cortava o umbigo dos filhos e os amamentava em seguida, segundo suas lembranças cheias de detalhes. Casada com o Seu José Messias há muitos anos, recorda-se que no tempo que se uniram ele tinha apenas 16 anos, segundo suas palavras: "peguei ele pra acabá de criar" (informação verbal) ${ }^{34}$, tiveram 8 filhos, sendo o último parto de gêmeos, hoje dois rapazes com 18 anos. Ele tornou-se seu parceiro no trabalho com a cerâmica, arranca o barro soca, sessa (coa) e o deixa preparado para a confecção do artesanato.

\footnotetext{
${ }^{33}$ Conversa com Dona Lucrécia Bento Filho em 25 fev. 2015, em sua propriedade no Sítio Novo, rodovia TO 050 .

${ }^{34}$ Idem, 2015.
} 
A venda das louças é sua principal atividade econômica, as peças ficam expostas numa velha prateleira de madeira em frente à sua propriedade à beira da rodovia estadual TO 050 . Mesmo em meio a todas as dificuldades advindas da idade e da saúde fragilizada, Dona Pretinha sempre possui louças à venda em sua prateleira, além do mais sua netinha Débora a ajuda no ofício e ao que tudo indica está se tornando sua aprendiz na arte de trabalhar o barro. Ela foi criada pela avó e por meio da observação do ofício fabrica pequenas botijas que já estão sendo comercializadas, como observado por Maria Acselrad: "o aprendiz é o verdadeiro protagonista de seu processo de construção de conhecimento" (ACSELRAD, 2011, p. 8).

Dona Pretinha afirma em nossas conversas que se tornou famosa por causa das louças, muitas pessoas, principalmente jornalistas, procuram-na para entrevistá-la, fotografam-na como também suas peças, gravam vídeos de seu trabalho, mas tudo isso não representou nenhuma melhoria em sua qualidade de vida, continua sofrendo pela falta de energia elétrica e de água em sua propriedade, por isso colocou o sítio à venda, frequentemente em nossas conversas afirma que venderá a terra e mudará para outro local, deixará o trabalho com as louças, que segundo sua reflexão não the trouxe benefício, principalmente em suas condições materiais. Sua casa é construída com tijolo de adobe e chão batido, não possui instalações sanitárias, mesmo possuindo um aparelho de televisão não tem como assisti-la por causa da ausência de energia elétrica, queixa-se constantemente da falta de conforto em sua vida.

Dona Pretinha praticamente não frequentou a escola, me diz que foi à escola quando já era mocinha e nada aprendeu, apenas escreve seu primeiro nome, mesmo possuindo um aparelho celular depende de seus familiares para realizar ligações por desconhecer os números.

As vidas de Dona Pretinha e de Dona Dona são enredadas numa mesma narrativa, aprenderam o ofício do artesanato com suas mães por meio da observação e da prática, casaramse novas, pouco frequentaram a escola, tiveram muitos filhos, vivem dificuldades semelhantes em relação a obtenção do barro e a comercialização das peças. Além do mais, a fama de suas louças lhes rendeu reportagens em jornais de circulação regional, vídeos em programas de televisão, artigos em livros, porém não lhes proporcionou qualidade de vida, nem tampouco o reconhecimento da comunidade local.

A herança do saber presente na confecção das louças de barro não conseguiu se estabelecer em suas famílias, mesmo com a importância que os seus trabalhos artesanais tiveram na criação dos seus filhos, sendo uma ameaça à tradição do barro em Arraias, levando em consideração a idade das duas louceiras e a falta de interesse de seus familiares em dar continuidade a esta tradição. Dona Andrelina afirma que todas as mulheres de sua família 
produziam o artesanato no passado, suas tias: Crispiana, Biana e Joana além de sua mãe, porém todas já são falecidas e nenhum de seus filhos deu continuidade a esta tradição.

É possível que este saber tradicional não seja passível de transmissão justamente por representar o que Larossa apud Macedo, 2012, p. 101, aponta:

O saber da experiência se dá na relação do conhecimento e a vida humana[...] se a experiência é o que nos acontece e se o saber da experiência tem a ver com a elaboração do sentido ou o sem-sentido do que nos acontece, trata-se de um saber finito, ligado à existência de um Ser individual ou coletivo [...]

Para Acselrad (2011) a transmissão de saberes se articula em duas dimensões, uma envolvendo o contexto cultural e histórico e a outra à capacidade dos agentes das culturas populares e tradicionais em desenvolver sua criatividade na elaboração de estratégias de ensino aprendizagem que possam garantir a manutenção e a evolução dessa tradição. No processo artesanal de produção das louças é possível percebermos que a transmissão desses saberes acontece por observação, não existindo uma metodologia formal para estabelecer o aprendizado, considerando a afirmação das duas artesãs de que este conhecimento não pode ser ensinado pois as outras pessoas não aprendem.

As louceiras de hoje foram aprendizes no passado e o seu aprendizado está inserido nas características de dom especial, reservado apenas a algumas pessoas da comunidade, como apontado por Acselrad (2011, p.7):

\footnotetext{
A referência a uma atmosfera divina revela uma característica recorrente na construção deste aprendizado. Estratégia de superação das adversidades cotidianas e estruturais, o divino vem associado à noção de dom e reforça o caráter da construção de aprendizado como missão.
}

Este dom ou missão segundo Dona Pretinha não pode ser ensinado: "Isso aqui se a gente ensiná, não aprende não, isso aqui é a inteligência da cabeça da gente" (informação verbal) ${ }^{35}$. Portanto, mesmo que os filhos de Dona Andrelina tenham aprendido etapas do processo na confecção das louças principalmente para ajudá-la nos períodos de intensa produção não é o suficiente para garantir a transmissão desses saberes para as futuras gerações. E no caso de Dona Pretinha apenas sua netinha de 12 anos pode ser considerada aprendiz do ofício, apesar de que houve no passado uma filha que dominou a técnica e que segundo ela conseguia copiar

\footnotetext{
${ }^{35}$ Conversa com Dona Pretinha 17 out. 2014, em sua propriedade no Sítio Novo, rodovia TO 050.
} 
modelos diferentes, como por exemplo construir uma galinha de barro, porém esta filha envolveu-se com álcool e drogas e ela não a aceitou como sua colaboradora.

Elas aprenderam a arte com suas mães, tias e avós, mas seus descendentes, em alguns casos, dominam alguma etapa do processo, como a pintura ou a modelagem das peças, porém isso não configura a sobrevivência dessa arte na comunidade.

Segundo Pedreira et al. (2012) na área rural do município de Paranã, cidade localizada a cerca de $120 \mathrm{~km}$ de Arraias, a Senhora Izabel Francisco juntamente com seu esposo Enedino Quirino também se dedicam à confecção das louças de barro usando técnicas parecidas com as utilizadas por Dona Pretinha e Dona Andrelina, porém possuindo suas especificidades, “O processo de ensino-aprendizagem que levou à formação das artesãs foi relativamente parecido, mas a materialização desses saberes tem suas particularidades, suas características, seus detalhes e acumula tradições [...]" (PEDREIRA et al., 2011, p. 139).

\title{
4.3 ARTESANATO: LINGUAGEM DE FORMAS DE ESPAÇO ANCORADA NOS SABERES DA TRADIÇÃO
}

\begin{abstract}
Pois ao dar forma ao jarro, o homem encontra formas de compreensão de sua própria vida, ordenando-se e moldando-se espiritualmente. As formas de ordenação implicam um depoimento do artista/artesão sobre suas vivências e sobre o sentido do ser: é isto que nos comove tão profundamente nas obras de arte (Faya Ostrower, 1988)
\end{abstract}

As louças de Dona Pretinha e de Dona Dona são formas ordenadas, testemunhas silenciosas de suas vidas, desvendando o tecido sensível de suas criações e recriações num processo denominado por Ostrower (1988, p. 172) de metalinguagem: “[...] que serve de referencial a todos os modos de comunicação humana: é a linguagem das formas do espaço". Para a autora todas as pessoas passam pelas mesmas experiências do espaço em seu processo de crescimento e de construção de sua identidade pessoal, tal processo tem início logo após o nascimento quando a criança utiliza todo o corpo para aprender a se movimentar, o processo se estende na observação das diferentes formas espaciais, no aprendizado de sentar, engatinhar e andar. A metalinguagem se constrói nesta relação intensa com o espaço: "Fornecendo as imagens para a nossa imaginação, o espaço se torna o mediador entre a experiência e a expressão. Só podemos pensar e imaginar mediante imagens do espaço” (1988, p. 173). 
A construção das formas artesanais das louceiras de Arraias tem início com a retirada do barro, num processo arriscado, levando em consideração sua clandestinidade, segundo suas informações os donos das fazendas da região aonde a argila é abundante não autorizam sua retirada. Resta aos seus esposos, os responsáveis por esta etapa do processo, arriscarem-se a "arrancar" a argila muitas vezes às escondidas ou apenas com a autorização dos vaqueiros, responsáveis pelas fazendas.

O barro é colocado no quintal, sobre o couro curtido, depois de seco, esmigalhado é socado com a mão do pilão até virar uma farinha fina, então é passado na peneira para a retirada das impurezas, depois de molhado está pronto para ser transformado pelas mãos das artesãs.

As formas dos potes, botijas e fruteiras das artesãs de Arraias nascem a partir de uma chapa de barro, redonda, que após ser amassada, primeiramente com a mão do pilão e depois com a mão da artesã é colocada em volta da forma que lhe servirá de molde (figura 10). Estes moldes foram produzidos ao longo dos anos pelas artesãs e acompanham seu processo de criação artesanal, são compostos por botijas, potes e panelas que por algum motivo foram rejeitados para a comercialização. A nova peça vai surgindo vagarosamente à medida que as mãos ágeis destas senhoras modelam o barro úmido, em torno do molde, "forma significa, sempre: estrutura, organização, ordenação" (Ostrower, 1988, p. 174). Este processo é denominado por elas de enformar o barro.

Figura 11: Dona Andrelina modelando a chapa de barro

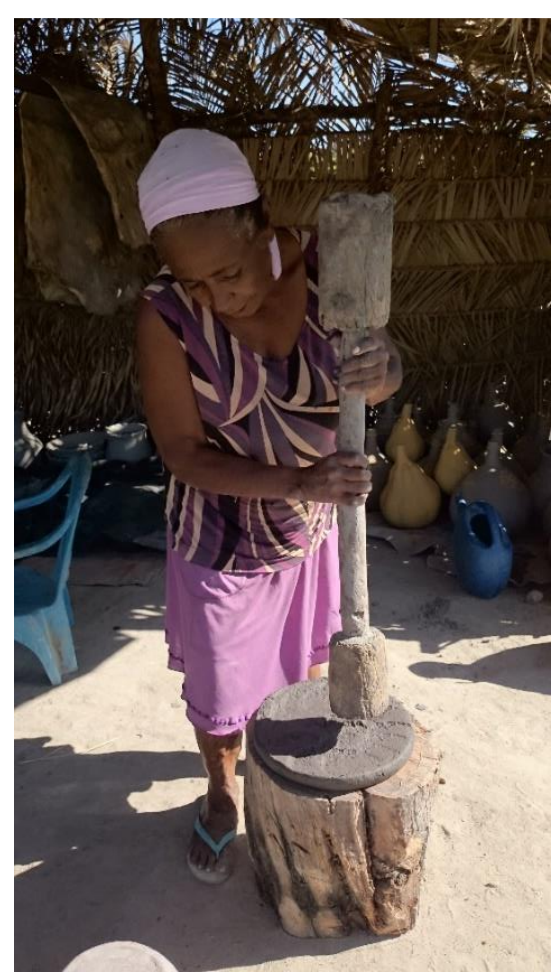

Fonte: Acervo da autora 
Após o barro ter sido enformado no molde, passa-se ao processo de alisamento da peça com o auxílio do sabugo de milho, estes também são escolhidos pelas artesãs por determinadas qualidades identificadas no trato com o barro e uma pequena faca é utilizada para fazer pequenos furos, segundo Dona Andrelina: "Eu vou tirar os ventinhos aqui. Vê? Essas boinhas assim oh! É vento do barro" (informação verbal) ${ }^{36}$. Elas utilizam um balde com água do lado do torno artesanal, onde constantemente o sabugo é mergulhado, dessa forma a peça vai sendo alisada e quando o sabugo encontra algum caroço de barro duro, é retirado com a faca e em seu lugar um pedacinho de barro reposto, estes caroços são chamados por Dona Andrelina de "bidonguinhos".

O torno artesanal (figura 11) é constituído por um tronco de madeira onde uma pequena tábua é inserida por meio de um prego, dessa forma ela gira em torno da base, possibilitando o trabalho de modelagem das louças.

Figura 12: Torno artesanal de Dona Andrelina

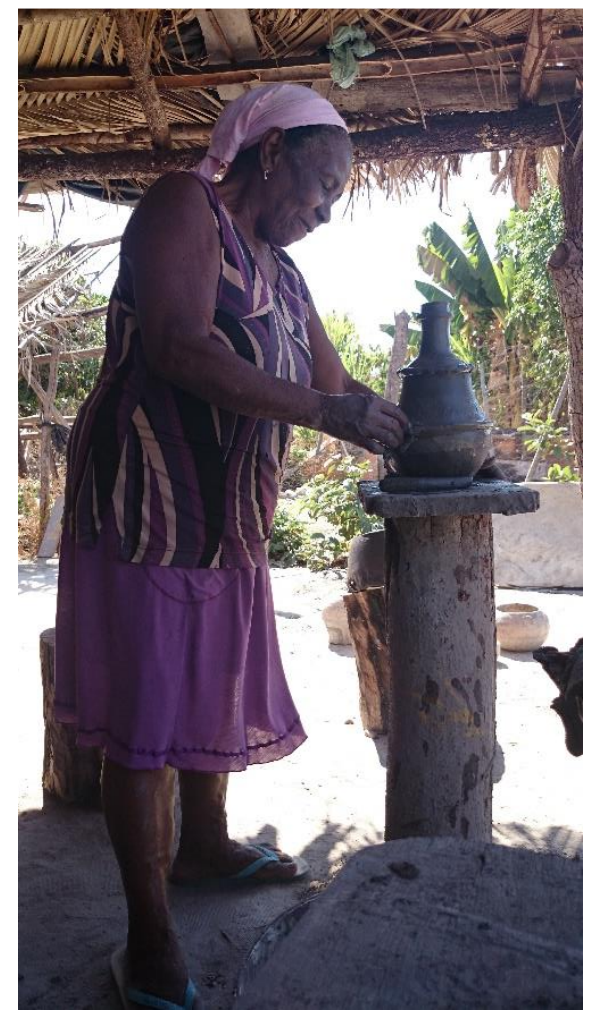

Fonte: Acervo da autora

${ }^{36}$ Conversa com Dona Andrelina Ferreira Flores em 26 ago. 2014 em sua residência no Pé do Morro, zona rural de Arraias. 
O processo de alisamento é finalizado por uma nova etapa quando um pedaço de pano molhado na água do balde é passado em toda a peça, enquanto a artesã gira o torno com uma das mãos, a outra mão passa o pano molhado sobre o barro. Depois disso a peça é colocada para secar em alguns casos na sombra ou então ao sol, ainda sobre o molde que lhe dará a forma geométrica. Dependendo da intensidade do calor do sol, a peça sai da exposição entre meia hora a quarenta minutos e é retirada do molde (figura 12). Na realização desta etapa, a faca é novamente utilizada para fazer pequenos cortes na futura louça com o propósito de facilitar a retirada do molde.

Neste momento a louça vai novamente para a tábua e passa por um processo de reconstrução, onde novas tiras de barro são coladas ao seu corpo, proporcionando o formato desejado, esta etapa utiliza a técnica do entrelaçamento espiral, quando pequenos rolos de barro são inseridos na peça (figura 12). Estes remendos são colocados na peça e o alisamento com o pano embebido na água recomeça, com o propósito de colar estes novos pedaços ao corpo da louça. Dependendo da peça, ela pode receber novas tiras de barro por toda a sua circunferência, como as botijas pequenas e decoradas, que recebem as tiras e onde os dedos das artesãs são simetricamente gravados, no formato de uma renda.

Figura 13: Técnica do entrelaçamento em espiral

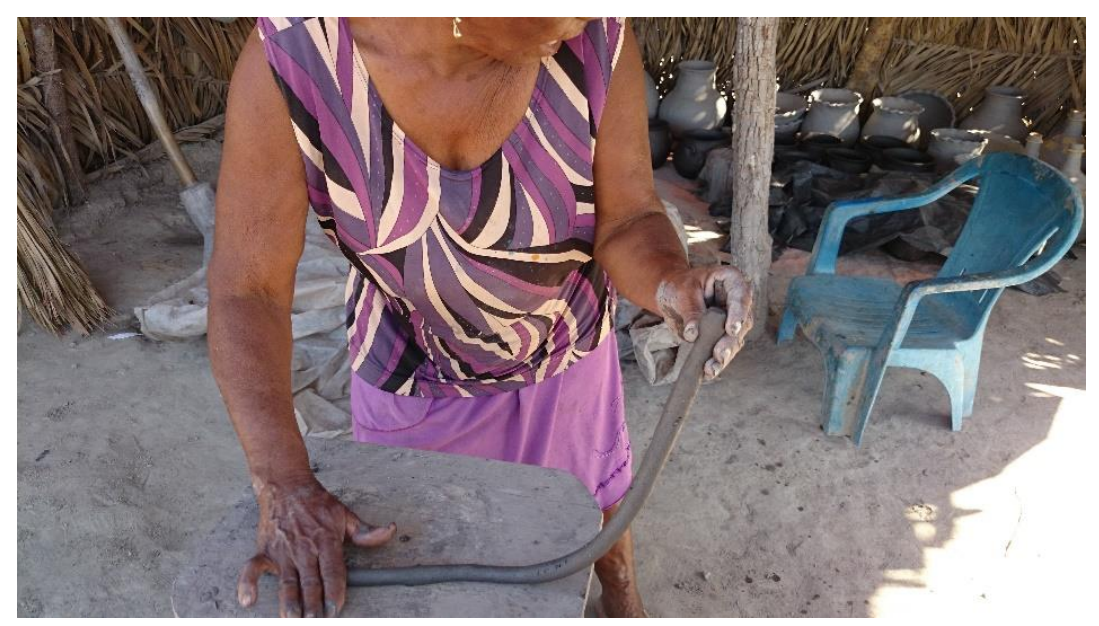

Fonte: Acervo da autora 
Figura 14: Processo de secagem das louças ao sol

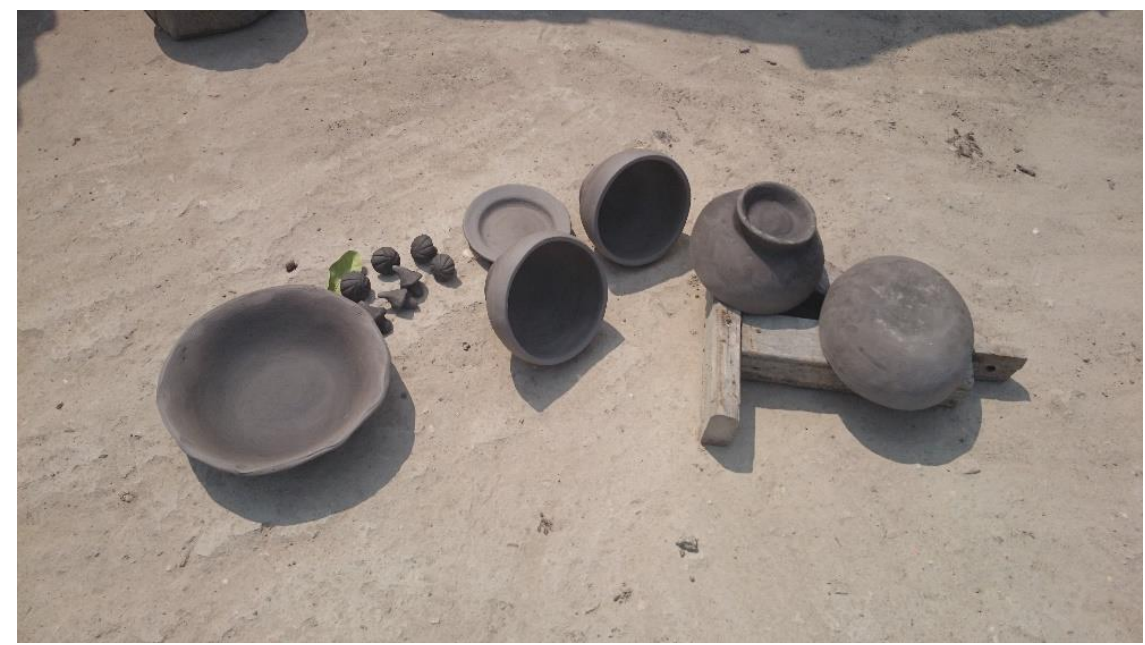

Fonte: Acervo da autora

Quando a peça pronta se encontra completamente seca inicia-se o processo da pintura com argila (figura 13). A argila utilizada na pintura das peças é retirada da barranca dos rios e córregos, possui uma coloração avermelhada e misturada com água é aplicada na peça por meio de um pincel feito de palha de buriti.

O barro de pintar é outro barro, a gente ranja ele no barranco de rio, assim alguma tira amarelinha, vermeinha, a gente vai tirando aquelas manchinha, trais, junta, machuca assim com um pauzinho, móia ela tudo, põe num poquinho de água, mexe com a mão, põe no saco de linhagem, coa ela pra num ficá canjica. Aqui é coado num saco de linhagem! (INFORMAÇÃO VERBAL) ${ }^{37}$.

Os desenhos nas peças são variados: flores, estrelas, corações, peixes. Durante a pesquisa questionei a Dona Dona sobre a inspiração para fazer os desenhos nas peças ao que ela respondeu: “É da cabeça mesmo. E a minha mãe pintava assim, né? Aí eu aprendi “quela”, estas coisas tudo aprendi com minha mãe e minha vó e minha tia” (INFORMAÇÃO VERBAL) 38 (figura 14).

\footnotetext{
${ }^{37}$ Conversa com Dona Pretinha dia 17out. 2014, em sua propriedade no Sítio Novo, rodovia TO 050.

${ }^{38}$ Conversa com Dona Andrelina 26 ago. 2014 em sua residência no Pé do Morro (zona rural de Arraias).
} 
Figura 15: Pintura das louças com argila colorida por Dona Pretinha, utilizando o pincel de buriti

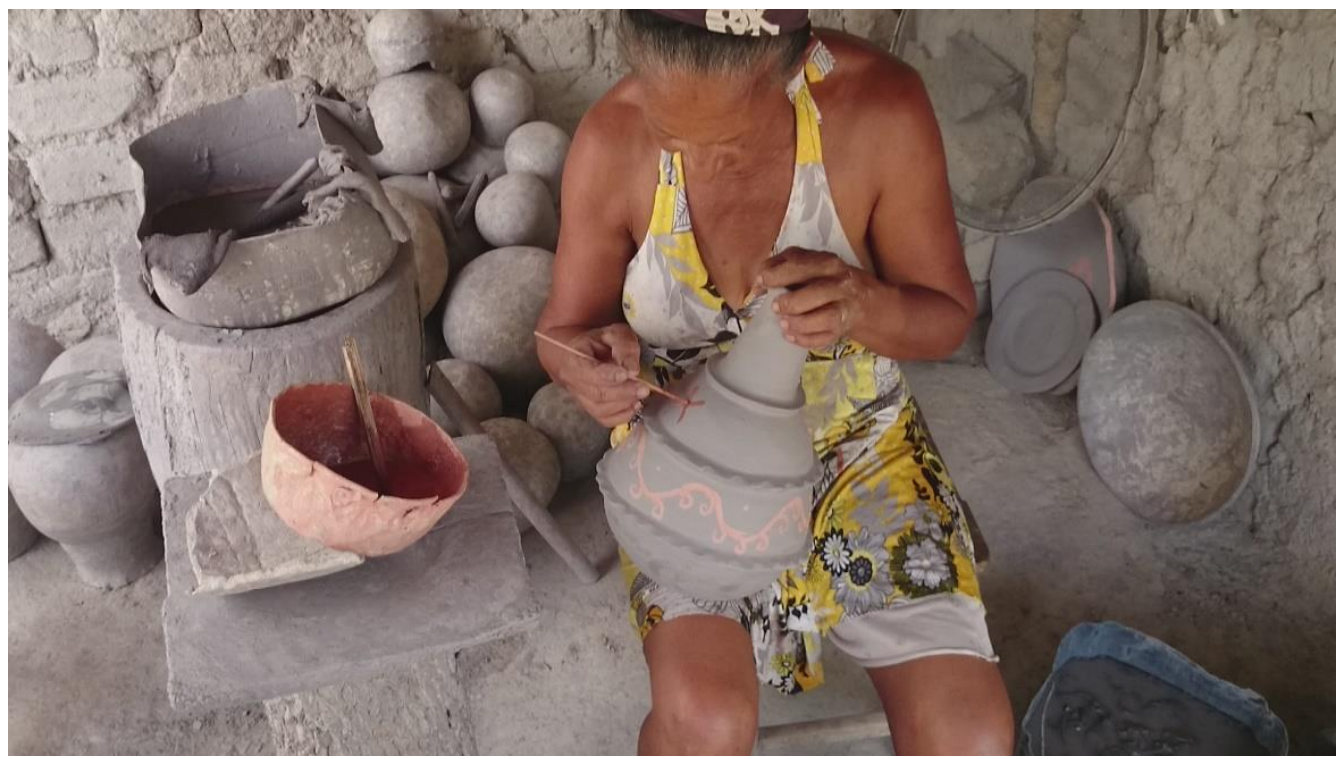

Fonte: Acervo da autora

Figura 16: Louças de Dona Andrelina pintadas aguardando o processo de queima

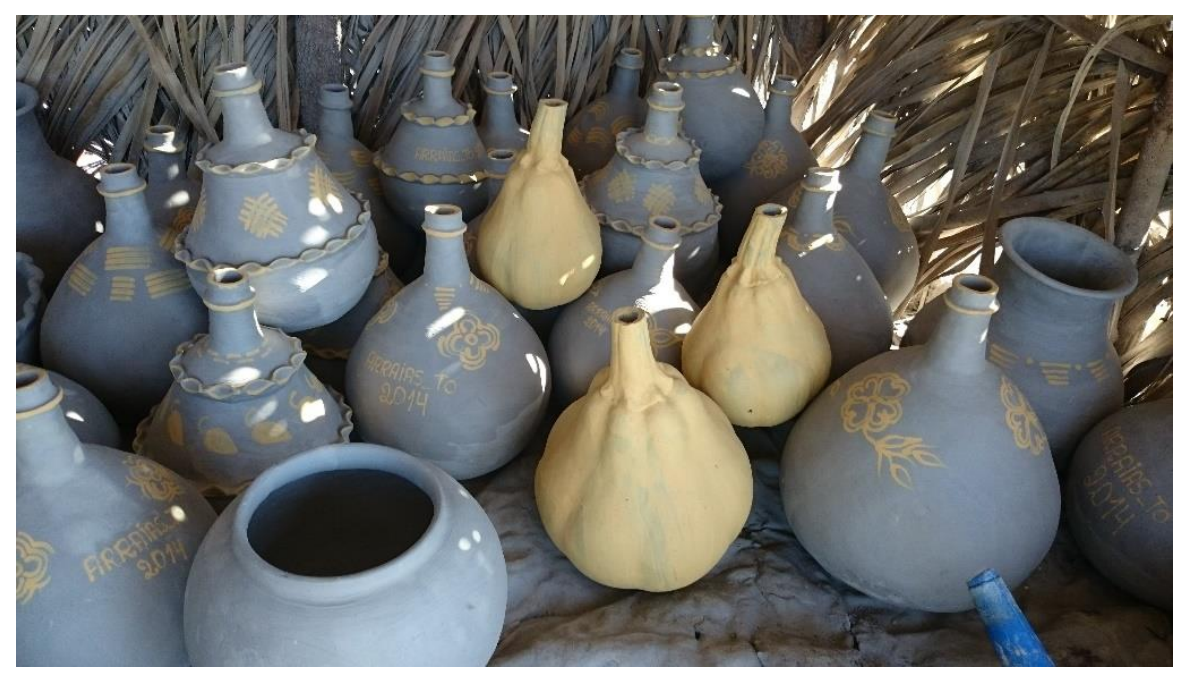

Fonte: Acervo da autora

Tanto Dona Andrelina como Dona Pretinha afirmam que o trabalho com as louças é cansativo, cada peça demanda um tempo enorme de dedicação e mesmo aplicando o conhecimento adquirido ao longo dos anos, existem problemas na execução do processo que podem causar prejuízos no preparo, como descrito por Dona Pretinha: "Perdi vazia ontem oh! 
Com aquela quentura, o vento rachou as bocas das vazia, portanto elas tá ali pra desmanchar de novo" (INFORMAÇÃO VERBAL) ${ }^{39}$.

Desenvolveram uma técnica apurada tanto no preparo das louças utilizando-se de várias formas geométricas, de analogias e de sistematizações como também nas pinturas com a argila colorida, onde o resultado é um conjunto de simetria estética, ou seja:

O método aqui não está ausente nem pode ser entendido como incipiente, precário, sem rigor. Trata-se, entretanto, de um método no plural e que caracteriza pela diversidade, destreza e criatividade de se ajustar às contingências dos materiais, fenômenos e função a que se destinam os produtos esperados (ALMEIDA, 2010, p. 118).

Os saberes da tradição envolvidos no desenvolvimento desta metodologia pertencem a outra matriz epistemológica distinta daquela que orienta o pensamento científico atual, como pontuado por Santos B., (2006, p. 152): "as perspectivas interculturais tem vindo a permitir o reconhecimento da existência de sistemas de saberes plurais, alternativos à ciência moderna ou que com esta se articulam em novas configurações de conhecimentos". Neste novo cenário em que se instala os saberes organizados e sistematizados de forma harmônica com os processos da natureza agregam elementos físicos e míticos, numa atitude de religação, característica marcante do pensamento complexo. Segundo Morin (2009a) a aprendizagem da religação deve se constituir como missão da reforma do pensamento paradigmática.

Almeida (2010) reforça ainda que a religação nestes termos estabelece uma vitalidade dos elementos simbólicos, naturais e míticos fortalecendo o elo entre o indivíduo e a natureza, criando uma relação simbiótica entre eles: "pode-se afirmar que não há lugar para a religião como um estatuto à parte nos espaços onde habitam o pensamento e os saberes da tradição" (ALMEIDA, 2010, p. 95).

No saber tradicional das mulheres do barro existem vários elementos que remetem a esta articulação de saberes, mesclando o conhecimento empírico sistematizado com o conhecimento mítico fortalecido por suas crenças. A época ideal para a retirada do barro é fruto dessa articulação de saberes:

Dona Pretinha estava trabalhando com o barro, confeccionando novas peças para aproveitar o restinho do barro, que segundo ela não foi tirado numa boa lua, então as louças racham ao serem feitas. Pergunto sobre a lua e ela me diz que o barro tem que ser retirado três dias antes da lua nova ou três dias depois, senão não serve para confeccionar as louças (não publicado) $)^{40}$.

\footnotetext{
${ }^{39}$ Conversa com Dona Pretinha dia 17 out. 2014, em sua propriedade no Sítio Novo, rodovia TO 050.

40 Anotações da autora em seu diário de campo em 29 jan. 2015.
} 
Em suas palavras: "Porque é assim oh! quando é na quadra da lua nova, num pode rancar o barro, estrala, racha no fazer" (informação verbal) ${ }^{41}$. Segundo (Lévi-Strauss, 1976, p. 31) "esta preocupação da observação exaustiva e do inventário sistemático das relações e das ligações pode levar, às vezes, a resultados de boa ordem científica [...]" como fica evidente nesse processo de retirada do barro para confecção das louças, pois quando Dona Pretinha trabalha com o barro que foi arrancado na fase da lua nova percebe a impossibilidade de produzir peças resistentes. Para o autor isso representa inclusive um processo de antecipação da ciência, pois: "a sistematização ao nível dos dados sensíveis, aos quais a ciência, durante muito tempo voltou as costas e que começa apenas a reintegrar na sua perspectiva" (1976, p. 32).

No caso da cerâmica o conhecimento matemático mistura-se a outros conhecimentos que envolvem a química e a física, isso torna-se evidente no manuseio do forno para a queima das peças, em que as peças são recobertas com cacos de cerâmica e após dezesseis horas de queima, aproximadamente, o fogo é retirado depois que se observa que os cacos estão na coloração branca, sinal de que as peças podem ser retiradas do forno. Segundo Pedreira et al. (2012) no processo de queima da cerâmica define-se a sua coloração, no caso de queima em fogueiras ao ar livre (queima oxidante) as peças ficarão com a coloração entre o amarelo-laranja e o marrom, e no caso da queima em fornos, chamada queima redutora, o resultado serão peças variando entre o branco e o negro. As louças de Dona Pretinha e de Dona Andrelina resultam do processo de queima redutora, por isso a coloração é branca.

O processo de queima das louças é iniciado após a confecção de uma quantidade grande de peças, dependendo das suas proporções, por volta de 100 a 150 peças, não existindo uma periodicidade definida para que tal processo ocorra. Elas são cuidadosamente colocadas no forno, onde as peças pequenas ocupam todos os espaços intermediários entre as peças maiores, os cacos das louças que foram rejeitadas são sobrepostos em cima dessa coleção e o fogo é aceso. Ele deve ser constante e permanecer durante um período de 14 a 16 horas aproximadamente, e ao ser apagado não pode restar nenhuma brasa acesa para que a louça não escureça: “Que eu tenho que levá o fogo devagazinho pra modi num istorá, num pode avexá o fogo que senão istora" (INFORMAÇÃO VERBAL) ${ }^{42}$.

A construção do forno de queima das louças também é uma técnica manual oriunda de conhecimento tradicional envolvendo as dimensões do forno, o barro para sua confecção e a colocação do crivo, uma espécie de grelha, segundo Dona Pretinha é a parte mais difícil da

\footnotetext{
${ }^{41}$ Conversa com Dona Pretinha 17out. 2014, em sua propriedade no Sítio Novo, rodovia TO 050.

${ }^{42}$ Idem, 2014.
} 
construção (figura 15). Dona Pretinha constrói seus fornos sozinha, Seu Messias não domina a técnica e no caso de Dona Andrelina ocorre ao contrário, Seu Pedro é o construtor dos fornos.

Figura 17: Forno para queima de louças fabricado por Dona Pretinha

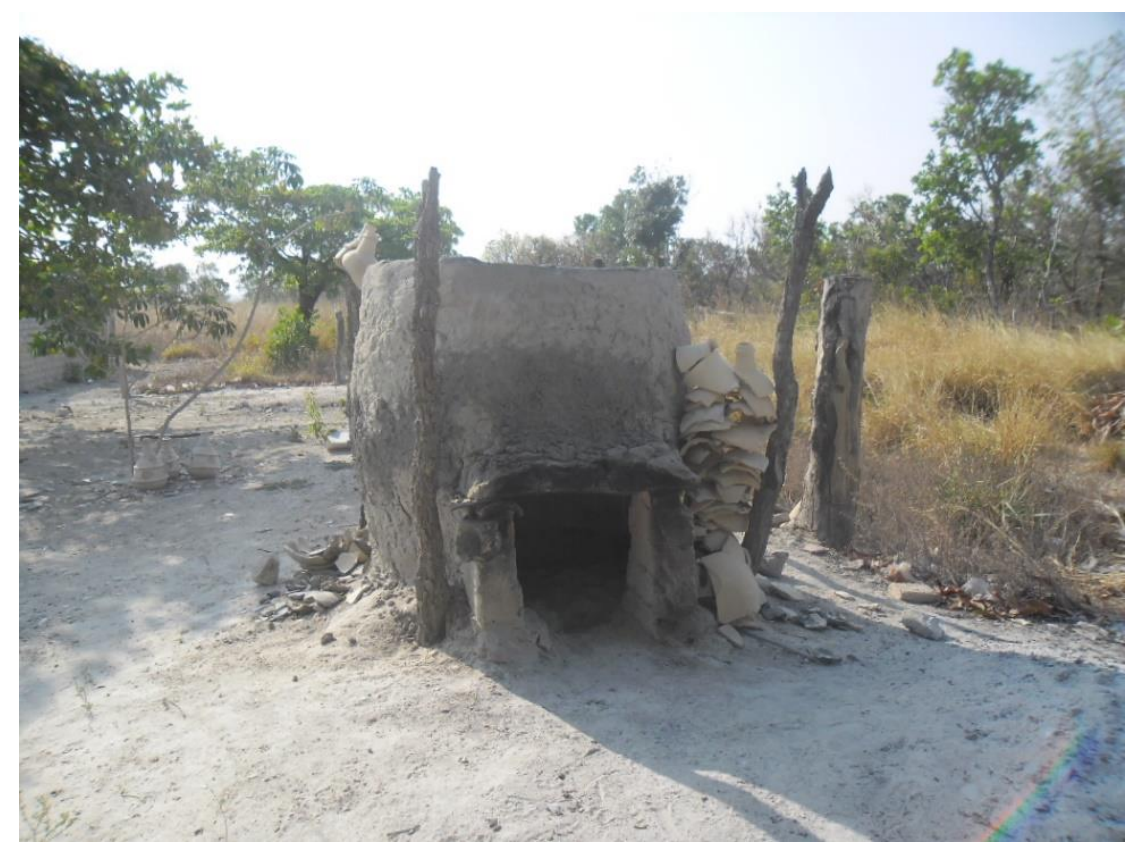

Fonte: Acervo da autora

Quando a louça está queimada, pronta é colocada numa prateleira de madeira bem próxima da estrada à espera dos compradores. Neste momento a visão que se tem ao se cruzar a estrada é da ordem da sensibilidade do olhar: "porque cremos que a visão se faz em nós pelo fora e, simultaneamente, se faz de nós para fora, olhar é, ao mesmo tempo, sair de si e trazer o mundo para dentro de si” (Chauí, 1988, p.33). O mundo que tocamos ao olhar as louças brancas, com seus desenhos simétricos, com suas marcas de dedos na forma de rendas envolvendo as peças, é o mundo da arte definido por Ostrower (1988, p. 177): "cada vez que se olha para uma forma expressiva, o próprio olhar encerra um momento de avaliação, de referência a si próprio, de referência a ritmos e tensões de espaços vividos e reencontrados na imagem. Tudo isso se passa no nível da intuição" (figura 16). 
Figura 18: Prateleira de madeira com as louças de Dona Pretinha na TO 050

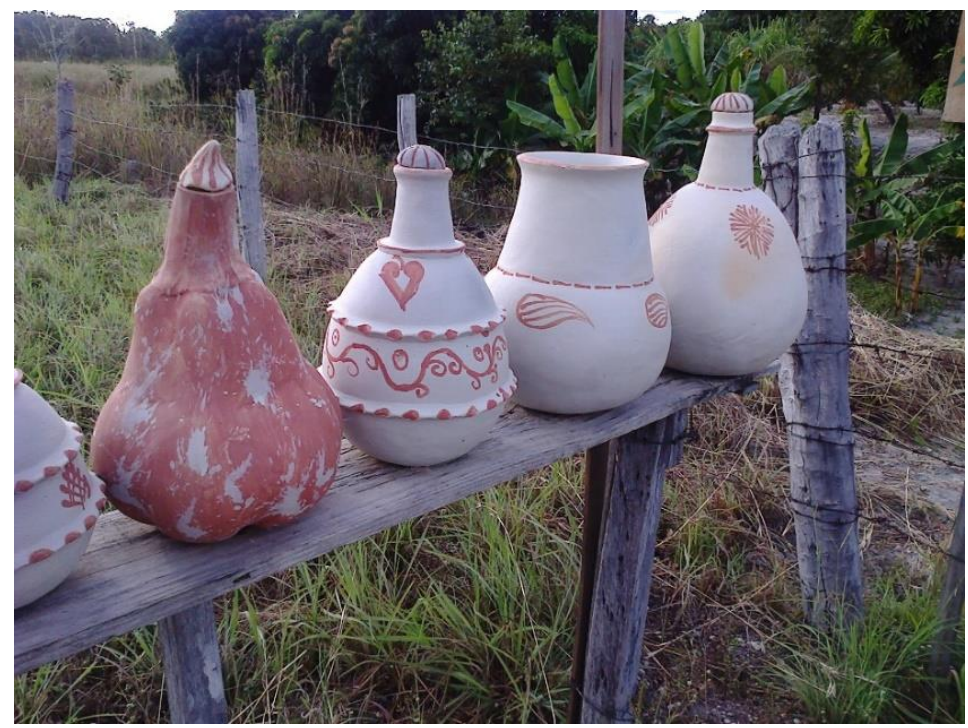

Fonte: Acervo da autora

Portanto, o processo de fabricação das louças de Dona Andrelina e de Dona Pretinha seguem as seguintes etapas: retirada da argila no barreiro, secagem, esmigalhamento sobre o couro curtido, peneiramento do barro, umedecer o barro, formação da chapa, modelagem da chapa sobre a forma, pré-secagem da peça ainda sobre a forma, retirada da forma, finalização da louça com alisamento de suas paredes, secagem, ornamentação com pintura de argila e queima da peça em forno apropriado.

\subsection{MATEMÁTICA DA SENSIBILIDADE}

O conviver com as mulheres artesãs do barro branco de Arraias me remete a um novo aprendizado matemático em que as proporções estabelecidas entre diferentes objetos cerâmicos ganham uma nova configuração, um novo senso de medida, identificado no método que Dona Andrelina utiliza para modelar as tampas das botijas: "É a mesma coisa, a gente enforma, vai medindo, assuntando para ver se dá, se não der tem que caçar outra, é desse jeito. É muito complicado a lida da gente! " (Informação verbal) ${ }^{43}$. Esta metodologia pode ser definida como baseada na sensibilidade, adquirida ao longo do tempo no processo contínuo de manuseio do barro: "diferentemente do senso comum, os saberes da tradição arquitetam compreensões com base em métodos sistemáticos, experiências controladas e sistematizações reorganizadas de

\footnotetext{
${ }^{43}$ Conversa com Dona Andrelina Ferreira Flores em 26 ago. 2014 em sua residência no Pé do Morro, zona rural de Arraias
} 
forma contínua" (Almeida, 2010, p. 67). Ao definir que o processo de medida das tampas nas bocas das louças é baseado no assuntar (definido como prestar atenção, observar, refletir ${ }^{44}$ ) das proporções entre as duas, Dona Andrelina estabelece a reflexão matemática embutida nesta sistematização, considerando que a escolha da tampa para uma determinada botija é uma comparação entre suas dimensões.

A produção das louças inicia sua sistematização matemática desde o momento da modelagem das peças, sendo que: "o modelo não é objeto, obra arquitetônica ou tecnologia, mas projeto, esquema, lei ou representação que permite a produção ou reprodução ou execução dessa ação" (Biembengut, 2004, p. 16), até a sua ornamentação. O modelo que as louceiras utilizam é derivado de uma lógica interna, à medida que vão trabalhando a peça com as mãos elas estabelecem as medidas da espessura das paredes da louça a ser fabricada.

Após a modelagem que define o formato e as dimensões da peça que será produzida, as artesãs durante a etapa de alisamento da peça determinam as proporções almejadas e por meio da observação contínua detectam quais sãos os erros que precisam ser corrigidos. A correção é feita no momento de acrescentar os pescoços das botijas ou na finalização das panelas e dos potes. Como pontuado por Morin (2011, p.72): "é certo que todos os conceitos científicos extraídos da experiência social se emanciparam e transformaram. Nem por isso se separaram totalmente: força, trabalho, energia, ordem, desordem conservam seu cordão umbilical com a vida comum".

E a vida comum das artesãs do barro conhece de maneira intrínseca todas as propriedades da argila, de forma que: "conhecimento, criatividade e consciência são três termos conexos - e, no limite tautológicos - que exprimem a matriz da interdependência constantemente renovável entre a pessoa, a coisa e o seu significado" (VERGANI, 2009, p. 253).

As louças são secadas ao ar livre e então inicia-se o processo de ornamentação com a argila colorida captada das barrancas dos rios e córregos. Neste processo de ornamentação o conceito matemático de simetria desempenha papel relevante no desenvolvimento artístico da obra: "simetria não é um número nem um formato, é um tipo especial de transformação - uma maneira de mover um objeto. Se o objeto parecer o mesmo depois de movido, a transformação aí presente é uma simetria" (STEWART, 2012, p.9).

A simetria é um processo que mantém uma forma invariante por meio de operadores simétricos ou operações de simetria. Ela pode manter inalterada a forma ou as distâncias entre

\footnotetext{
${ }^{44}$ Dicionário Houaiss. Disponível em <http://houaiss.uol.com.br/busca?palavra=assuntar>. Acesso em 26 set. 2015.
} 
elas, ou ambas. A simetria estabelece uma determinada relação entre as partes e o todo, sendo muitas vezes imputada como a responsável pela beleza estética, ou seja: "a simetria é um conceito importante na filosofia da arte e na estética porque ela é um dos fatores determinantes da emoção estética, quando se trata de superfícies ou sólidos tidos e reputados como belos" (ROHDE, 1982, p. 175).

O conceito de simetria é milenar usado desde os tempos primitivos, registrado em pinturas de cavernas pré-históricas datadas de 20 mil a 25 mil anos, onde é possível perceber "a coerência das formas e o senso das proporções" (Ostrower, 1988, p.168). A simetria percorreu o pensamento filosófico da Grécia Antiga manifestando seus conceitos nas obras arquitetônicas e artísticas do período greco-romano, segundo Rohde (1982, p. 46) o médico grego Claúdio Galeno (130-200) dizia “que a beleza consta da simetria das partes, na proporção de um dedo em relação ao outro, de todos os dedos em relação à mão...em conclusão, de todas as partes em relação às demais".

As operações de simetria são definidas a partir da reprodução de um motivo ou módulo, sendo este a menor das partes que se repete na operação (figura 17). As operações podem ser classificadas em translação, rotação e reflexão, dependendo do tipo de transformação que o módulo sofre em seu movimento (Rohde, 1982). No estudo das operações de simetria são necessários conceitos matemáticos, como as transformações lineares que não serão tratados neste texto.

Figura 19: Motivo ou módulo de um ornamento matemático

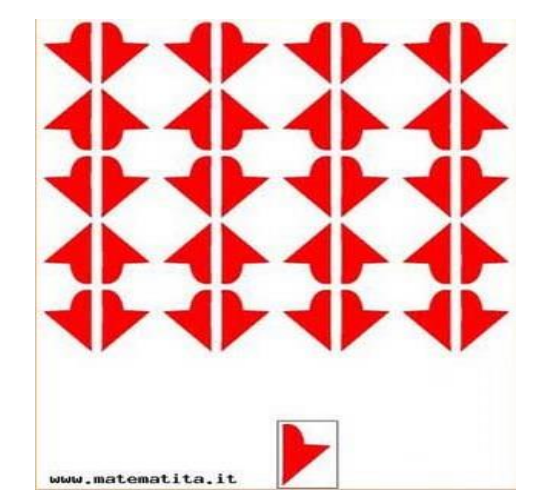

Fonte: Site de busca na internet ${ }^{45}$

\footnotetext{
${ }^{45}$ Disponível em

$<$ https://www.google.com.br/search?q=ornamentos+matematicos\&espv=2\&biw=1366\&bih=667\&source=lnms \&tbm=isch\&sa=X\&ved=0ahUKEwitsYSQyc_KAhWDiZAKHSODBp4Q_AUIBigB\#tbm $=\mathrm{isch} \& q=$ simetria $++\mathrm{d}$ e+transla\%C3\%A7\%C3\%A3o\&imgrc=toxL99Qez8XnoM\%3A>. Acesso em 19 out. 2015.
} 
A translação (figura 18) é uma operação simples em que o módulo se repete sobre uma curva, periodicamente, e a distância entre os pontos e a forma do motivo mantém-se inalterados.

Figura 20: Simetria de translação

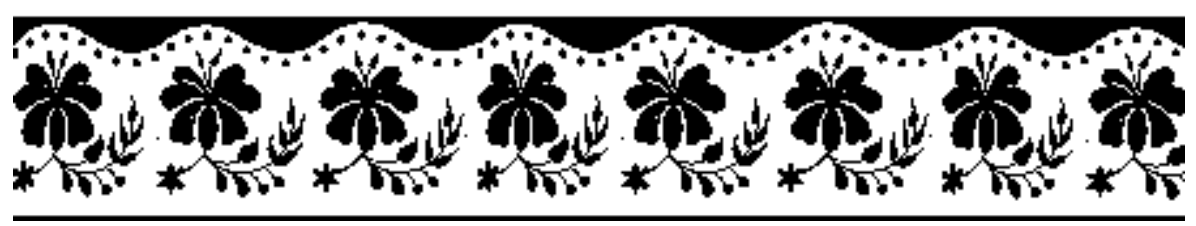

Fonte: Site de busca na internet ${ }^{46}$

A rotação (figura 19) também é uma operação simétrica simples, chamada de simetria cíclica ou rotatória, o módulo após percorrer uma volta completa em torno de um eixo retoma sua posição no espaço. Esta simetria pode ser encontrada em muitas construções arquitetônicas como castelos medievais, a Torre Eiffel e a Torre de Pisa (ROHDE, 1982).

Figura 21: Simetria de Rotação

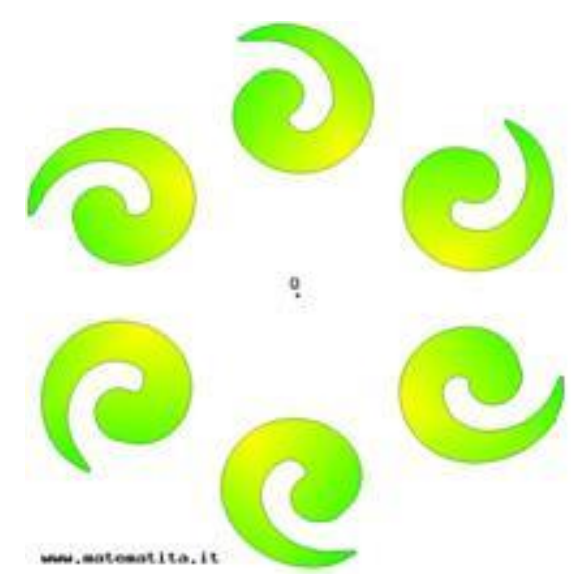

Fonte: Site de busca na internet ${ }^{47}$

\footnotetext{
${ }^{46}$ Disponível em

$<$ https://www.google.com.br/search?q=ornamentos+matematicos\&espv=2\&biw=1366\&bih=667\&source=lnms \&tbm=isch\&sa=X\&ved=0ahUKEwitsYSQyc_KAhWDiZAKHSODBp4Q_AUIBigB\#tbm=isch\&q=simetria++d e+transla\%C3\%A7\%C3\%A3o\&imgrc=toxL99Qez8XnoM\%3A>. Acesso em 19 out. 2015.

${ }^{47}$ Disponível

em: $<$ https://www.google.com.br/search?q=ornamentos+matematicos\&espv=2\&biw=1366\&bih=667\&source=ln ms\&tbm=isch\&sa=X\&ved=0ahUKEwitsYSQyc_KAhWDiZAKHSODBp4Q_AUIBigB\#tbm=isch\&q=simetria+ +de+rota\%C3\%A7\%C3\%A3o\&imgrc=piXmfvk7DE-0LM\%3A>. Acesso em 19 out. 2015.
} 
A simetria da reflexão (figura 20) é chamada de bilateral por duplicar a imagem do módulo como se ele estivesse diante do espelho, sendo composta por um eixo imaginário que divide as duas formas.

Figura 22: Simetria de reflexão

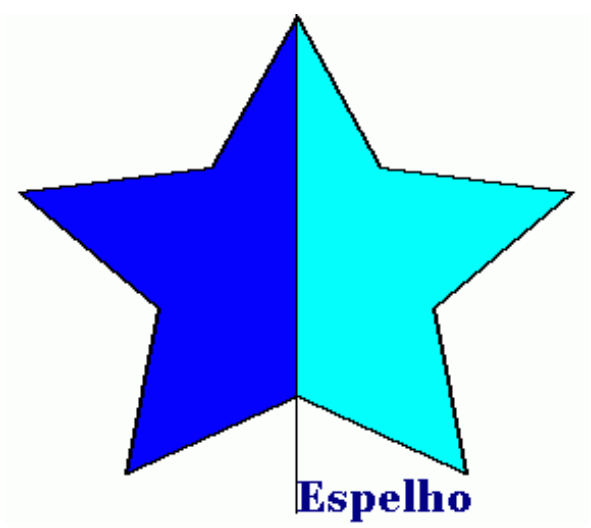

Fonte: Site de busca da internet ${ }^{48}$

A beleza estética presente nas operações de simetria não é apenas fruto da construção humana em obras da arquitetura e das artes plásticas, a simetria apresenta-se na constituição dos organismos vivos desde a formação das células até a estrutura dos animais. A simetria está presente no corpo humano, nas plantas, nos frutos, nas flores, na constituição dos cristais, na forma das galáxias. Enfim, a simetria orienta a relação de harmonia e equilíbrio das formas físicas constituindo padrões regulares que podem ser repetidos.

Os ornamentos matemáticos são compostos por meio das operações simétricas descritas: translação, rotação e reflexão, podendo também resultar da composição de várias dessas operações combinadas. Basicamente existem três tipos de ornamentos: as barras decorativas em que o motivo se repete num determinado movimento entre duas linhas paralelas, as rosetas onde a repetição do módulo acontece numa determinada área do plano e os mosaicos em que o tema se repete cobrindo toda a área do plano (BASSANEZI; FARIA, 1988).

As louças de Dona Andrelina e de Dona Pretinha possuem padrões de simetria em suas ornamentações. Estes movimentos produzem a harmonia do conjunto e expressam a sensibilidade do artista na organização espacial de sua obra, denotando o que Faya Ostrower (1988, p.170) define como essencial numa obra de arte, "consciente ou inconscientemente, há sempre um depoimento sobre o sentido de viver". Os motivos que ornamentam as louças de

\footnotetext{
${ }^{48}$ Disponível em $<$ https://www.google.com.br/search?q=ornamentos+matematicos\&espv=2\&biw=1366\&bih=667\&source=lnms $\&$ tbm=isch\&sa=X\&ved=0ahUKEwitsYSQyc_KAhWDiZAKHSODBp4Q_AUIBigB\#tbm=isch\&q=simetria++ matematica\&imgrc=o8oll1iJDw392M\%3A>. Acesso em 19 out. 2015.
} 
Dona Pretinha e Dona Andrelina são figuras geométricas estilizadas, como triângulos, círculos, quadrados, flores, galhos de flores, trançados e a sua simetria é estabelecida pelos movimentos do tema. A maioria das louças apresenta a ornamentação de barras decorativas (figuras 21 e 22) e as linhas paralelas são compostas pelas franjas de barro marcadas pelos seus dedos que imitam a leveza de uma renda. Existem louças com ornamento do tipo mosaico que são as abóboras (figura 23), botijas que imitam o formato de uma abóbora, inclusive nos detalhes dos talos e também as louças pintadas com ornamentos do tipo roseta, em que o desenho ocupa uma pequena superfície do plano (figura 24).

Figura 23: Louça de Dona Andrelina com tema se repetindo entre duas linhas paralelas (faixa decorativa)

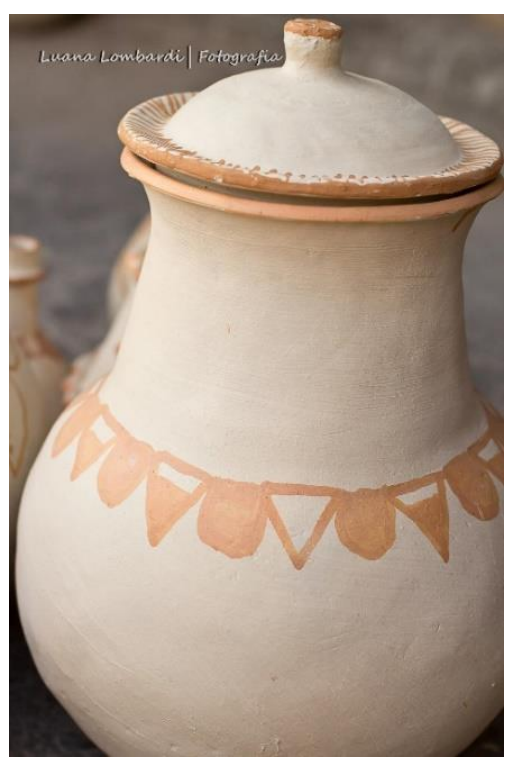

Fonte: Acervo particular Luana Lombardi 
Figura 24: Botija de Dona Andrelina com ornamento de faixa decorativa

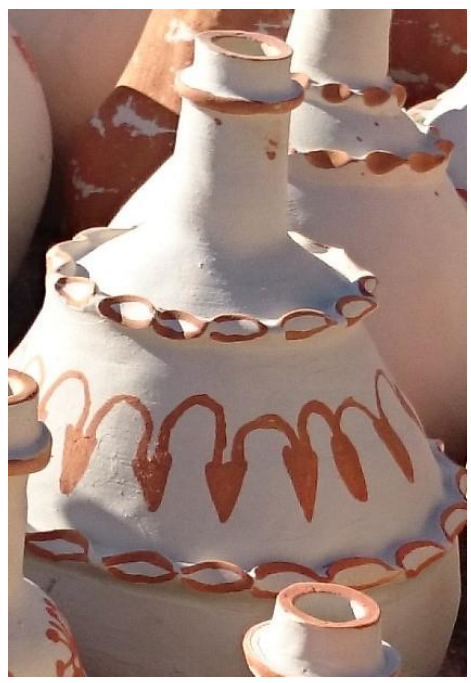

Fonte: Acervo da autora

Figura 25: Botija no formato de abóbora com ornamento do tipo mosaico

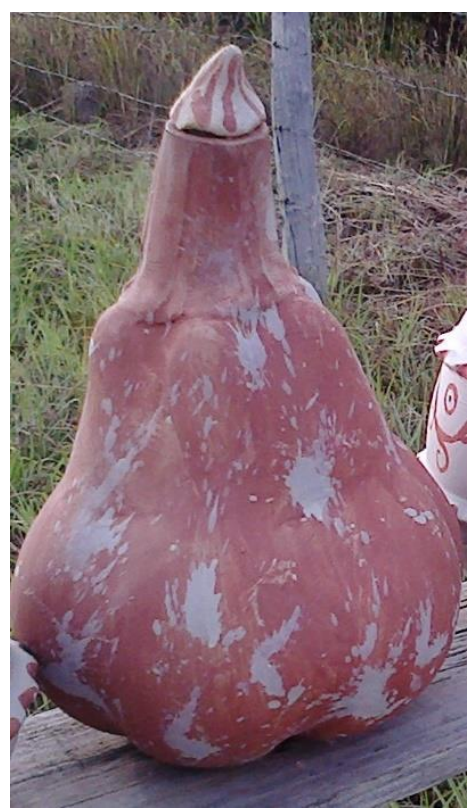

Fonte: Acervo da autora 
Figura 26: Botija com ornamento do tipo roseta

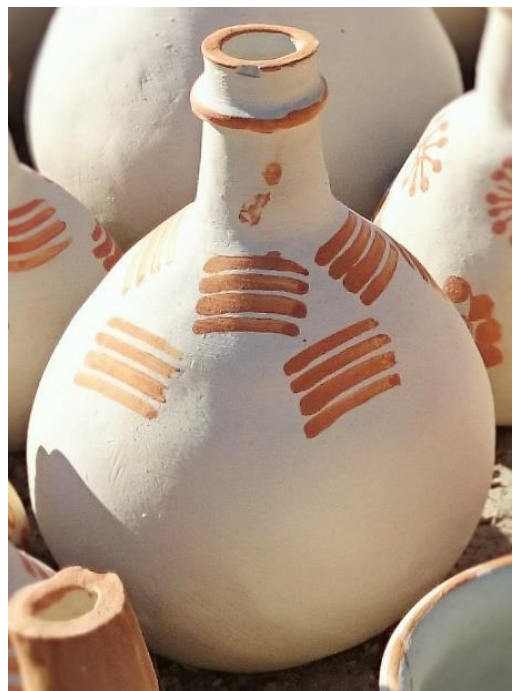

Fonte: Acervo da autora

\subsection{MITOLOGIA DAS MULHERES DO BARRO}

Dona Andrelina e Dona Pretinha são cunhadas, as únicas louceiras herdeiras da tradição do barro no município de Arraias, vivendo uma relação de animosidade que lembra em alguns momentos os mitos envolvendo a oleira ciumenta descritos por Lévi-Strauss (1985, p. 46) "Tudo isso mostra que os mitos e crenças estabelecem uma ligação entre a cerâmica e o ciúme". Elas desmerecem o trabalho uma da outra, como dito por Dona Andrelina: "Aí ela fala assim: ela num sabe fazer não, ela faz torta de lama e me atrapaia até! Num é pra mim vender nada, num é pra fazer nada!" (informação verbal) ${ }^{49}$ sendo que Dona Pretinha também reclama do artesanato de sua concorrente, afirmando que seus potes racham e são feios e quem compra dela acaba se arrependendo ao comparar com a beleza das suas peças.

No universo mítico de Dona Andrelina e de Dona Pretinha existem forças as quais elas denominam de mau olhado que é suficiente para desandar as louças, quebrá-las, torná-las impróprias para a comercialização. O mau olhado está depositado no outro, ou melhor dizendo na outra, “[...] olho poderoso. Capaz de despir, devorar, matar. Não é o olhar alheio fonte de alienação? Não me transforma em coisa, indagava Sartre? Não me aniquila, roubando-me a condição de sujeito? Não é por ele que o 'inferno são os outros'?" (Chauí, 1988, p. 33). Este olhar que racha as louças, baseado no ciúme pode até mesmo causar as doenças, as doenças das pernas provocadas pelas varizes, as dores que não cessam com remédio de farmácia levando ao

\footnotetext{
${ }^{49}$ Conversa com Dona Andrelina em 26 ago. 2014 em sua residência no Pé do Morro (zona rural de Arraias).
} 
padecimento constante, mesmo que elas não se vejam, não se olhem, o mau existe e permanece presente neste universo.

Dona Pretinha e Dona Dona resistem, cada uma em sua labuta, com suas defesas, porém completamente hostis entre si. Não se falam, mas comentam o trabalho uma da outra, desmerecendo-o, consideram-se rivais, absortas num universo de mitos e simbologia, onde pequenos gestos são suficientes para definir suas atitudes, conforme Lévi-Strauss (1976, p. 43):

Por sua parte, o pensamento mítico não é somente o prisioneiro de acontecimentos e de experiências, que ordena e reordena, incansavelmente, para lhes descobrir um sentido; é também libertador, pelo protesto feito contra a falta de sentido, com que a ciência estava, a princípio, resignada a transigir.

Para Morin (1999, p. 176): “ o universo mitológico é um emissor de mensagens e toda coisa natural é portadora de símbolos. Nesse sentido, o pensamento mitológico caracteriza-se por uma proliferação semântica e um excesso de significações”, em suas conversas as duas artesãs ao se referirem à rival, mudam o semblante, não pronunciam o nome da concorrente: "o Nome dispõe do poder de evocar a coisa nomeada; a Palavra mágica chama e ordena” (1999, p. 181), utilizam-se de símbolos como referência ao trabalho da outra: “É, só nós duas, as únicas louceiras, aquela dali da curva do S! " (Informação verbal) ${ }^{50}$. Não foi possível detectar em que momento de suas vidas aconteceu esta ruptura de relações considerando o parentesco existente entre elas que poderia ser motivo de aproximação, inclusive por causa da atividade profissional que marca suas vidas de maneira tão intensa. Porém, não existe possibilidade de estabelecer nenhuma relação de proximidade, ao contrário o sentimento recíproco é de desprezo e de repulsa.

As duas artesãs não aceitam que suas louças ocupem o mesmo espaço, qualquer tentativa, mesmo restrita as suas peças artesanais é motivo de desconfiança, como se a proximidade pudesse estabelecer algum tipo de ponte, elo entre elas. Elas reconhecem esteticamente o trabalho uma da outra e são capazes inclusive de perceber as diferenças no volume das peças e no traçado dos desenhos, mesmo em fotos. Dona Andrelina recorda que elas trabalharam juntas em um mesmo projeto organizado pelo Sebrae, tempos atrás. O projeto objetivava ensinar o artesanato nas escolas públicas do município e as artesãs também confeccionavam peças para serem vendidas na capital recebendo quinzenalmente pelo trabalho. Foi um período, talvez o único, em que elas compartilharam o mesmo ambiente.

\footnotetext{
${ }^{50}$ Conversa com Dona Andrelina em 26 ago. 2014 em sua residência no Pé do Morro (zona rural de Arraias).
} 
Elas afirmam que o barro não pode ser retirado de locais aonde existe a criação de gado, segundo suas crenças a urina do gado, cheia de sal contamina o barro, prejudicando suas propriedades: "Por que dá o sal pro gado, né? O gado faz o xixi, aí o barro tem xixi, tem sal, né? ${ }^{51 ”}$ (Informação verbal), o que é confirmado por pesquisas científicas segundo Silva, R. (2015): "na urina tem muito sódio $(\mathrm{Na}+)$, esse cátion monovalente pode saturar as cargas negativas da argila e promover a dispersão química do solo, o que é o inverso do que elas precisam [...]". Elas se acusam mutuamente de que os barreiros próximos a suas propriedades foram infectados propositalmente por sua rival, com a intenção clara de impedir a retirada do barro para a confecção das peças.

Por isso, Lévi-Strauss (1976) afirma que a tese vulgar de que a magia "seria uma modalidade tímida e balbuciante da ciência" (p. 33) não tem fundamento, pois o pensamento mágico forma "[...]um sistema bem articulado, independente, neste ponto, desse outro sistema que constituirá a ciência, exceto quanto à analogia formal que os aproxima e que faz do primeiro uma espécie de expressão metafórica do segundo" (p. 34). A ciência e a magia podem ser colocadas em paralelo como duas formas distintas do conhecimento, diferenciando-se em relação aos resultados práticos e teóricos obtidos, porém comungando do mesmo nível de operações mentais que desencadeiam.

Neste universo carregado de forças negativas desencadeadas por sua rivalidade, Dona Pretinha e Dona Andrelina comungam do mesmo simbolismo inerente aos seus saberes tradicionais, utilizando-se de elementos próprios ao que Morin (2011, p. 141) define como noosfera:

As representações, símbolos, mitos, ideias são englobados, ao mesmo tempo, pelas noções de cultura e de noosfera. Do ponto de vista da cultura, constituem a sua memória, os seus saberes, os seus programas, as suas crenças, os seus valores, as suas normas. Do ponto de vista da noosfera, são entidades feitas de substância espiritual e dotadas de certa existência.

\subsection{ECOLOGIA DE SABERES: O DIÁLOGO ENTRE A FORMA E O OLHAR}

A Ecologia de Saberes objetiva abrir as portas do reconhecimento científico aos saberes que foram desprezados e esquecidos por não compartilhar a mesma fonte epistemológica à qual

\footnotetext{
${ }^{51}$ Conversa com Dona Andrelina em 26 ago. 2014 em sua residência no Pé do Morro (zona rural de Arraias).
} 
a ciência pertence. Este reconhecimento insere-se na categoria do diálogo, pois somente através da busca de pontos comuns é possível estender pontes entre diferentes conhecimentos, como afirma Santos B. (2006, p. 161): “A ecologia de saberes exerce-se pela busca de convergências entre conhecimentos múltiplos". A ciência moderna assentada no paradigma da fragmentação e da especialização características da monocultura do pensamento defronta-se com a ecologia de saberes baseada no interconhecimento, na simbiose de saberes que se intercruzam e se interconectam, reforçando a emergência de um novo paradigma, "hoje, a mudança de paradigma na ciência, em seu nível mais profundo, implica uma mudança da física para as ciências da vida" (CAPRA, 2006, p. 29).

Na realização da pesquisa e do registro etnográfico das louceiras de Arraias é possível distinguir a pluralidade de conhecimentos que esta prática produz, desde a retirada do barro, a sua preparação, a confecção das louças, sua ornamentação e por fim a queima das peças. Vários saberes estão envolvidos neste fazer, mesmo que as artesãs acostumadas com sua lida e na maioria das vezes sofrendo a injustiça cognitiva própria de sua condição social não percebam o quanto o seu conhecimento possui de valor científico, além do patrimônio artístico que seu artesanato revela.

Permitir que estes saberes adentrem a universidade representa a possibilidade de seu resgate enquanto conhecimento tradicional não permitindo que fiquem silenciados nas vozes dessas duas mulheres artesãs, como pontuado por Almeida (2010, p. 120): “a fertilidade desse diálogo requer, entretanto, que não se reduza um saber ao outro, que não se valide um por critérios estipulados pelo outro, uma vez que tratam de estratégias distintas de pensar o mundo". Este conhecimento construído ao longo dos anos pela sistematização do trabalho artesanal dessas duas senhoras ainda não adentrou a universidade, encontra-se em processo de estabelecimento de diálogo. Um diálogo a ser construído nas bases do que Edgar Morin argumenta como fundamental, a aprendizagem da religação: "acrescento que a religação constitui de agora em diante uma tarefa vital, porque se funda na possibilidade de regenerar a cultura pela religação de duas culturas separadas, a da ciência e a das humanidades" (MORIN, 2009, p. 70).

Os saberes das artesãs estão inseridos na matriz etnomatemática, apresentando analogias e sínteses próprias do pensamento matemático, porém tais características não são facilmente decodificadas pela matemática formal, é preciso uma reforma do pensamento para consentir este diálogo, considerando o que Vergani (2009, p.235) aponta como objetivo da Etnomatemática: "a Etnomatemática partilha esta alternância rítmica de manifestações humanas, e abre-se tanto às energias subterrâneas do desejo como ao rigor do pensamento 
estruturante". Tais saberes desenvolvem-se por meio de um pensamento simbólico onde as sistematizações são processadas analogicamente de forma a garantir a simetria estética de sua obra: "a exploração analógica conduz, assim, a perspectivas holísticas cuja harmonia é um elemento essencial da beleza das matemáticas" (2009, p.137). O pensamento simbólico/matemático que permeia o processo de desenvolvimento do artesanato do barro caracteriza-se pelo que Gerdes (2012) descreve como pensamento geométrico presente em técnicas de entrelaçamento geométrico utilizado em cestarias, tecelagem, construção de jangadas e de abrigos como também na olaria tanto de antigas civilizações como em comunidades tradicionais da atualidade:

\footnotetext{
O entrelaçamento em espiral reflete-se na técnica mais recente da olaria mais antiga, onde o barro é primeiro moldado na forma de varas redondas que depois são enroladas umas contra as outras em espiral. Mais tarde, ajusta-se a forma, mas ela permanece com a simetria de rotação. A origem da simetria das panelas assim produzidas reside na imitação da técnica do cordão espiralado. (GERDES, 2012, p. 85)
}

A técnica do entrelaçamento em espiral é utilizada pelas louceiras de Arraias no processo de finalização de suas peças, a partir do momento em que a peça é retirada do molde após a pré-secagem, além disso o pensamento geométrico apresenta-se de maneira inerente à simetria dos desenhos dispostos em suas louças.

Este conhecimento transformado em arte geométrica por suas mãos calejadas não é facilmente transmissível para a linguagem formal da matemática, necessita de um processo codificador que pode ser relacionado com o que Alangui apud Miarka (2013) aborda como essenciais ao pesquisador etnomatemático: o diálogo entre a prática cultural e a matemática e o paralelo entre as duas práticas usando elementos de um sistema para questionar ao outro. Dessa forma, segundo o autor seria possível estabelecer o diálogo entre os dois saberes, num processo denominado por ele de 'interrogação mútua'.

Observo o quanto esta proposta de interrogação mútua estabelece convergências com a justiça cognitiva apontada pela Ecologia de Saberes, afinal por meio desse espaço epistêmico de diálogo entre a matemática formal, institucionalizada e a matemática espontânea das louceiras de Arraias é possível quebrar o paradigma vigente que concebe a cultura científica como superior a outros saberes. Porém a questão que se coloca é como promover este espaço epistêmico? Quais são as possibilidades de promover a interrogação mútua entre saberes distintos? 
O campus da UFT/Arraias deve ser o espaço deste resgate epistemológico representando para a UFT a possibilidade de reassumir sua postura de universidade comprometida com a reforma de pensamento, no sentido apontado por Buarque (1994, p. 157):

\begin{abstract}
A universidade será esquina dos saberes, o instrumento de convergência do saber existente na sociedade. Ela receberá saber criado em todas as partes, por todas as pessoas, e servirá como elemento de intercâmbio. Acabará o monopólio de apenas alguns transmitirem o saber a outros. Alguém sempre terá a quem ensinar algo.
\end{abstract}

Considerando que as raízes da UFT foram fincadas na universidade de ideias como registrado pelo Prof. Alan Barbiero, primeiro reitor da instituição: "houve uma reunião em que levei o texto do Boaventura, que está no livro 'Pela mão de Alice', aquele que trata a 'Ideia de Universidade ou a Universidade de Ideias' e discutimos bastante sobre o que queríamos para a UFT'(informação verbal) ${ }^{52}$, e que suas origens baseiam-se no paradigma da reforma do pensamento, como testemunham os momentos simbólicos que a instituição viveu no Seminário Internacional "Distintos Olhares" de 2009 e na Avaliação Internacional promovida pela ORUS, é oportuno estabelecer condições para que a universidade possa transformar o conhecimento universitário em conhecimento pluriversitário desenvolvendo: "[...] um conhecimento transdisciplinar que, pela sua própria contextualização, obriga a um diálogo ou confronto com outros tipos de conhecimento" (Santos, B., p. 30), tendo em vista que apesar da importância destes momentos não houve nenhum desenvolvimento posterior destas ações na UFT.

Esta universidade que participou como co-autora do Manifesto Tocantins (2009) onde se afirmou que: "precisamos estar abertos para identificar e dialogar com os distintos olhares que busquem uma definição de novas vias, pautadas pela solidariedade e fraternidade"(Ward, 2015) necessita definir caminhos para tornar realidade esta proposta apontada no Seminário Internacional.

Além de todas estas razões, o campus da UFT de Arraias insere-se num contexto histórico, social e mítico que aponta para a convergência dos saberes tradicionais e científicos, permitindo que a Etnomatemática com suas características epistemológicas próprias desencadeie esta religação de saberes, por meio da revolução epistemológica da Ecologia de Saberes, considerando que: "a primeira característica híbrida da etnomatemática a levar em conta é o seu empenho no diálogo entre identidade (mundial) e alteridade (local), terreno onde a matemática e a antropologia se intersectam" (VERGANI, 2007, p. 14).

\footnotetext{
${ }^{52}$ Conhecimento adquirido por meio de entrevista com o Prof. Alan Barbiero em 29 nov.2013 na Secretaria Estadual de Meio Ambiente em Palmas, Tocantins.
} 
No livro "As novas dimensões da universidade" resultante da oficina de Avaliação Internacional desenvolvida pela ORUS na UFT, Frate, Vicentim e Chalub Martins (2012, p.130) descrevem uma prática comum desenvolvida pela Universidade de Brasília (UnB) e pela Universidade Federal da Paraíba (UFPB) o envolvimento em seus projetos de extensão de voluntários e de auxiliares que são denominados de extensionistas colaboradores, além dos docentes e discentes da universidade. Neste sentido a proposta que apresento é de que as louceiras de Arraias sejam inseridas no campus da UFT/Arraias como extensionistas colaboradoras, no formato concebido pela UnB em sua implantação no ano de 2006 (resolução em Anexo ) participando de forma ativa da elaboração e implantação de projetos que tenham como bússola a Ecologia de Saberes e como mapa de localização as contribuições da Etnomatemática à matemática acadêmica.

A inserção social desencadeada por este tipo de ação torna realidade a universidade como esquina de saberes, proposta por Buarque (1994), promovendo a reforma do pensamento na perspectiva descrita por Morin $(2003$, 2009), como também apresenta a prática da Ecologia de Saberes como "uma epistemologia construtivista e realista" (Santos, B., 2006, p. 158).

A proposta de tornar as louceiras de Arraias extensionistas colaboradoras na universidade é suficiente para retirar da situação de risco de extinção os seus saberes e fazeres? Como promover um contato respeitoso e solidário entre seus saberes tradicionais que são executados em ambientes simples e naturais com o ambiente solene da universidade? A sistematização de fabricação das louças baseada na bricolagem (bricoleur) onde o processo vai sendo construído à medida que se fabrica as peças, numa relação intensa entre as características da argila, a sensibilidade da artesã, seus mitos enfim toda sua história inscrita nas botijas, gamelas e potes, pode se tornar um conhecimento matemático apropriado pela universidade? Quais são as possibilidades dessa apropriação?

Teresa Vergani (1991) apud Carlos Farias e Mendes (2014) considera existir uma rede intrincada entre matemática, sociedade, cognição e cultura, e que por meio de exercícios de cultura matemática é possível explorar didaticamente práticas socioculturais para uma educação matemática plural.

É nessa interação transversalizante, na qual a matemática está inserida como uma forma de olhar a natureza, a sociedade e a cultura, que argumentamos favoravelmente acerca da investigação e problematização das práticas socioculturais como um caminho plural na aprendizagem da matemática escolar (FARIAS, C.; MENDES, 2014, p.44). 
Na busca da interrogação mútua (Miarka, 2013) entre seus saberes e a matemática formal, abrir as portas da universidade através da Ecologia de Saberes para as louceiras de Arraias significa quebrar o paradigma da disjunção e da separação para a instauração da transdisciplinaridade como território: "a transdisciplinaridade repousa sobre uma atitude aberta, de respeito mútuo e mesmo humildade, com relação a mitos, religiões e sistemas de explicações e conhecimentos, rejeitando qualquer tipo de arrogância e prepotência (D'AMBROSIO, 2012) 


\section{CONSTRUINDO PONTES ENTRE A MATEMÁTICA SENSÍVEL DO BARRO E} A MATEMÁTICA ACADÊMICA

Figura 27: Produção de potes e botijas de Dona Andrelina em setembro de 2014

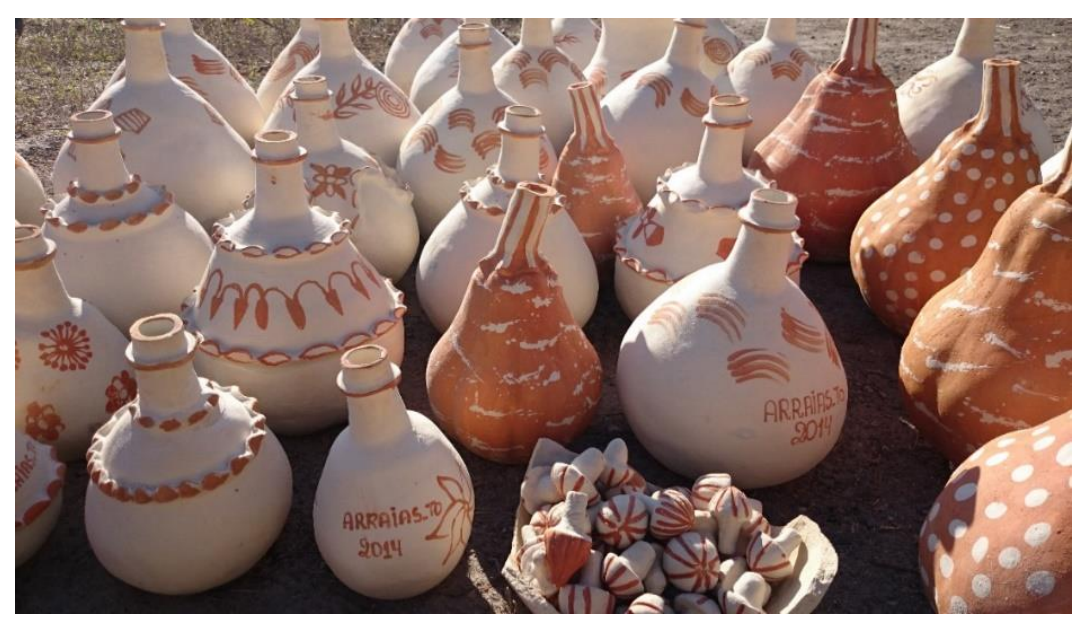

Fonte: Acervo da autora 


\subsection{SOBRE AS PONTES}

A proposta de estabelecer pontos de contato, ou pontes, entre a matemática da sensibilidade das louceiras de Arraias e a matemática acadêmica do curso de Licenciatura em Matemática do campus de Arraias da UFT parte do pressuposto apontado por Carlos Aldemir Farias e Iran Abreu Mendes (2014):

É, portanto, no exercício de reinvenções da realidade, a partir do contexto sociocultural, que se torna possível compreendermos o processo de geração, organização e disseminação das culturas matemáticas como forma de manutenção da tradição construída e partir para novos exercícios de criatividade na reinvenção da cultura matemática na escola, praticando cotidianamente uma renovação sociocognitiva no exercício da docência (2014, p.45).

Desse modo, podemos estabelecer algumas considerações a propósito das várias possibilidades de exercícios de criatividade que a inserção da matemática sensível do barro pode promover num curso de formação de professores na universidade, tendo como objetivo a reinvenção da cultura matemática. Neste processo de reinvenção o currículo tem necessariamente que fundar suas bases no terreno do pensamento complexo, aliando a incerteza, a organização sistêmica, o anel recursivo e o princípio hologramático (Morin, 2000) como norteadores no desenvolvimento de seus objetivos.

A incerteza como princípio desenvolve nossa capacidade de enfrentar o novo: "como definir o acaso que é um ingrediente inevitável de tudo o que nos surge como desordem? " (Morin, 2001, p. 178). A incerteza nos aponta para esta relação intrínseca entre a ordem e a desordem, onde as certezas deterministas foram abaladas e o que resta são apenas possibilidades que nos permitem conduzir nosso olhar. A organização sistêmica concebe o todo e as partes ligados de forma intensa, não permitindo que o dissecamento das partes gere o conhecimento do todo, "do átomo à estrela, da bactéria ao homem e à sociedade, a organização do todo produz qualidades ou propriedades novas em relação às partes consideradas isoladamente: as emergências" (Morin, 2000, p.).

O anel recursivo é um tipo de organização em que os efeitos agem sobre as causas e, portanto, o que era reação torna-se ação e assim desenvolve-se novas possibilidades que inicialmente não haviam sido consideradas: "a organização recursiva é a organização cujos efeitos e produtos são necessários a sua própria causação e a sua própria produção" (Morin, 2001, p. 182). Um holograma é uma estrutura em que as informações do todo repetem-se quase 
inteiramente nas partes, portanto o princípio hologramático prevê que não apenas o todo contém as partes, mas que as partes contém o todo, ou seja, "cada célula é parte do todo organismo global - mas o próprio todo está na parte: a totalidade do patrimônio genético está presente em cada célula individual; a sociedade como todo, aparece em cada indivíduo, através da linguagem, da cultura, das normas" (MORIN, 2000, p. 10).

Os princípios norteadores do pensamento complexo tornam o processo de ensino e de aprendizagem uma rede de conexões intensamente ligadas onde o fluxo de informações, conhecimento e emoções não possuem apenas uma via de transição, mas várias vias e intervias, assemelhando-se a uma teia, onde as ligações e interlocuções acontecem: "dessa perspectiva, cabe à educação o desafio de construir um ideário e uma prática de sociedade pautados pelos princípios da multiplicidade, da diversidade, da inclusão e da troca mais igualitária de experiências entre professores e alunos" (ALMEIDA, 2012, p. 195).

Considerando os princípios que regem o pensamento complexo o currículo em pauta possibilita novas construções a partir de uma Educação ainda baseada no paradigma da separação e da disjunção e que por isso mesmo necessita de uma reforma de pensamento.

\subsection{BASES PARA A CONSTRUÇÃO DA PROPOSTA DE DISCIPLINA}

Segundo Vergani (2007) uma disciplina de educação etnomatemática baseada na intenção de transformação da prática dos futuros professores e/ou pesquisadores deve necessariamente ser proposta como optativa, pressupondo um empenho pessoal para a sua realização. Tal disciplina poderá ser proposta tanto em cursos de licenciatura como em cursos de pósgraduação, o mais importante segundo a autora é o seu caráter transdisciplinar centrado nas ciências exatas e nas ciências humanas.

Nesta perspectiva a disciplina deve ser organizada em três fases: a primeira fase totalmente teórica deve ser desenvolvida com a apresentação dos principais conceitos da área, a segunda fase mista comporta tanto a discussão teórica como a prática partindo de pesquisas locais e a terceira e última fase constitui-se como exercício de investigação criativa, tendo como finalização a apresentação da pesquisa realizada.

Além disso, é importante a delimitação dos objetivos axiais e funcionais da disciplina (Vergani, 2007), os primeiros são as proposições fundamentais que norteiam as discussões na disciplina e os objetivos funcionais fomentam o desenvolvimento de determinadas capacidades, 
concretizando o que foi proposto como fundamental nos objetivos axiais. A dinâmica curricular da educação etnomatemática é regida pelos seguintes valores: "formativos (desenvolvimento do raciocínio), utilitários, sociológicos, culturais, estéticos e éticos” (Vergani, 2007, p. 46). Esta dinâmica deve utilizar uma metodologia que possibilite a tessitura de uma teia entre as dimensões teóricas, práticas, comunicacionais e avaliativas.

Segundo Moraes (2008) a postura ecossistêmica e complexa diante do mundo e da vida necessariamente deve impactar os ambientes educacionais, sendo assim:

[...] a dialogicidade dos processos, como característica da complexidade inerente aos sistemas vivos, reconhece a importância do imaginário e da intuição como fonte de informações relevantes para o conhecimento da realidade social, rompendo-se assim, com a divisão categórica entre racional/irracional, consciente/inconsciente, sentir/pensar/agir, categorias que não mais se repelem no processo de construção do conhecimento e no desenvolvimento da aprendizagem, mas se complementam e se enriquecem mutuamente (MORAES, 2008, p. 155).

A dinâmica curricular adotada na educação etnomatemática deve seguir este caminho traçado pela postura ecossistêmica e complexa convergindo para o que Vergani (2007) chama de "educação para o ambiente": "[...] não a partir das relações do homem com o meio natural, mas a partir das relações do homem com o domínio ecológico das suas capacidades lógicoracionais" (p.45). Este pensamento ecologizado capaz de promover o rompimento do paradigma da disjunção e da separação religando os saberes distintos: “ajuda-nos a romper o velho dogma reducionista de explicação do real, para perceber a complexidade entre o todo e as partes, entre o conhecimento científico e o senso comum, entre a ciência, a arte e as tradições" (Moraes, 2008, p. 187). Estas são as bases para a construção de uma disciplina da educação etnomatemática que possibilite o diálogo entre a matemática acadêmica, formal e a matemática espontânea de grupos culturais marginalizados, contudo esta disciplina não pode isoladamente ser suficiente para estabelecer uma mudança paradigmática no ambiente acadêmico. Ela se insere na perspectiva de "dízimo epistemológico ou transdisciplinar" concebido por Edgar Morin (2003) como responsável por estabelecer o solo fértil para que as mudanças possam acontecer.

\subsection{TECENDO OS FIOS}

Ao propormos pontes de contato entre a matemática acadêmica e a matemática da sensibilidade das artesãs do barro sabemos que o caminho se desenrola no próprio caminhar, como dito pelo poeta espanhol Antônio Machado (1875- 1939): “caminhante, não há caminho 
faz-se caminho ao andar" ${ }^{, 53}$, por isso mesmo uma disciplina com estas características deve ser desenvolvida com o propósito claro de estabelecer pontes entre conhecimentos distintos, mas que compartilham uma mesma matriz complexa de pensamento. Porém, não é possível descrever metodologicamente em detalhes quais são as possibilidades reais a serem alcançadas, pois a turma de alunos e de alunas que serão os sujeitos dessa proposta são elos importantes dessa teia. Suas histórias de vida, suas singularidades, seus propósitos com a matemática fazem parte desta teia, que é tecida por todos os integrantes, tanto pelos alunos e pelas alunas como pelas louceiras que poderão ser colaboradoras no processo, no sentido destacado acima, ou seja, como extensionistas colaboradoras. Neste aspecto, a colaboração das louceiras pode ser identificado como: “[...] uma nova convivência ativa de saberes no pressuposto que todos eles, incluindo o saber científico, se podem enriquecer nesse diálogo" (Santos, B., 2008, p.57).

A proposta de Teresa Vergani (2007) destaca a importância da investigação criativa como metodologia de abordagem, considerando uma aliança interdisciplinar entre a matemática com as ciências humanas, bem como utiliza a criatividade ao atender o sujeito holístico despertando seu potencial intuitivo e criativo na aprendizagem. Esta metodologia se aproxima do que Moraes e Torre (2004) apud Moraes (2008, p. 164) considera como sentipensar: "processo, mediante o qual se coloca para trabalhar conjuntamente o sentimento e o pensamento, a emoção e a razão, evidenciando assim, o quanto nossas estruturas cognitivas são irrigadas pelos nossos componentes emocionais, pelos nossos sentimentos e crenças”. O sentipensar como metodologia de aprendizagem permite ligações entre o formalismo e o rigor, característicos da matemática acadêmica com a emoção sentida pelo olhar, pelo intuir, pelo ouvir, tecendo uma malha de significados desvendada pela etnomatemática: “a etnomatemática partilha esta alternância rítmica de manifestações humanas, e abre-se tanto às energias subterrâneas do desejo como ao rigor do pensamento estruturante" (VERGANI, 2009, p.235).

Para Carlos Farias e Mendes (2014) a leitura etnomatemática do mundo supõe um olhar uno, múltiplo, globalizante e transversal dos fenômenos culturais e naturais por isso mesmo a aprendizagem acontece por meio das três dimensões: sociedade, cognição e cultura, sendo que o exercício de apreensão cultural, denominado aprendizagem pode ser definido como: “[...] aprender a olhar; aprender a pensar; aprender a imaginar; aprender a (re)criar; aprender a (re)ver, e pensar a matemática como um veículo da criatividade humana" (Farias, C.; Mendes, 2014, p.42). Ao estabelecermos que a metodologia do sentipensar possibilita a vivência da complexidade e da transdisciplinaridade, propomos a leitura globalizante e transversal dos

\footnotetext{
${ }^{53}$ Disponível em:<https://poesiaspreferidas.wordpress.com/2013/09/17/caminhante-antonio-machado/>. Acesso em 20 jan. 2016.
} 
fenômenos inscrita na proposição etnomatemática como uma possibilidade de transformação interior: "falar do sentipensar é falar de processos, de relações, de interações entre o mundo interior subjetivo e o exterior objetivo" (MORAES, 2008, p. 164).

Baseada nestes pressupostos é possível desenvolver uma disciplina etnomatemática que alie os seguintes aspectos: aliança entre a matemática e a antropologia, abertura transdisciplinar em todo seu contexto, significação trans-sociocultural e a eficácia plena da futura ação educativa (Vergani, 2007). Os objetivos inerentes apontam para a conjugação de dois olhares, o olhar epistemológico que abrange o conhecimento das áreas envolvidas e o olhar centrado no confronto entre racionalidade e a simbolicidade. A racionalidade representa não apenas o pensamento matemático, mas todo pensamento científico que repousa nesta vertente objetiva, e a simbolicidade fundamenta o uso dos símbolos como processo de entrelaçamento: “[...] os símbolos conseguem alcançar um entendimento totalizante e imediato que a razão só atinge através de aproximações sucessivas (tateantes). Suscitam pressentimentos tão integrais e inesgotáveis quanto o indizível para o qual apontam” (VERGANI, 2009, p. 98).

Este entrelaçamento entre a racionalidade e a simbolicidade caracteriza a atuação da Etnomatemática no processo de aproximação entre o Homo Sapiens e o Homo Signifer (Vergani, 2007) e é neste terreno que a matemática da sensibilidade das mulheres artesãs se inserem.

\subsection{A TEIA CONSTRUÍDA PELO OLHAR}

O meu primeiro contato estabelecido com a produção artesanal de Dona Pretinha e de Dona Andrelina foi por meio do movimento do olhar, em suas instâncias de ver, olhar e de ter visto (Dias, 2010), à medida que este movimento se fortaleceu como indagação surgiram várias bifurcações e caminhos sugerindo novos confrontos e questões: "Se nos aproximássemos ainda mais, perceberíamos que o que vemos não flutua no ar, está em relação, possui elos, estabelece alianças. Tudo entremeado, caótico e agenciado...rizoma" (Dias, 2010, p. 205), assim foi possível perceber que a Etnomatemática das louceiras de Arraias pode criar estreitos laços com a Ecologia de Saberes e adentrar o campus da UFT de Arraias reafirmando um antigo compromisso expresso no Manifesto Tocantins (2009): “[...] a necessidade premente de um diálogo criativo que suporte a complexidade dos problemas abordados a partir da ressignificação do mundo, que confere sentido e visibilidade a sua interdependência”.

As histórias de vida dessas duas mulheres, entremeadas com o barro, pontuadas por mitos e por recordações, são fios dessa teia, que às vezes parece um emaranhado confuso de sentidos, 
olhares e percepções. Porém, suas vidas e seus fazeres são testemunhas dessa sabedoria guardada em suas memórias, sendo recontada todas as vezes que uma botija, um pote ou uma fruteira é concluída e exposta às margens da rodovia esperando pelo olhar de admiração e reconhecimento dos transeuntes.

A sabedoria refletida em sua obra possui elementos estéticos, matemáticos e culturais (D’Ambrosio, 1998) permitindo que o olhar epistemológico capture um instantâneo desse saber e o transforme em conhecimento transdisciplinar, passível de estabelecer a justiça cognitiva aos saberes marginalizados como expresso por Boaventura Sousa Santos $(2006,2010)$ ao tratar da Ecologia de Saberes. A transformação e a própria transmissão desse saber marginalizado no âmbito do conhecimento transdisciplinar não são processos que permitam a metodologia formalizada nos moldes do paradigma da disjunção e da separação, parte dos princípios norteadores do pensamento complexo: “o conhecer e o aprender envolvem as dimensões sensoriais, intuitivas, emocionais, racionais e espirituais, dimensões não fragmentadas e nem dicotomizadas no ser humano, mas complementares na dinâmica operacional da construção de sua humanidade" (Moraes, 2008, p. 188). Por isso as instâncias do olhar possuem papel fundamental neste processo de conhecimento, pois: "ver é, por princípio, ver mais do que o que se vê, é aceder a um ser latente. O invisível é o relevo e a profundidade do visível" (MerleauPonty apud Novaes,1988, p. 14) e justamente a sedução estética das louças de Dona Andrelina e Dona Pretinha inicia-se por meio do olhar e a partir desse encontro outras possibilidades nascem, como o desvendar do invisto, o n[ã]o-visto, o invu.

Nesta zona fronteiriça tecida pela luminosidade das peças de barro branco, com a geometria oculta nas formas descritas na simetria de seus ornamentos, as louças das artesãs são traduzidas como elos de uma teia, inserida pela bricolagem no contexto histórico e social da cidade de Arraias, evocando antigos ritos de seu imaginário e recontando a história de suas ancestrais herdeiras da mesma tradição e detentoras do mesmo saber. Como ilustrado por Morin (2000, p. 6 ) no exemplo do copo de vinho do Porto: "Dito de outra maneira, num copo de vinho do Porto temos toda a história do Cosmos e, simultaneamente, a originalidade de uma bebida encontrada apenas na região do Douro", parafraseando o pensador podemos afirmar, sem sombra de dúvida, que as louças de Dona Pretinha e Dona Andrelina contam a história do Cosmos, na mesma perspectiva do copo de vinho, ao mesmo tempo em que as partículas que constituem a argila são compostas de elementos químicos primitivos e a técnica desenvolvida na sua confecção esteja escondida no tempo, a sua estrutura estética e artística preserva todos estes componentes recriando sua história todos os dias. 
A Etnomatemática como ponte entre os saberes despertados pelo olhar permite a convergência entre várias indagações: "sensível (naturalmente) à própria matemática entendida como processo de entendimento, comunicação e socialização são simultaneamente sensíveis à pessoa humana entendida como sujeito/espaço/tempo" (Vergani, 2009, p. 219), neste convergir a matemática e a antropologia conjugam estreita relação num processo simbiótico em que a Ecologia de Saberes surge como a interseção de todos estes universos.

A interseção promovida pela Ecologia de Saberes está baseada na “[...] independência complexa entre os diferentes saberes que constituem o sistema aberto do conhecimento em processo constante de criação e renovação. O conhecimento é interconhecimento, é reconhecimento, é autoconhecimento" (Santos, B., 2006, p. 157), os elos desta teia nos permitem retomar o pensamento renascentista de Giordano Bruno onde: "os olhares são as razões pelas quais o objeto (como se ele nos olhasse) se faz presente em nós" (Bruno, apud Novaes, 1988, p. 17), por meio do movimento do olhar a etnografia das louceiras de Arraias enredou-me em sua teia.

\subsection{CONSIDERAÇÕES FINAIS}

Minha pesquisa iniciou seu percurso tomando como referência as possibilidades despertadas pelo convergir entre a Ecologia de Saberes e a Etnomatemática, considerando que a partir desse encontro novos cenários se descortinam e novas possibilidades poderão ser desvendadas. Partindo do olhar-em-paisagem desencadeado por meio do meu contato com o artesanato de barro de Dona Pretinha e de Dona Andrelina, as indagações que se colocaram como norteadoras de minha pesquisa foram sendo respondidas e a questão central sobre o conhecimento etnomatemático envolvido nos saberes das artesãs pode ser respondida através da matemática da sensibilidade.

A matemática da sensibilidade é a convergência entre o pensamento matemático formal do pesquisador e a arte (e/ou técnica) desenvolvida por diferentes grupos ou sujeitos cognitivos nos seus fazeres e saberes tradicionais. Baseia-se na concepção de que estes saberes tradicionais, traduzidos em diferentes formas de artesanato, construção de barcos e de moradias, confecção de tijolos de adobe, entre outros, são desenvolvidos por meio de uma simbiose entre o pensamento simbólico/matemático não formal e a capacidade sensível e criativa do sujeito, ou seja, na execução do modelo transmitido oralmente por seus antecessores, existe o despertar 
de uma sensibilidade em medir, quantificar, sistematizar distinta dos padrões normalmente aceitos pela ciência atual, mas que permitem o diálogo com a matemática formal e acadêmica, podendo inclusive orientar processos de ensino, pesquisa e extensão na universidade.

A princípio, a matemática da sensibilidade desenvolvida pelas louceiras Dona Pretinha e Dona Andrelina precisa abrir espaço no universo acadêmico da UFT/Campus de Arraias, interferindo diretamente na formação dos futuros professores de matemática, instalando a compreensão das diversidades culturais no seio das ciências exatas. Mas, também é necessário construir pontes, formar elos que tornem a inserção dos saberes tradicionais uma realidade presente e cotidiana nos espaços da UFT em toda sua extensão, não somente no curso de Licenciatura em Matemática do campus de Arraias, retomando as perspectivas apontadas por vários momentos significativos dessa instituição como o clima vivido durante a realização do Seminário Internacional Distintos Olhares em 2009 que culminou com a proposta da reforma de pensamento acordada pelo "Manifesto Tocantins" (Ward, 2015).

A UFT precisa propiciar o ambiente necessário para que os saberes da tradição comunguem do mesmo espaço epistêmico que o conhecimento científico e para isso a proposta de extensionista colaborador aponta como recurso a ser considerado: "compreender que as interpretações e as teorias científicas, tanto quanto as mitologias e os saberes da tradição são sempre mais ou menos do que os fenômenos aos quais se referem configuram hoje um estilo cognitivo em construção" (Almeida, 2010, p. 150). O papel do extensionista colaborador preenche algumas lacunas abertas pela exclusão dos saberes de vários grupos do ambiente acadêmico, tornando a inserção social discutida pela Avaliação Internacional promovida pela ORUS uma realidade cotidiana na universidade.

Além dos saberes tradicionais presentes na confecção do artesanato das louceiras de Arraias, existem outras formas de manifestações artísticas-artesanais no estado de Tocantins que merecem ser reconhecidas como conhecimento pertinente, assumindo destaque no ambiente acadêmico. Algumas delas como a ourivesaria de filigrana de ouro da cidade de Natividade e o artesanato de capim dourado da Comunidade Quilombola Mumbuca da cidade de Mateiros, no Parque Estadual do Jalapão são exemplos destes saberes que configuram a identidade cultural de uma comunidade e podem ser abordados pela Etnomatemática, conjugando os elementos culturais, antropológicos e matemáticos aos quais remetem.

A preocupação axial deste trabalho se insere na perspectiva de resgate dos elementos centrais do Seminário Internacional Distintos Olhares que são a transição de paradigma e de como a universidade pode contribuir nesta transição, como também nos elementos basilares das conclusões da Avaliação Internacional promovida pela ORUS no campus da UFT/Palmas na 
dimensão da inserção social. Partindo destes pressupostos é possível reorientar os caminhos desta jovem universidade para que a Ecologia de Saberes se torne uma prática cotidiana em seu meio acadêmico e que a Etnomatemática possa se traduzir numa ferramenta necessária e suficiente para promover o diálogo entre a cultura científica e a cultura humana, como anuncia o pensador Edgar Morin, tendo em vista que a UFT em sua trajetória se colocou como lócus na consolidação de espaços de intercâmbio entre a cultura e os saberes locais.

As propostas apresentadas neste trabalho, tanto a inserção da matemática da sensibilidade das louceiras de Arraias no currículo do curso de Licenciatura em Matemática do campus de Arraias, como a implantação da atividade de extensionista colaborador na instituição apontam para a retomada da vocação da UFT como agregadora de distintos saberes, haja vista sua constituição multicampi estendendo-se por todo o estado de Tocantins, onde se localizam quatro grande biomas brasileiros com uma população constituída por comunidades ribeirinhas, quilombolas, etnias indígenas e que certamente influem e orientam as pesquisas e projetos desenvolvidos. Como bem pontuado por Othon Leonardos (Leonardos, Costa, 2008, p.106): "esse lar, onde crescem os frutos da conversa entre todos os saberes e entre as diferentes verdades de cada cultura é o espaço que nos pode conduzir ao verdadeiro multiculturalismo brasileiro", portanto o desafio que se interpõe é a construção dessa conversa mediada pela Ecologia de Saberes e pela Etnomatemática. 


\section{REFERÊNCIAS :}

ACSELRAD, Maria. A transmissão de saberes no contexto das culturas populares e tradicionais. In: Encontro Nacional de pesquisadores em Dança - Dança: contrações epistêmicas. 2., 2011, São Paulo. São Paulo. Anais. São Paulo: Anda, 2011. Disponível em: <http://www.portalanda.org.br/anaisarquivos/1-2011-19.pdf> Acesso em: 30 set. 2015.

ALMANAQUE CULTURAL DO TOCANTINS. Palmas. Ano 03. Número 17. Abril, 2001.

ALMEIDA, Maria da Conceição de. Complexidade, saberes científicos, saberes da tradição. São Paulo: Livraria da Física. 2010. 175 p.

Maria da Conceição de. Ciências da Complexidade e Educação: razão apaixonada e politização do pensamento. Natal: EDUFRN, 2012. 272 p.

APOLINÁRIO, Juciene Ricarte. Escravidão negra no Tocantins: vivências escravistas em Arraias (1739-1800). 2 ed. Goiânia: Kelps.2007. 121 p.

AUGÉ, Marc. Não-lugares-Introdução a uma antropologia da supermodernidade. Campinas: Papirus, 1994.

BHABHA, Homi K. O local da cultura. Belo Horizonte: Editora UFMG, 2007.

BARBIERO, Alan. Apresentação. In: NASCIMENTO, Elimar Pinheiro, PENA-VEGA, Alfredo (Orgs.). As novas dimensões da universidade: Interdisciplinaridade, sustentabilidade e inserção social. Rio de Janeiro: Garamond, 2012. p. 7-8.

BASSANEZI, Rodney Carlos. FARIA, Maria Salett Biembegutt. A matemática dos ornamentos e a cultura Arica. Revista de Ensino de Ciências. v. 21. n. 21. p. 39- 45. Set.1988. Disponível em:

<http://www.cienciamao.usp.br/tudo/exibir.php?...amatematicadosornamentos>. Acesso em 25 set. 2015.

BIANCHI, Françoise. O caminho do método. In: PENA-VEGA, Alfredo. NACIMENTO, Elimar (Orgs.). O pensar complexo: Edgar Morin e a crise da modernidade. Rio de Janeiro: Garamond. 2010. p. 119-127.

BIEMBEGUT, Maria Salett. Modelagem Matemática \& implicações no ensino e na aprendizagem da Matemática. Blumenau, 2 Ed. Edfurb. 2004. 
BOSI, Alfredo. Fenomenologia do Olhar. In: NOVAES, Adauto et al. O Olhar. São Paulo: Companhia das Letras, 1988. p. 65-87.

BOSI, Ecléa. Memória e sociedade: lembranças de velhos. 3 ed. São Paulo: Companhia das Letras, 1994.

BUARQUE, Cristovam. A aventura da universidade. 2 ed. Rio de Janeiro: Editora da Universidade Estadual Paulista, Paz e Terra, 1994. 239 p.

CAPRA, Fritjof. A teia da vida: uma nova compreensão dos sistemas vivos. São Paulo: Cultrix. 2006.

CAMPBELL, Joseph. O poder do mito. São Paulo: Palas Athena. 1990.

CARRIZO, Luís et al. Reflexões finais. In: NASCIMENTO, Elimar Pinheiro, PENA-VEGA, Alfredo (Orgs.). As novas dimensões da universidade: Interdisciplinaridade, sustentabilidade e inserção social. Rio de Janeiro: Garamond, 2012. p. 169-177.

CARVALHO, Doracy Dias Aguiar de. A política de cotas da Universidade Federal do

Tocantins: concepção e implicações para a permanência dos estudantes indígenas 2010. 179 f. Dissertação (Mestrado em Educação). Faculdade de Educação da Universidade Federal de Goiás. Goiânia. 2010. Disponível em:〈https://ppge.fe.ufg.br/up/6/o/Dissert-\%20Doracy.pdf> Acesso em 07 jul. 2015.

CASTORIADIS, Cornelius. A instituição imaginária da sociedade. Rio de Janeiro: Paz e Terra. 1982. (Col. Rumos da Cultura Moderna, v. 52).

CHALUB MARTINS, Leila. Memória e meio ambiente: a experiência com as mulheres das águas. In: Encontro da Associação Nacional de Pós-Graduação e Pesquisa em Ambiente e Sociedade, $\mathbf{1}^{\mathbf{0}}, 2002$, Indaiatuba (SP). Anais do Encontro da Associação Nacional de PósGraduação e Pesquisa em Ambiente e Sociedade. p. 1-14.

CHAUÍ, Marilena. Janela da alma, espelho do mundo. In: NOVAES, Adauto et al. O Olhar. São Paulo: Companhia das Letras, 1988. p. 31-63.

CHAUÍ, Marilena. Escritos sobre a universidade. São Paulo: Unesp. 2001. Disponível em: <https://uspcaf.files.wordpress.com/2011/11/escrito-sobre-a-universidade.pdf>. Acesso em 25 fev. 2014. 
CENTRO de Desenvolvimento Sustentável. Mulheres das Águas e o Desenvolvimento Sustentável: reflexões sobre a prática. Brasília, 2010. Slides.

CORDEIRO, Rosolinda Batista de Abreu. Arraias: Suas raízes e sua gente. Goiânia, 1989. $243 \mathrm{p}$.

COSTA, Helena Araújo. NASCIMENTO, Elimar Pinheiro. Benchmarking internacional de práticas interdisciplinares: o caso das universidades. In: NASCIMENTO, Elimar Pinheiro, PENA-VEGA, Alfredo (Orgs.). As novas dimensões da universidade: Interdisciplinaridade, sustentabilidade e inserção social. Rio de Janeiro: Garamond, 2012. p.39-76.

COSTA, Magda Suely Pereira. Educação e Cultura de Arraias. Palmas: Secretaria de Comunicação. 2004.

Magda Suely Pereira. Poder Local em Tocantins: domínio e legitimidade em Arraias. 2008. 298 f. Tese de Doutorado em Sociologia. Programa de Pós-Graduação em Sociologia do Departamento de Sociologia da Universidade de Brasília. Brasília. 2008. Disponível em:<http://repositorio.unb.br/handle/10482/1863> Acesso em 28 jan. 2015.

D’AMBROSIO, Ubiratan. Etnomatemática. São Paulo: Ática, 1998. 88 p.

, Ubiratan. Etnomatemática: Elo entre as tradições e a modernidade. 3 ed. Belo Horizonte: Autêntica, 2009. 112 p.

Ubiratan. A prática transdisciplinar na universidade. 2012. Disponível em: $<$ https://drive.google.com/a/mail.uft.edu.br/file/d/0B4JIJny__7pN2YxNGUyMzMtMDE2Yi00MDhiLTlhZDktMzQwNGNjMGYwZGZk/view?pli=1>. Acesso em 29 out. 2013.

, Ubiratan. Como foi gerado o nome Etnomatemática ou Alustapasivistykselitys. In:

Encontro de Etnomatemática do Rio de Janeiro, 2014. Anais do Encontro de Etnomatemática do Rio de Janeiro, 2015. p. 14-22. Disponível em: <file:///C:/Users/UFT/Downloads/Apresenta\%C3\%A7\%C3\%A3o_etnomat_rj.pdf>. Acesso em 26 jan. 2015.

DIAS, Karina. Entre visão e invisão: paisagem (por uma experiência da paisagem no cotidiano). Brasília: Programa de Pós-Graduação em Arte, Universidade de Brasília, 2010.

ELIADE, Mircea. Mito e Realidade. São Paulo: Perspectiva. 1991. (Col. Debates). 
1992.

, Mircea. O sagrado e o profano: a essência das religiões. São Paulo: Martins Fontes.

FARIAS, Carlos Aldemir. MENDES, Iran Abreu. As culturas são as marcas das sociedades humanas. In: MENDES, Iran Abreu. FARIAS, Carlos Aldemir (Org.). Práticas

Socioculturais e Educação Matemática. São Paulo: Livraria da Física. 2014. (Col. Contextos da Ciência).

FARIAS, Marizeth Ferreira. Mudanças e impactos causados pela presença da Universidade Federal do Tocantins em Arraias e região: uma perspectiva histórica. In: Anais do III Congresso Internacional de História da UFG, 2011. Jataí. p.1-8. Disponível em:<http://www.congressohistoriajatai.org/anais2011/link\%2028.pdf> Acesso em 10 jun. 2015 .

Marizeth Ferreira. Universidade Federal do Tocantins (Campus de Arraias): história, expansão e perspectivas atuais. 2013. 157 f. Dissertação (Mestrado em Educação). Programa de Pós-Graduação em Educação, Pontifícia Universidade Católica de Goiás, Goiânia, 2013. Disponível em: $<$ http://tede.biblioteca.ucg.br/tde_busca/arquivo.php?codArquivo=1600>. Acesso em 06 ago. 2015.

FERNANDES, Alcione Marques; MARTINS, Leila Chalub. Movimento do olhar: uma experiência etnomatemática. In: Encontro de Etnomatemática do Rio de Janeiro, 2014. Anais do Encontro de Etnomatemática do Rio de Janeiro, 2015. p. 482-490. Disponível em:<file:///C:/Users/UFT/Downloads/Apresenta\%C3\%A7\%C3\%A3o_etnomat_rj.pdf>. Acesso em 26 jan. 2015.

FRATE, Claudio Albuquerque; VICENTIM, Fabiana Moreira; CHALUB MARTINS, Leila. Inserção social e universidades brasileiras: as melhores práticas. NASCIMENTO, Elimar Pinheiro, PENA-VEGA, Alfredo (Orgs.). As novas dimensões da universidade: Interdisciplinaridade, sustentabilidade e inserção social. Rio de Janeiro: Garamond, 2012. p. 113-141.

FUNDAÇÃO UNIVERSIDADE FEDERAL DO TOCANTINS. Avaliação Institucional interna da UFT-2006: relatório final. Palmas: 2007. 98 p.

FUNDAÇÃO UNIVERSIDADE FEDERAL DO TOCANTINS. Relatório de Avaliação Institucional interna da UFT 2009-2010. Palmas: 2010. $200 \mathrm{f}$.

FUNDAÇÃO UNIVERSIDADE FEDERAL DO TOCANTINS. Proposta de consolidação e expansão do Câmpus de Arraias. Arraias, 2013. 30 p. 
GALEFFI, Lígia Maria Larcher. Patrimônio edificado: um livro em forma de arquitetura. Salvador: IPAC, 2010. Disponível em:<http://www.ipac.ba.gov.br/site>. Acesso em 12/03/2015.

GERDES, Paulus. Etnomatemática e Educação Matemática: uma panorâmica geral. Quadrante. Lisboa, vol. 5, n. 2, p. 105-138. Disponível em: <http://heema.org/wpcontent/uploads/2011/05/pg-FE-USP-Explora\%C3\%A7\%C3\%A3o-2.pdf >. Acesso em: 01 dez. 2015.

Paulus. Etnogeometria: cultura e o despertar geométrico. Belo Horizonte/ Moçambique: Instituto Superior de Tecnologias de Gestão. 2012. Disponível em: $<$ http://www.lulu.com/shop/paulus-gerdes/etnogeometria-cultura-e-o-despertar-dopensamento-geom\%C3\%A9trico-ebook/ebook/product-21323815.html>. Acesso em $09 \mathrm{dez}$. 2015.

HORTA, Maria de Lourdes Parreira. A memória pública. Cursos Miniweb Educação. Disponível em <http://www.miniweb.com.br/educadores/Artigos/lugares_memoria.html>. Acesso em 19 nov. 2015.

INSTITUTO BRASILEIRO DE GEOGRAFIA E ESTATÍSTICA. Cidades 2015. 2015. Disponível em:<http://www.cidades.ibge.gov.br/xtras/perfil.php?lang=\&codmun=170240>. Acesso em: 20 out. 2015.

JULLIEN, François. O diálogo entre as culturas: do universal ao multiculturalismo. Rio de Janeiro: Jorge Zahar, 2009.

KNIJNIK, Gelsa. Pesquisa em Etnomatemática: apontamentos sobre o tema. In: Congresso Brasileiro de Etnomatemática. 3. 2008.Niterói. Anais.... Niterói. 2008. ISBN: $858999404-$ X. p. 1-12.

LEBRUN, Gerard. Sombra e luz em Platão. In: NOVAES, Adauto et al. O Olhar. São Paulo: Companhia das Letras, 1988. p. 21-30.

LEONARDOS, Othon Henry, COSTA, Renata Oliveira. Dialogando com saberes da terra para a sustentabilidade da vida. In: NASCIMENTO, Elimar, PENA-VEGA, Alfredo, SILVEIRA, Márcio Antônio da (org.). Interdisciplinaridade e Universidade no Século XXI. Brasília: Abaré, 2008. p. 103-117.

LÉVI-STRAUSS, Claude. O Pensamento Selvagem. São Paulo: Companhia Editora Nacional, 1976. 331 p. 
, Claude. O cru e o cozido. São Paulo: Cosac \& Naify, 2004. (Col. Mitológicas v.1).

LOMBARDI, Luana. Dona Andrelina. 2010. 2 fotografia.

LOSADA, Manuel. O imaginário radical de Castoriadis seus pressupostos. In: AZEVEDO, Nyrma Souza Nunes de (Org.). Imaginário e Educação: reflexões teórica e aplicações. Campinas: Alínea, 2006.

LUDEWIGS, Thomas. AZEVEDO, Aldemir Inácio de. A experiência da interdisciplinaridade na Universidade Federal do Tocantins. NASCIMENTO, Elimar Pinheiro, PENA-VEGA, Alfredo (Orgs.). As novas dimensões da universidade: Interdisciplinaridade, sustentabilidade e inserção social. Rio de Janeiro: Garamond, 2012. p. 77-111.

MACEDO, Roberto Sidinei. A etnopesquisa implicada: pertencimento, criação de saberes e afirmação. Brasília: Liber Livro, 2012. 168 p.

MIARKA, Roger. Etnomatemática: do ôntico ao ontológico. 2011. 427 f. Tese (Doutorado em Educação Matemática). Instituto de Geociências e Ciências Exatas da Universidade Estadual Paulista Júlio de Mesquita Filho. Rio Claro. 2011. Disponível em <http://etnomatematica.org/tesis_doctorado/Tese-Miarka-2011.pdf> Acesso em 11 dez. 2014.

, Roger. Descrições em Etnomatemática: descrevendo "a matemática de uma prática" ou "uma prática matematicamente"? Revista Latinoamericana de Etnomatemática, Departamento de Matemáticas y Estadística. Universidad de Nariño. vol. 6, n. 2. p. 35-47, 2013. Disponível em <http://www.revista.etnomatematica.org/index.php/RLE/article/view/70>. Acesso em 07 jan. 2015.

MORAES, Maria Cândida. Pensamento Eco-Sistêmico: educação, aprendizagem e cidadania no século XXI. Petrópolis: Vozes, 2004. 343 p.

MORAES, Maria Cândida. Ecologia de Saberes: complexidade, transdisciplinaridade e educação: novos fundamentos para iluminar novas práticas educacionais. São Paulo: Antakarana/WHH- Willis Harman House, 2008.

MOREIRA, Darlinda. Etnomatemática e mediação de saberes matemáticos na sociedade global e multicultural. In: Congresso Brasileiro de Etnomatemática. 3. 2008.Niterói. Anais.... Niterói. 2008. ISBN: 858999404-X. p. 1-12. 
MORIN, Edgar. O Método 3: O conhecimento do conhecimento. 2 ed. Porto Alegre: Sulina. 1999.

Edgar. Da necessidade de um pensamento complexo. In: MARTINS, Francisco

Menezes; SILVA, Juremir Machado da. (Org.). Para navegar no século XXI: tecnologias do imaginário e Cibercultura. Porto Alegre: Sulina/Edipucrs. 2000. Disponível em:

$<$ http://romanticos-conspiradores.ning.com/page/livros-e-artigos-para-download> Acesso em 23 nov. 2015.

Edgar. Ciência com consciência. 5 ed. Rio de Janeiro: Bertrand Brasil, 2001.

Edgar. A cabeça bem-feita: repensar a reforma, reformar o pensamento. 8 ed. Rio de Janeiro: Bertrand Brasil, 2003. 128 p. Disponível

em:<http://www.moodle.ufba.br/file.php/11468/Ed-gar_Morina_cabeA_a_bem_feita_pdf >. Acesso em 05 jun. 2015.

Edgar. Educação e complexidade: os sete saberes e outros ensaios. 5 ed. São Paulo: Cortez, 2009a.

Edgar. Seminário Internacional Distintos olhares. O Girassol. Palmas, 24 jun. 2009b. Disponível em: <http://serranoecia.blogspot.com.br/2009/07/unidade-da-diversidadehumana-na-visao.html>. Acesso em 07 jul. 2015

Edgar. Por uma reforma do pensamento. In: PENA-VEGA, Alfredo. NACIMENTO, Elimar (Org.). O pensar complexo: Edgar Morin e a crise da modernidade. Rio de Janeiro: Garamond. 2010a. p. 21-34.

Edgar. CARVALHO, Edgar. Prefácio. In: ALMEIDA, Maria da Conceição de. Complexidade, saberes científicos, saberes da tradição. São Paulo: Livraria da Física. 2010b. p. 15-16.

, Edgar. O Método 4: As ideias: vida, costumes, organização. 6 ed. Porto Alegre: Sulina. 2011.

MUSEU HISTÓRICO E CULTURAL DE ARRAIAS. Disponível em: <http://encantosdocerrado.com.br/n/770> . Acesso em 12 ago. 2015.

NASCIMENTO, Elimar Pinheiro, PENA-VEGA, Alfredo (Orgs.). As novas dimensões da universidade: Interdisciplinaridade, sustentabilidade e inserção social. Rio de Janeiro: Garamond, 2012. 178 p. 
NOVAES, Adauto. De olhos vendados. In: NOVAES, Adauto et al., O Olhar. São Paulo: Companhia das Letras, 1988. p. 9-20.

OLIVEIRA, Roberto Cardoso de. O trabalho do antropólogo: olhar, ouvir, escrever. In: O trabalho do antropólogo. 2.ed. SP: UNESP/Paralelo 15, 2000. p.17-36. Disponível em:<file://C:/Users/UFT/Downloads/OLIVEIRA,\%20Roberto\%20Cardoso\%20de.\%200\%2 0trabalho\%20do\%20antropologo\%20[livro\%20completo].pdf >. Acesso em 21 set. 2015.

OLIVEIRA, Rosy de. O Barulho da Terra: Nem Kalunga Nem Camponeses. 2007. 230 f. Tese (Doutorado em Sociologia e Antropologia). Instituto de Filosofia e Ciências Sociais da Universidade Federal do Rio de Janeiro. Rio de Janeiro. 2007. Disponível em $<$ http://www.ppgsa.ifcs.ufrj.br/teses-e-dissertacoes/o-barulho-da-terra-nem-kalunga-nemcamponeses/>. Acesso em 06 abr. 2015.

OSTROWER, Faya. A construção do olhar. In: NOVAES, Adauto et al. O Olhar. São Paulo: Companhia das Letras, 1988.

PEDREIRA, Antônia Custódia. et al.. Arqueologia e Patrimônio: um olhar sobre a história e a cultura dos municípios de Peixe, Arraias, Paranã e Taguatinga, no Estado do Tocantins. Palmas: Exata Copiadora, 2012. 160 p.

PENA-VEGA, Alfredo. A crise civilizacional: olhares do sul. In: WARD, Rodolfo. (Org.). Wawekrurê: distintos olhares. Brasília: Senado Federal, 2015.p. 16-19. (v. 213)

PEREIRA, Cícero Valdiêr. Política de acesso e permanência para estudantes indígenas na Universidade: avaliação da política de cotas da Universidade Federal do Tocantins (UFT), 2011. 183 f. Dissertação (Mestrado Profissional em Avaliação de Políticas Públicas). Universidade Federal do Ceará, Fortaleza, 2011. Disponível em: <http://www.mapp.ufc.br/images/disserta\%C3\%B5es/2011/C\%C3\%8DCERO-VALDIERPEREIRA.pdf $>$. Acesso em 07 jul. 2015.

PIDNER, Flora Sousa. Diálogos entre Ciência e Saberes Locais: dificuldades e perspectivas. 2010. 145 f. Dissertação (Mestrado em Geografia). Instituto de Geociências. Universidade Federal de Minas Gerais. Belo Horizonte. 2010. Disponível em $<$ http://www.bibliotecadigital.ufmg.br/dspace/.../disserta_o_vers_o_final.pdf?> Acesso em 10 fev. 2014.

RAMOS, Joana Vilar Ramalho. CABRAL, Alberto dos Santos. A pegada ecológica da UFT. In: NASCIMENTO, Elimar Pinheiro, PENA-VEGA, Alfredo (Orgs.). As novas dimensões da universidade: Interdisciplinaridade, sustentabilidade e inserção social. Rio de Janeiro: Garamond, 2012. p. 13-37. 
RAMALHO, Anita. Relembrando. Anápolis: Atlas. 2012. 186 p.

RIBEIRO, Darcy. A universidade necessária. 3 ed. Rio de Janeiro: Paz e Terra, 1978.

ROCHA-COELHO, Fabiane Borges. O uso das plantas no cotidiano da comunidade quilombola kalunga do Mimoso - Tocantins: um estudo etnobotânico. 2009. 110 f. Dissertação (Mestrado em Ciências do Ambiente). Universidade Federal do Tocantins. 2009.Disponível em

<http://www.dominiopublico.gov.br/pesquisa/DetalheObraForm.do?select_action=\&co_obra $=174802>$. Acesso em 03 abr. 2014.

ROCHA, Saulo da. CARLOTO, Denis Ricardo. A caverna Lapa do Bom Jesus em Arraias Tocantins e as representações da comunidade quilombola Lagoa da Pedra. In: Congresso Brasileiro de Espeleologia, 31. 2011. Ponta Grossa. p. 269-276. Disponível em <http://www.sbe.com.br/anais31cbe/31cbe_expediente.pdf>. Acesso em 19 jan. 2015. ROHDE, Geraldo Mário. Simetria. São Paulo: Hemus. 1982. 191 p.

ROSA, Milton; OREY, Daniel Clark. Aproximações da Etnomatemática com o programa de pesquisa de Lakatos. In: Encontro de Etnomatemática do Rio de Janeiro,1, 2014. Anais do Encontro de Etnomatemática do Rio de Janeiro, 2015. p. 190-198.Disponível em:

<file:///C:/Users/UFT/Downloads/Apresenta\%C3\%A7\%C3\%A3o_etnomat_rj.pdf>. Acesso em 26 jan. 2015.

SÁ, Sílvia Michele Macedo de. Povos indígenas em afirmação, caminhos etnográficos aprendentes e a compreensão cultural do fenômeno aprender. In: MACEDO, Roberto Sidinei. A etnopesquisa implicada: pertencimento, criação de saberes e afirmação. Brasília: Liber Livro, 2012. p. 75 - 86.

SANTOS, Boaventura Sousa. Pela mão de Alice: o social e o político na Pós-Modernidade.7 ed. Porto:Afrontamento. 1999. Disponível em:

$<$ http://josenorberto.com.br/SANTOS,\%20Boaventura\%20de\%20Souza.\%20Pela\%20M\%C3 $\%$ A3o $\% 20 \mathrm{de} \% 20$ Alice $\% 20 \mathrm{o} \% 20$ social $\% 20 \mathrm{e} \% 20 \mathrm{o} \% 20$ pol $\%$ C3\%ADtico $\% 20$ na $\% 20 \mathrm{p} \% \mathrm{C} 3 \%$ B3s-modernidade.pdf>. Acesso em 16 abr. 2014.

, Boaventura Sousa. A gramática do tempo: para uma nova cultura política. São

Paulo: Cortez. 2006. (Col. Para um novo senso comum, v. 4).

Boaventura Sousa. A Universidade do Século XXI: Para uma reforma democrática e emancipatória da Universidade. 2008. Disponível em: 
<http://www.ces.uc.pt/bss/documentos/auniversidadedosecXXI.pdf $>$. Acesso em 05 nov. 2010.

SANTOS, Redenir dos. Arraias, um portal para o além. Brasília: Projecto Editorial, 2002. $284 \mathrm{p}$.

SILVA, Norma Lúcia da. Caderno didático: História do Tocantins. Goiânia: Grafset, 2008.

SILVA, Rubens Ribeiro da. Uma informação. Mensagem recebida por: alcione@uft.edu.br 17 nov. 2015.

SILVEIRA, Márcio da. Contrastes da igualdade. In: WARD, Rodolfo. (Org.). Wawekrurê: distintos olhares. Brasília: Senado Federal, 2015. p. 19-22. (v. 213)

SOUZA, Rose Mara, Vidal de. Marco para um estado da Região Norte. In: WARD, Rodolfo. (Org.). Wawekrurê: distintos olhares. Brasília: Senado Federal, 2015.p.25-28. (v. 213)

STEWART, Ian. Uma História da Simetria na Matemática. Rio de Janeiro: Zahar, 2012. $346 \mathrm{p}$.

SUÁREZ, Myrea. Sertanejo: um personagem mítico. Revista de pesquisas e debates em Ciências Sociais: Sociedade e Cultura (UFG), Goiânia. vol.1, n. 1. p. 29-39, 1998.

Disponível em: <http://www.revistas.ufg.br/index.php/fchf/article/view/1777>. Acesso em 03 abr. 2015.

TESKE. Wolfang. A Roda de São Gonçalo na comunidade quilombola da Lagoa da Pedra em Arraias (TO): um estudo de caso de processo folkcomunicacional. Goiânia: Kelps, 2008. 180 p.

Wolfang. Cultura Quilombola na Lagoa da Pedra, Arraias -Tocantins: rituais, símbolos e rede de significados de suas manifestações culturais: um processo folkcomunicacional de saber ambiental. Brasília: Senado Federal, 2010. 296 p. (v. 146).

UNIVERSIDADE FEDERAL DO TOCANTINS. Resolução Consuni n⿳ 14/2013. Dispõe sobre a implantação do sistema de cota para os quilombolas em todos os cursos de graduação da Universidade Federal do Tocantins. Palmas, 2013. Disponível em: $<$ http://download.uft.edu.br/?d=877f8a02-5c4a-4c0c-95ce-792b9fe07b96;1.0:14-2013\%20$\% 20$ Cotas\%20Quilombolas.pdf> Acesso em: 24 out. 2015. 
VERGANI, Teresa. A criatividade como destino: Transdisciplinaridade, cultura e educação. São Paulo: Livraria da Física, 2009. 302 p.

VERGANI, Teresa. Excrementos do sol: a propósito de diversidades culturais. Lisboa: Pandora, 1995. 238 p.

VERGANI, Teresa. Educação Etnomatemática: o que é? Natal: Flecha do Tempo, 2007. 67 p.

WARD, Rodolfo. Wawekrurê: distintos olhares. Brasília: Senado Federal, 2015. (v. 213).

WEBER, Renée. Diálogos com cientistas e sábios: a busca da unidade. São Paulo: Cultrix. 1986.

ZAOUAL, Hassan. Globalização e diversidade cultural. São Paulo: Cortez. 2003. (Col. Questões de nossa época, 106). 
ANEXO A: MANIFESTO TOCANTINS

MANIFESTO TOCANTINS, 24 DE JUNHO DE 2009

\section{MANIFESTO TOCANTINS, 24 DE JUNHO DE 2009}

O Seminário Internacional Crise Civilizacional: Distintos Olhares - Transição de Paradigma de desenvolvimento nos Países do Sul debateu as diversas possibilidades de "mudança de via" de um modelo de desenvolvimento que, comprovadamente, encontra-se esgotado, pois continua provocando miséria e desigualdades, que colocam em risco as diferentes formas de vida no planeta. Nossas decisões e ações trarão consequêencias às gerações futuras, exigindo, de imediato, uma solidariedade intergeracional.

Apesar de os problemas atingirem dimensões globais, os impactos já se fazem evidentes nas populações do Sul, afetando, principalmente, aqueles que se encontram à margem de qualquer forma de cidadania. As mudanças climáticas provocadas pelo desenvolvimento interferem no presente e no futuro da humanidade.

Os participantes do Seminário buscaram responder, dentre outras questões, a seguinte pergunta: OUTRO MUNDO É POSSIVEL?

Podemos esperar um devir fraterno nas relaçōes dos diferentes povos e a natureza. Com este espírito, o Seminário refletiu sobre vias possiveis para o nosso futuro.

Essa mudança de via exige um envolvimento comprometido com a política, a ética e a estética. É imperativo romper com o modelo que perpetua a miséria econômica, humana e ambiental, que nos leva a catástrofes previsíveis.

A crise representa uma oportunidade e estímulo para a construção de outra visão de mundo e o desenho de cenários futuros. Precisamos estar abertos para identificar e dialogar com os distintos olhares que busquem uma definição de novas vias, pautadas na solidariedade e na fraternidade.

A consciência do pertencimento de uma cidadania planetária, baseada em conhecimentos e percepções distintas do problema, exige uma transformação nas relações humanas, como uma metamorfose que possibilita um novo destino da humanidade.

Os riscos mortais que ameaçam o nosso planeta Terra são evidentes. O Seminário de Palmas/Tocantins manifesta a necessidade premente de um diálogo criativo que suporte a complexidade dos problemas abordados a partir da ressignificação do mundo, que confere sentido e visibilidade a sua interdependência. 
ANEXO B: REGISTRO DE IMPRESSÕES SOBRE O SEMINÁRIO INTERNACIONAL DISTINTOS OLHARES

\section{Distintos Olhares}

Deixe sua Impressão sobre o Seminário Internacional Crise Civilizacional: Distintos Olhares
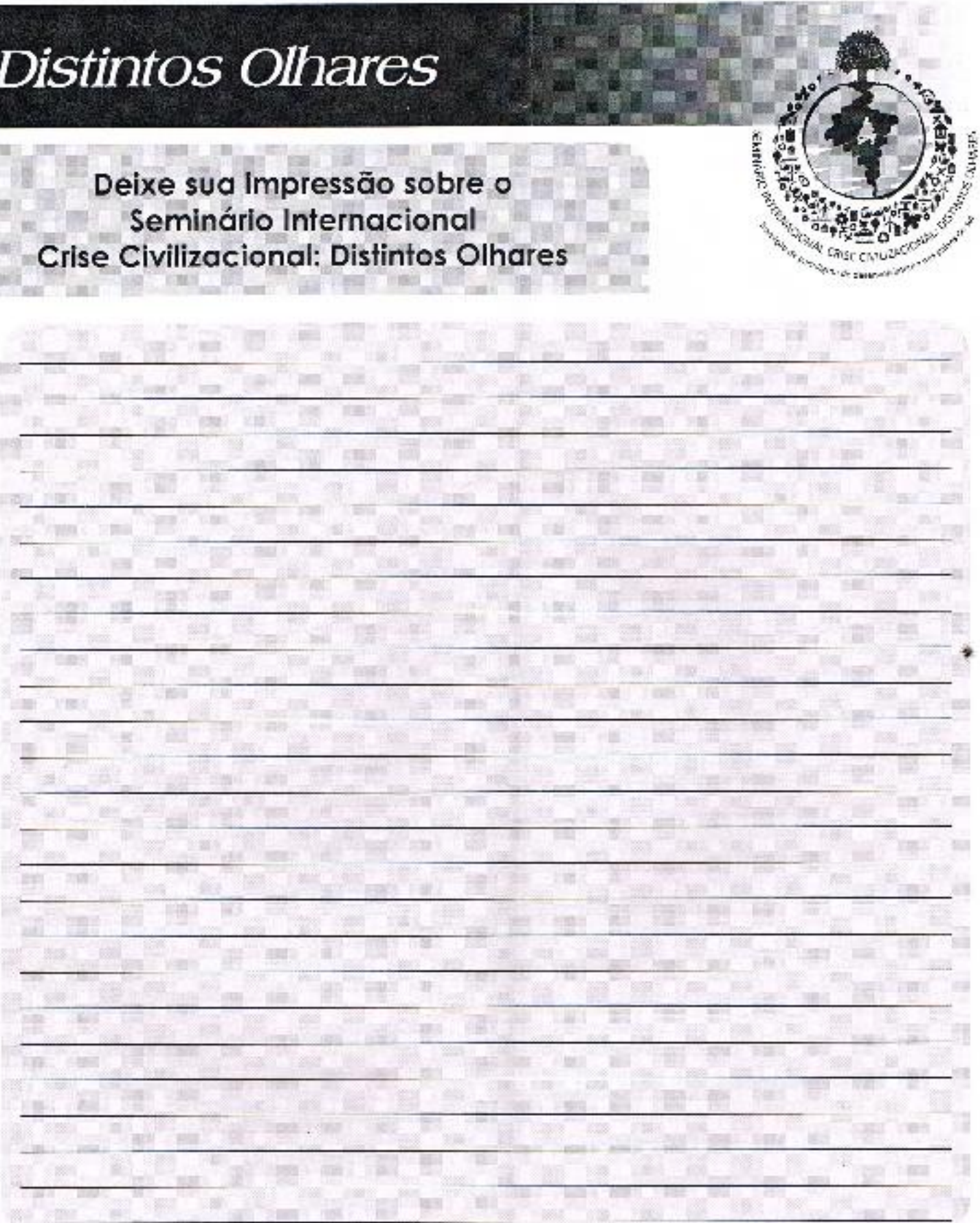

O seu depvimenio pode ser pubicado em livro, teito a partir do debate gerado pelo Saminario, promovido polos ocrceiros co evento.

Nome:

Contato:

Autorizo a publeaçāo ícssinaturaj: 
ANEXO C: DOUTOR HONORIS CAUSA EDGAR MORIN

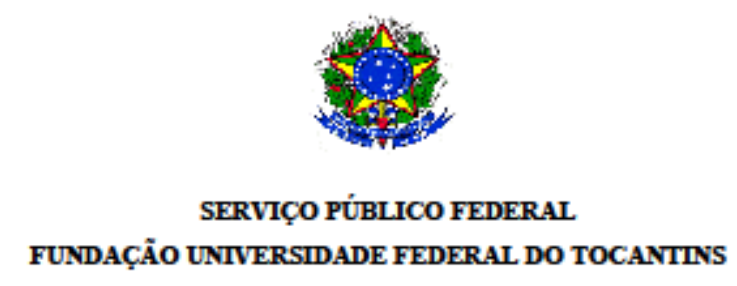

RESOLUÇÃO DO CONSELHO UNIVERSITÁRIO (CONSUNT)

$\mathrm{N}^{\circ} 04 / 2009$

Aprova a concessão do título de Doutor Honoris Canusa ao sociólogo e pensador francês Edgar Morin

O Conselho Universitário (CONSUNI) da Universidade Federal do Tocantins (UFT), no uso de suas atribuições legais e estatutárias, por indicação e relato do Magnifico Reitor, Professor Alan Barbiero, em sessão realizada no dia 27 de maio de 2009,

RESOLVE:

Art. $1^{\circ}$ - Aprovar a concessão do título de Doutor Honoris Causa ao sociólogo e pensador francês Edgar Morin.

Art. $2^{\circ}$ - Esta resolução entra em vigor a partir desta data.

Palmas, 27 de maio de 2009

Prof. Alan Barbiero

Presidente 
ANEXO D: DOUTOR HONORIS CAUSA DONA RAIMUNDA

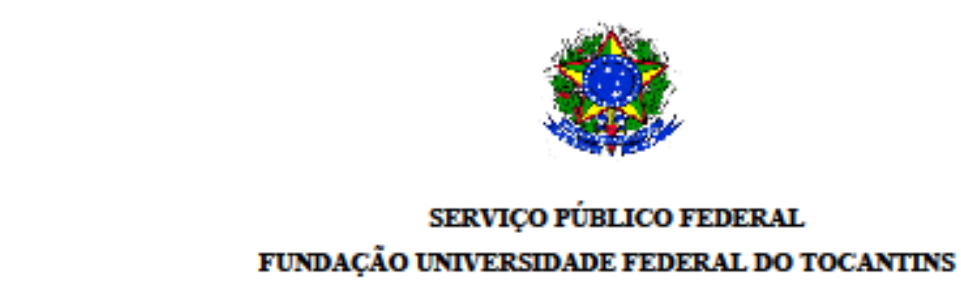

\title{
RESOLUÇÃO DO CONSELHO UNIVERSITÁRIO (CONSUNT)
}

$\mathrm{N}^{\circ} \mathbf{0 5} / \mathbf{2 0 0 9}$

Aprova a concessão do título de Doutora Honoris Causa à quebradeira de coco Dona Raimunda Gomes da Silva

O Conselho Universitánio (CONSUNI) da Universidade Federal do Tocantins (UFT), no uso de suas atribuições legais e estatutánias, por indicação do professor José Ramiro Lamadrid Maron, do Curso de Pedagogia da UFT, e com relato do Magnifico Reitor, em sessão realizada no dia 27 de maio de 2009 ,

\section{RESOLVE:}

Art. $1^{\circ}$ - Aprovar a concessão do título de Doutora Honoris Causa à quebradeira de coco Dona Raimunda Gomes da Silva.

Art. $2^{\circ}$ - Esta resolução entra em vigor a partir desta data.

Palmas, 27 de maio de 2009

\author{
Prof. Alan Barbiero
}

Presidente 
ANEXO E: RESOLUÇÃO CONSUNI SISTEMA DE COTAS PARA QUILOMBOLAS

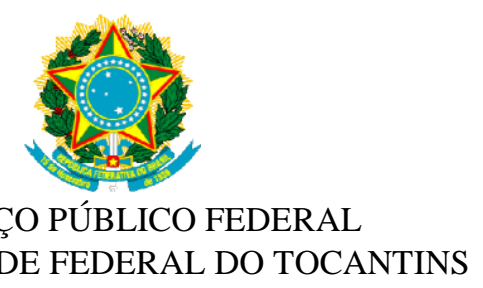

RESOLUÇÃO DO CONSELHO UNIVERSITÁRIO (CONSUNI)

N. ${ }^{\circ} 14 / 2013$

Dispõe sobre a implantação do sistema de cota para os quilombolas em todos os cursos de graduação da Universidade Federal do Tocantins.

O Egrégio Conselho Universitário - CONSUNI da Universidade Federal do Tocantins - UFT, reunido em sessão ordinária no dia 19 de novembro de 2013, no uso de suas atribuições legais e estatutárias, e CONSIDERANDO:

O art. 214 da Constituição Federal de 1988 que estabelece que o Plano Nacional de Educação tem como objetivo promover a articulação do Sistema Nacional de Educação em regime de colaboração como forma de assegurar a manutenção, desenvolvimento e universalização do ensino em seus diversos níveis, etapas e modalidades a todos;

Os termos das Leis $n^{\circ} 5.537 / 1968, n^{\circ} 9.394 / 1996 ; n^{\circ} 10.172 / 2012$ e, ainda as orientações da Portaria MEC n $389 / 2013$ que cria o Programa de Bolsa Permanência destinado a viabilizar a permanência, no curso de graduação, de estudantes indígenas e quilombolas;

Os dados do Censo de 2010 (IBGE, 2010) que atestam que 72,25\% da população do estado do Tocantins, aproximadamente 999.544 indivíduos (do total de 1.383 .445 habitantes do Estado), são predominantemente pardos e pretos;

Que há no estado do Tocantins 29 comunidades quilombolas certificadas pela Fundação Cultural Palmares e que outras 20 comunidades identificadas não foram ainda certificadas. E, que conforme dados do IBGE (2010), 37,62\% da população do Estado possuem idade entre 18 e 39 anos, o que representa uma população de 78.397 indivíduos negros, sendo que 37.325 destes possuem nível médio completo.

E, considerando ainda que a população rural do estado representa $21,1 \%$ do total e que as cidades que possuem população negra e quilombola possuem uma população rural maior que a média do Estado (a população negra rural do Estado é de aproximadamente 211.803 indivíduos);

RESOLVE:

Art. $1^{\circ}$. Aprovar a implantação do sistema de cota para os quilombolas em todos 
os cursos de graduação da Universidade Federal do Tocantins, a partir do $2^{\circ}$ semestre de 2014. $\S 1^{\circ}$. Fica estabelecido que será destinado aos estudantes quilombolas o percentual

de $5 \%$ (cinco por cento) do total das vagas em todos os cursos de graduação da UFT.

$\S 2^{\circ}$. Serão considerados remanescentes das comunidades dos quilombos, em

conformidade com o art. 2o do Decreto no 4.887, de 20 de novembro de 2003, os grupos étnicoraciais, segundo critérios de auto atribuição, com trajetória histórica própria, dotados de relações territoriais específicas, com presunção de ancestralidade negra relacionada com a resistência à opressão histórica sofrida.

Art. $2^{\circ}$. Esta Resolução entrará em vigor na data de sua publicação.

Palmas-TO, 19 de novembro de 2013.

Prof. Márcio Silveira

Presidente 


\title{
RESOLUÇÃO DO CONSELHO DE ENSINO, PESQUISA E EXTENSÃO- CONSEPE N ${ }^{\circ}$ AA/2004
}

\begin{abstract}
Aprova a implantação do sistema de cotas para estudantes indigenas no vestibular da Universidade Federal do Tocantins - UFT
\end{abstract}

O Conselho de Ensino, Pesquisa e Extensão - CONSEPE da Universidade Federal do Tocantins - UFT, no uso de suas atribuições legais e estatutárias, em sessão realizada no dia 03 de setembro de 2004, considerando o resultado de estudos elaborados pela Comissão Especial para Promoção de Políticas de Igualdade Racial, desta Instituição,

\section{RESOLVE:}

Art. $1^{\circ}$ - Aprovar a implantação do sistema de cotas para estudantes indigenas no vestibular da Universidade Federal do Tocantins - UFT.

$\S 1^{\circ}$ - Serão oferecidos aos estudantes indígenas $5 \%$ (cinco por cento) do total das vagas em todos os cursos e campi da UFT.

$\S 2^{\circ}$ - Terão direito a usufuirem do sistema de cotas os estudantes indigenas que apresentarem a documentação exiggida no edital do processo seletivo da UFT. (Redação dada pela Resolução n'10/2011 do Consepe)

Art. $2^{\circ}$ - Esta Resolução entrará em vigor na data de sua publicação.

Palmas, 03 de setembro de 2004

Prof. Alan Barbiero

Presidente 
ANEXO G: REGULAMENTAÇÃO DAS ATIVIDADES DO EXTENSIONISTA COLABORADOR NA UnB 


\section{UNIVERSIDADE DE BRASÍLIA}

RESOLUÇÃO DO CONSELHO DE ENSINO, PESQUISA E EXTENSÃO N. 146/2006

Regula as atividades de Extensionistas Colaboradores que, sem vínculo empregatício com a Fundação Universidade de Brasilia, participam de Projetos de Extensão de Ação Contínua na Universidade de Brasilia.

O PRESIDENTE DA FUNDAÇÃO, REITOR DA UNIVERSIDADE DE BRASÍLIA E PRESIDENTE DO CONSELHO DE ENSINO, PESQUISA E EXTENSÃO, no uso de suas atribuições, conforme deliberação do referido Órgão Colegiado em sua 404를 Reunião, realizada em 29/6/2006,

RESOLVE:

Art. 1- Fica criada, na Universidade de Brasilia, com as caracteristicas estabelecidas por esta Resolução, a categoria de Extensionista Colaborador.

Art. $2^{\circ}$ Extensionista Colaborador é aquele que integra a equipe de Projeto de Extensão de Ação Contínua cadastrado no Decanato de Extensão, avaliado pelo seu coordenador como de alto grau de produção na Extensão, consolidadá e objetivada em relatórios, publicações qualitativa e quantitativamente importantes.

Art. $3^{\circ}$ Aos Extensionistas Colaboradores são assegurados, pela Universidade de Brasília, direitos e prerrogativas tais como o acesso aos serviços regularmente oferecidos (Biblioteca, Restaurante e Centro Olímpico), bem como o patrocínio formal de suas atividades intelectuais, sem ônus para a FUB.

Art. $4^{\circ}$ Os candidatos a categoria de Extensionista Colaborador devem apresentar Plano de Trabalho acompanhado do Relatório do Coordenador do Projeto de Extensão Ação Contínua, que serão examinados pelo Departamento, em cujo âmbito suas atividades

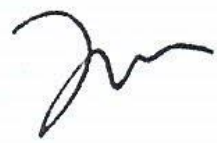




\section{UNIVERSIDADE DE BRASÍLIA}

se exercerão, pelo Conselho Departamental ou equivalente da Unidade, e pela Câmara de Extensão.

Art. $5^{\circ}$ O periodo de vigência do credenciamento é de até 2 (dois) anos, com aprovação de relatório de atividades e prorrogáveis mediante apresentação de novo Plano de Trabalho, conforme tramitação prevista no artigo $4^{\circ}$ desta Resolução.

Art. 6ำ As atividades inerentes à categoria criada por esta Resolução não implicarão em vínculo empregatício com a Fundação Universidade de Brasília, à míngua dos requisitos da subordinação jurídica e da onerosidade.

Art. $7^{\circ}$ Nas publicações dos resultados de trabalhos de extensão, realizados pelos Extensionistas Colaboradores na Universidade de Brasília, deve constar o crédito do vínculo com esta Instituição.

Art $8^{\circ} \quad$ Aos direitos e deveres relacionados as tecnologias desenvolvidas na Universidade de Brasilia, que gerem resultados passiveis de registro junto aos órgãos competentes, tais como patente de invenção, modelo de utilidade, desenho industrial, marca, registro de programas de computador, indicação geográfica, organismo geneticamente modificado e cultivar, aplica-se o disposto na Resolução do Conselho de Administração n. 005/98.

Art. 9ำ Esta Resolução entra em vigor na data de sua publicação.

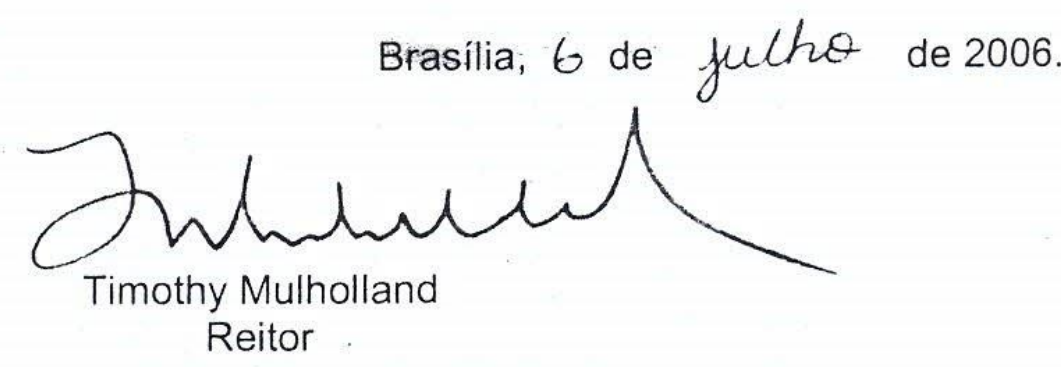




\section{APÊNDICE I: AS INSTÂNCIAS DO OLHAR}

INVENTARIAR, PESQUISAR

QUANTO MAIS PRÓXIMO AO QUE PESQUISA

MAIS FÁCIL É

E A PROXIMIDADE SE DÁ NO DIA A DIA NÃO NO ESPAÇO FÍSICO ENTRE DOIS CORPOS SE A PESQUISA CAMINHA, ENTÃO CAMINHO EU SE COME FARINHA, ENTÃO FARINHA COMO EU

O VALOR DO CHÃO É PRA QUEM PISA E BATE A ENXADA PRA SABER QUÃO DURO É FESTAS, CAMINHOS E BELEZAS

COMO SÃO REALMENTE

NÃO PARA PARECER BELO A UM DISTANTE PARENTE

(GUILHERME ALVES BARBOSA, 2008) 


\section{Dona Andrelina}

Figura 28: Produção de louças para os festejos de setembro de 2015

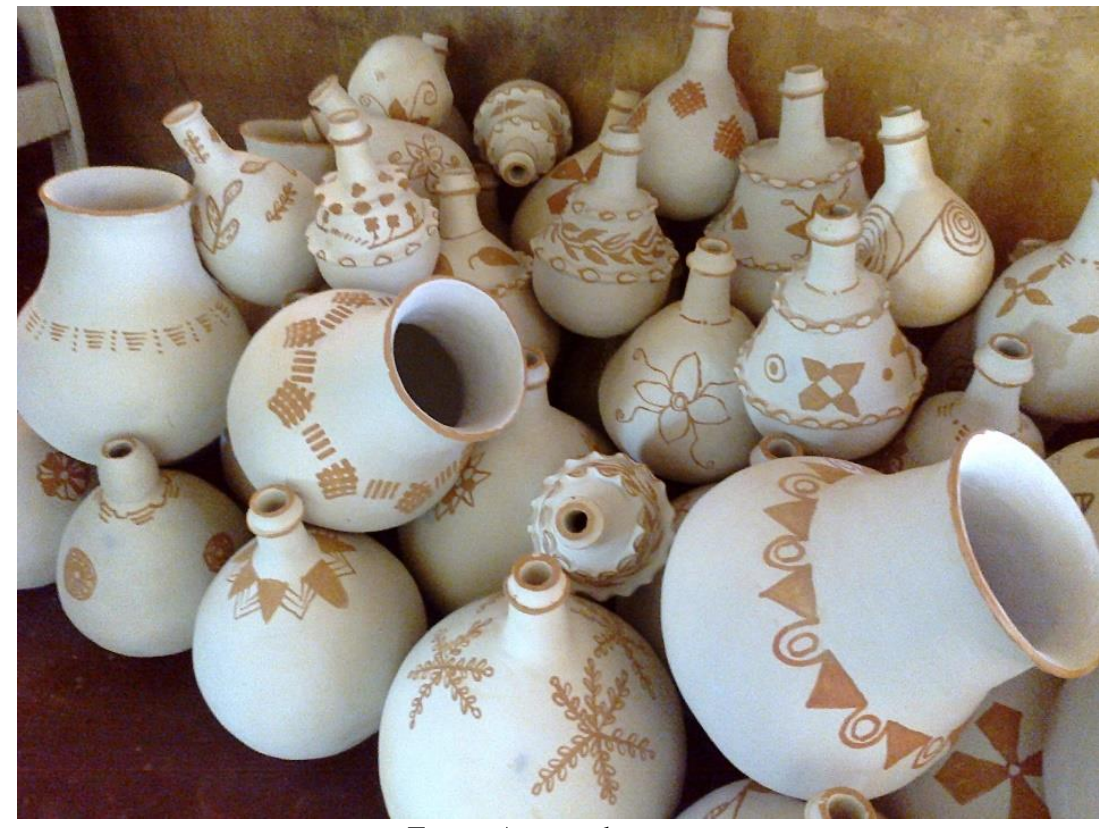

Fonte: Acervo da autora

Figura 29: Técnica de entrelaçamento em espiral na confecção das louças

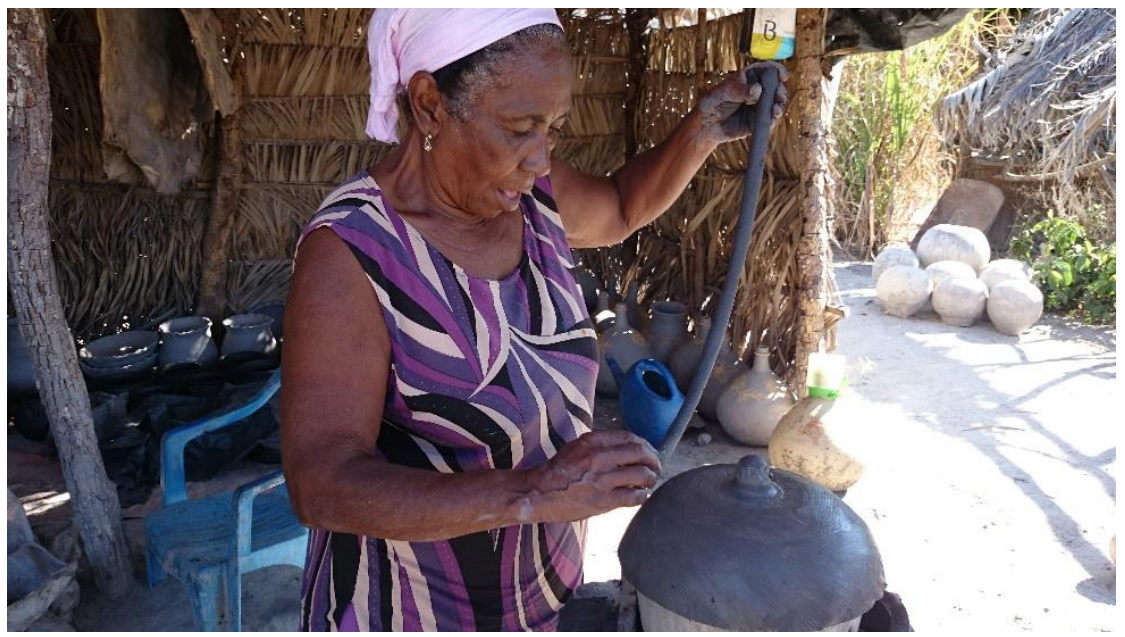

Fonte: Acervo da autora 
Figura 30: Dona Andrelina modelando uma botija

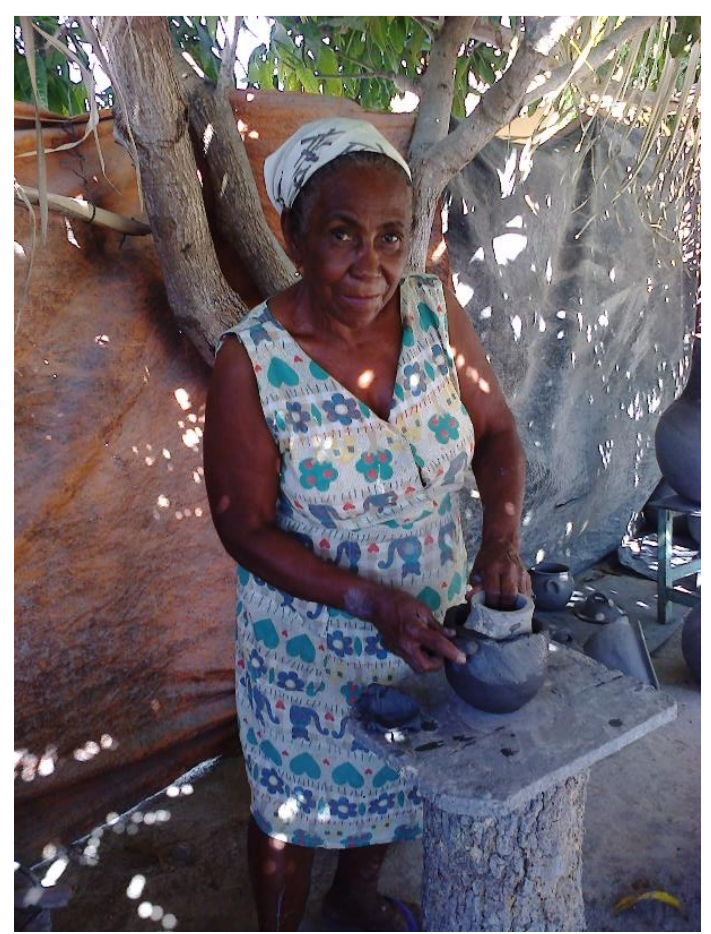

Fonte: Acervo da autora

Figura 31: Louças produzidas para os festejos de setembro de 2014

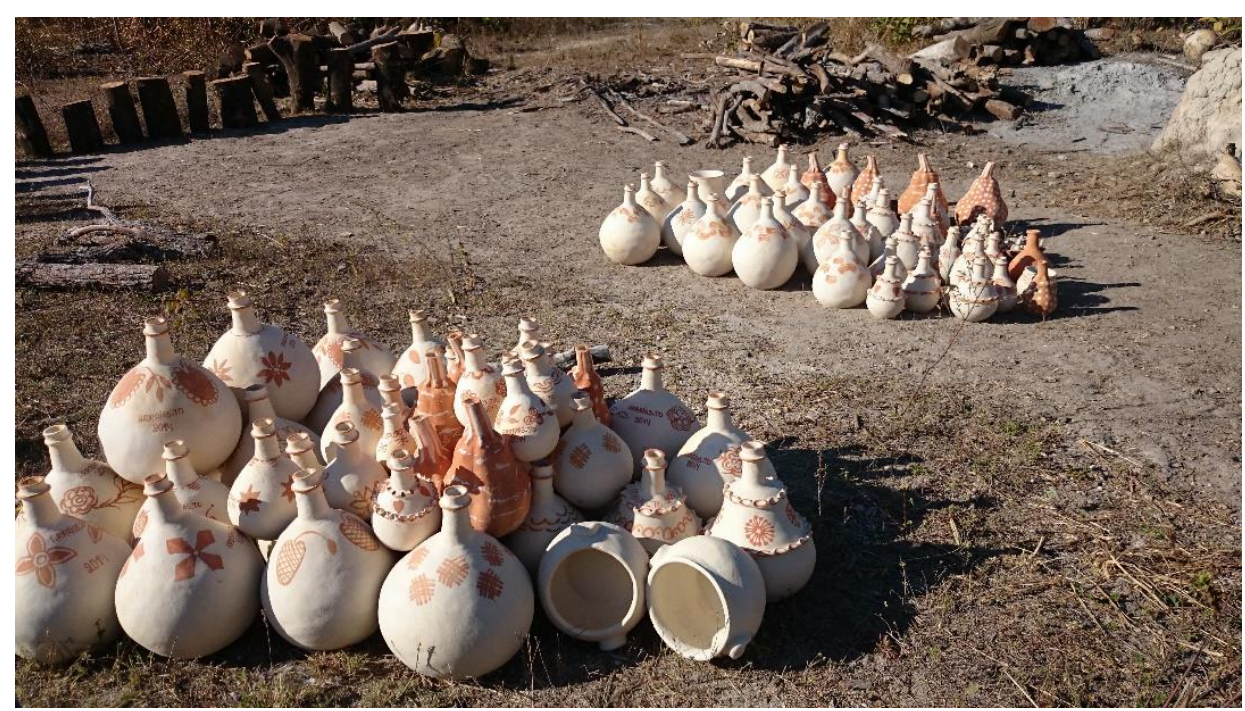

Fonte: Acervo da autora 


\section{Dona Pretinha}

Figura 32: Dona Pretinha usando o processo de enformar o pote

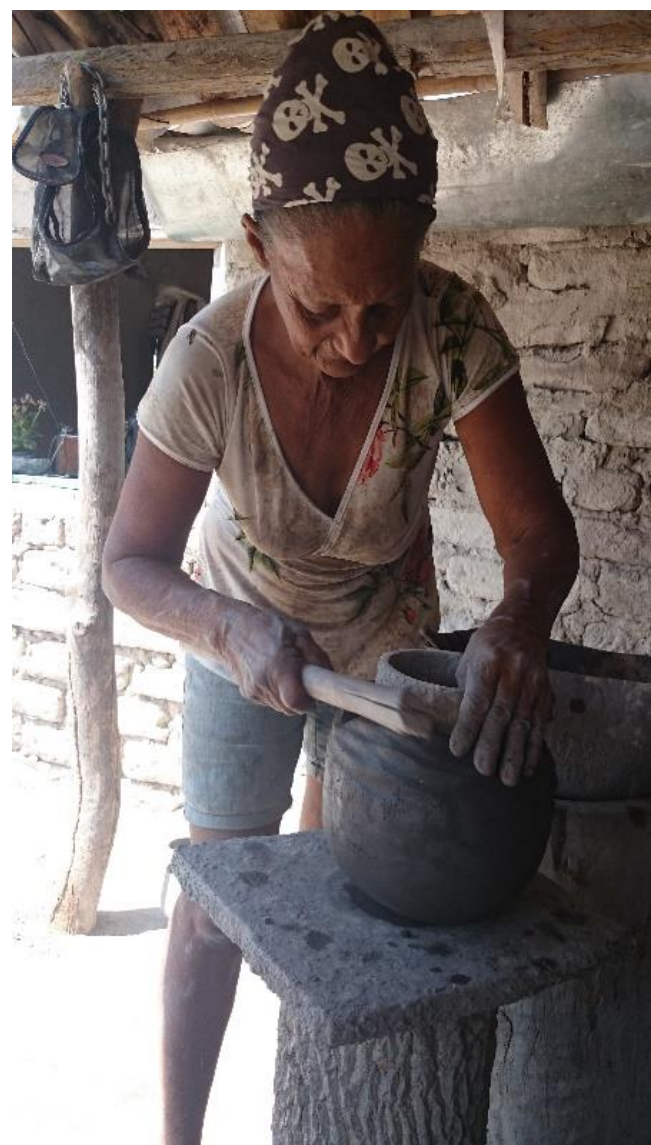

Fonte: Acervo da autora

Figura 33: Pintura com argila colorida utilizando os dedos

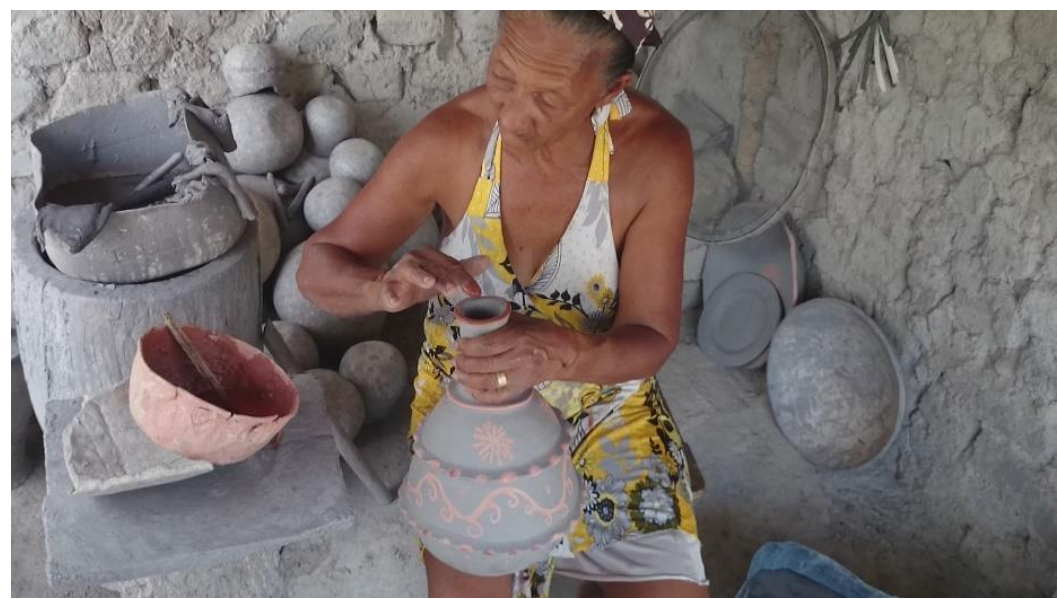

Fonte: Acervo da autora 
Figura 34: Residência de Dona Pretinha: Sítio Novo (zona rural de Arraias/TO)

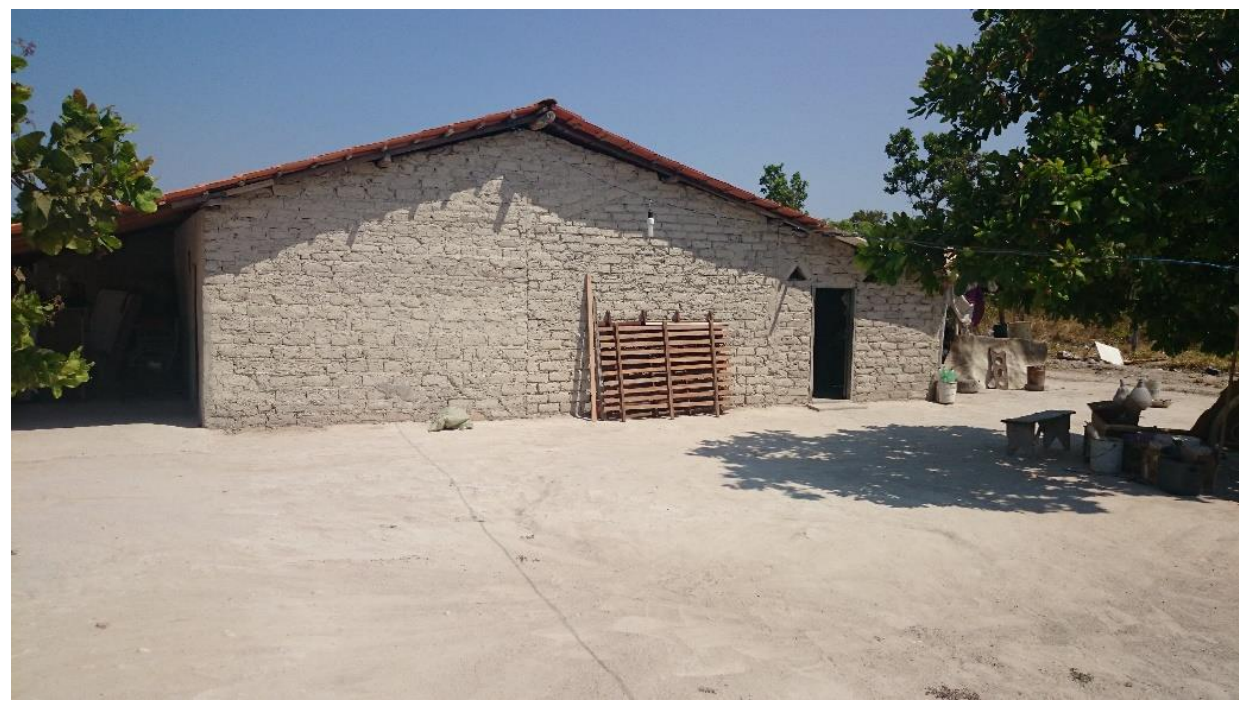

Fonte: Acervo da autora

Figura 35: Prateleira de madeira na rodovia TO 050

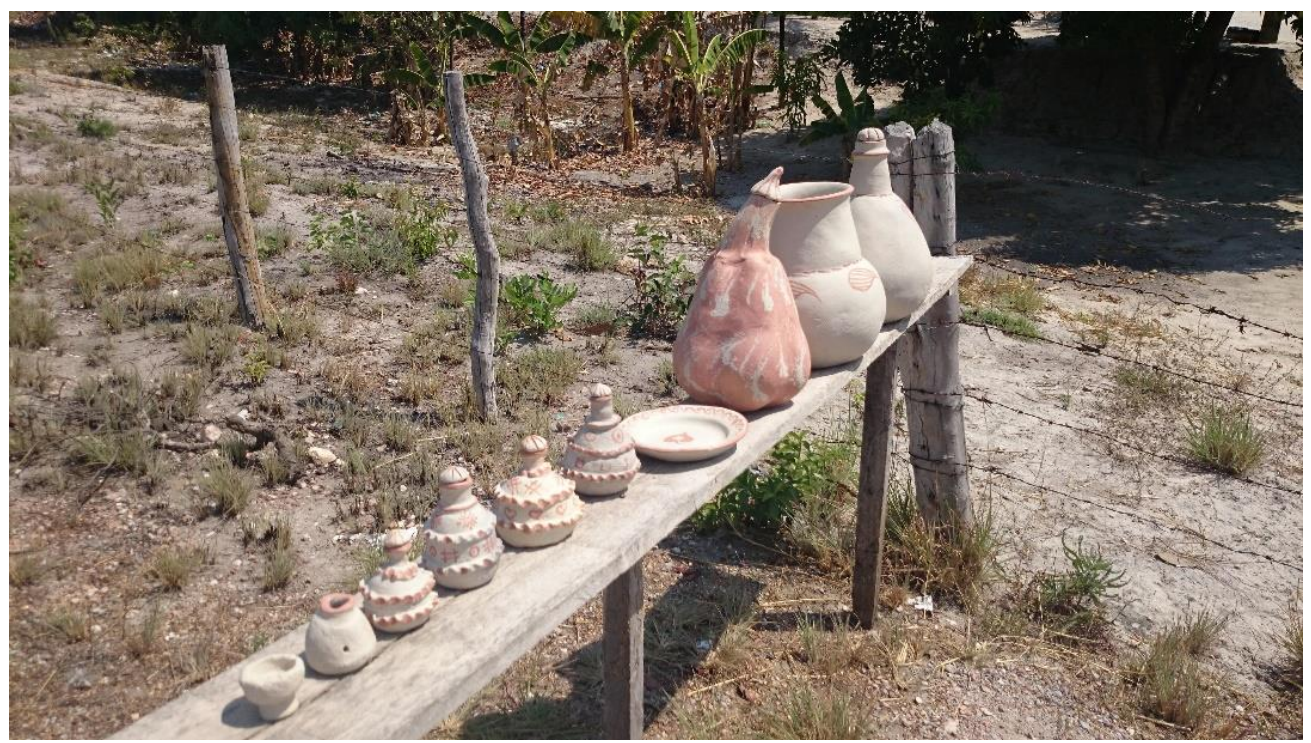

Fonte: Acervo da autora 
APÊNDICE II: EMENTA DE PROPOSTA DE DISCIPLINA 
Universidade Federal do Tocantins

Campus Universitário de Arraias

Curso de Licenciatura em Matemática

Disciplina: Etnomatemática em contextos socioculturais: conceituação da matemática da sensibilidade

Prof ${ }^{a}$ Alcione Marques Fernandes

Carga horária: $60 \mathrm{~h} / \mathrm{a}$

Ementa: bases teóricas da Etnomatemática, pesquisa de campo etnográfica na etnomatemática, a matemática desenvolvida por meio da sensibilidade, processos de abstração e criatividade em comunidades tradicionais, a matemática da simetria presente em ornamentos, o encontro dos distintos saberes.

Objetivos:

- Apresentar a área de pesquisa da Etnomatemática com breve incursão sobre seu desenvolvimento histórico;

- Estabelecer critérios para o desenvolvimento de pesquisa de campo etnomatemática e etnográfica.

- Estudar elementos presentes nos saberes e fazeres de comunidades que evidenciam a utilização da matemática da sensibilidade;

- Acompanhar processos de construção artísticas e/ou artesanais em grupos ou comunidades distintas;

- Desenvolver estudos de padrões de simetria presentes em ornamentos de artesanato produzidos por estas comunidades que possam dialogar com elementos da matemática acadêmica;

- Organizar atividades que promovam o encontro entre os saberes da matemática acadêmica e a matemática da sensibilidade.

Metodologia: a disciplina será desenvolvida a partir da leitura e da discussão de textos relevantes na área da Etnomatemática, realização de pesquisas de campo em comunidades e/ou grupos específicos, organização e apresentação de seminários a partir de propostas de estudo sobre os conceitos matemáticos envolvidos nas pesquisas etnomatemática e etnográfica, investigação das técnicas utilizadas nas comunidades envolvendo seus saberes e fazeres, estudo de padrões de simetria dos ornamentos produzidos pelas comunidades pesquisadas, busca de estratégias que viabilizem o diálogo entre a matemática formal e a matemática desenvolvida pelo grupo pesquisado, por meio da matemática da sensibilidade.

Avaliação: A avaliação da disciplina acontecerá a partir da apreciação do resultado final do projeto desenvolvido pelo aluno(a) considerando sua fundamentação etnomatemática, sua criatividade e a capacidade de estabelecer pontes entre a matemática formal e os saberes matemáticos culturais.

Referências: vide tese. 